$$
\begin{gathered}
\text { Universidade de São Paulo } \\
\text { Departamento de Letras Clássicas e Vernáculas }
\end{gathered}
$$

Programa de Literatura Brasileira

Mariana Carlos Maria Neto

\title{
A FALTA E O MAR ABSOLUTO EM CECÍLIA MEIRELES (VERSÃO CORRIGIDA)
}

Dissertação

São Paulo 2018 
Mariana Carlos Maria Neto

\section{A falta e o mar absoluto em Cecília Meireles (VERSÃO CORRIGIDA)}

Dissertação apresentada ao Programa de PósGraduação em Literatura Brasileira, da Universidade de São Paulo como requisito para obtenção do título de Mestre.

Orientador: Prof. Dr. Murilo Marcondes de Moura

São Paulo

Março 2018 
Autorizo a reprodução e divulgação total ou parcial deste trabalho, por qualquer meio convencional ou eletrônico, para fins de estudo e pesquisa, desde que citada a fonte.

Catalogação na Publicação

Serviço de Biblioteca e Documentação

Faculdade de Filosofia, Letras e Ciências Humanas da Universidade de São Paulo

\begin{tabular}{|c|c|}
\hline M469f & $\begin{array}{l}\text { Maria Neto, Mariana } \\
\text { A falta e o mar absoluto em Cecília Meireles / Mariana } \\
\text { Maria Neto ; orientador Murilo Marcondes de Moura. - } \\
\text { São Paulo, } 2018 \text {. } \\
\quad 124 \mathrm{f} .\end{array}$ \\
\hline & $\begin{array}{l}\text { Dissertação (Mestrado) - Faculdade de Filosofia, } \\
\text { Letras e Ciências Humanas da Universidade de São } \\
\text { Paulo. Departamento de Letras Clássicas e } \\
\text { Vernáculas. Área de concentração: Literatura } \\
\text { Brasileira. }\end{array}$ \\
\hline & $\begin{array}{l}\text { 1. Literatura Brasileira. 2. Poesia. 3. Cecília } \\
\text { Meireles. I. Marcondes de Moura, Murilo, orient. II. } \\
\text { Título. }\end{array}$ \\
\hline
\end{tabular}




\section{Folha de aprovação}

Defesa da dissertação de mestrado de Mariana Carlos Maria Neto, intitulada: "A falta e o mar absoluto em Cecília Meireles", orientada pelo Prof. Dr. Murilo Marcondes de Moura e apresentada ao Programa de Pós-Graduação em Literatura Brasileira do Departamento de Letras Clássicas e Vernáculas, da Universidade de São Paulo, para obtenção do título de Mestre em Literatura Brasileira.

Os membros da Banca Examinadora consideraram o(a) candidato(a)

Banca Examinadora:

(Assinatura)

(Titulação/nome/instituição)

(Assinatura)

(Titulação/nome/instituição)

(Assinatura)

(Titulação/nome/instituição)

(Assinatura)

(Titulação/nome/instituição) 


\section{Agradecimentos}

Caberiam muitos nomes nesta lista de agradecimentos, entretanto, o que apresento é uma pequena amostra daqueles que direta ou indiretamente me auxiliaram para a realização desse projeto:

à CAPES, pelo financiamento imprescindível;

ao meu orientador, Murilo Marcondes de Moura. Homem de uma inteligência refinadíssima, com quem só aprendo;

a Leila Gouvêa e Fernando Paixão, que na banca de qualificação fizeram uma arguição cuidadosa e estimulante;

ao meu pai, Cássio Maria Neto, que um dia me disse: "Seus sonhos são meus sonhos". Aí está nosso mestrado, pai;

à minha mãe, Marilda Mestre Carlos, por sempre ter me ensinado a seguir em frente, mesmo quando desse medo;

à Aline Novais de Almeida, companheira de programa e da vida também.

ao Augusto, Guto, amigo, com quem vou da varanda à lua. Por todas as leituras, pelas madrugadas (com ou sem livros), pela vida que dividimos;

à Augusta, Gutinha, por tanta leveza, pela amizade sempre honesta;

ao Bruno Mancini, cujo incentivo, no início dessa trajetória, foi fundamental. Tudo nesse texto é também um pouco seu;

a Celina e Márcio, companheiros de trajetória, amizade para a vida toda;

ao Fábio Passoni Martins e Marcos Alconchel, que foram fundamentais durante o processo seletivo;

ao Herón, que chegou de longe, mesmo tendo sido sempre de perto;

à Lívia, pela amizade nova e tão cheia de vida;

à Márcia Marina, minha amada amiga, pela leitura dos primeiros poemas e, eu sei, até os últimos;

à Marina, Adriano, Fernando e Laurinha, por terem me presenteado com livros e por acreditarem que eu cuidaria bem desse pedacinho do Fábio;

à Mayara Carlos Maria Neto, minha irmã, com quem dividi as belezas da infância;

ao Alessandro, amigo de sorriso fiel, lá do 501;

à Silvia Helena, pela leitura gentil;

à Vivian Lopes: "Meu coração cresce dez metros e explode. $\$ - Ó vida futura! Nós te criaremos.

"Por toda leitura e por esse mundo novo pelo qual lutamos; 
ao Wendel Santos, meu encontro de sorte. De quem quero ser eternamente vizinha de porta;

aos amigos do plantão do Poliedro, em especial, à Letícia e ao Gabriel. Por tanto auxiliarem, seja ouvindo, seja ajeitando os horários. Obrigada por acreditarem no meu trabalho;

ao Renan, meu Renanzinho. Fora de toda a ordem alfabética, que nas curvas da vida apareceu e ficou. Com quem tropeço, com quem me levanto. Meu melhor riso, minha melhor companhia. Meu amor. Por tudo que não cabe nesse agradecimento. 


\title{
RESUMO
}

Este trabalho propõe-se a analisar Mar absoluto e outros poemas (1945), de Cecília Meireles (1901-1964). A unidade da seleção dos poemas vem por meio da recorrência de um sentimento da falta, assunto constante na lírica ceciliana e muito representativo em sua terceira obra da poesia madura. Pretende-se pensar a totalidade da produção poética da autora, relacionando-a a obra estudada. São lidos os poemas: "Irrealidade", "Mar absoluto" e "Elegia", em cada um deles vê-se, ao mesmo tempo, uma falta fundante e um desejo de encontro. A síntese entre esses dois polos produz um absoluto que conjuga distância e proximidade, ausência e afeto.

Palavras- chave: Cecília Meireles, poesia, falta, absoluto, Mar absoluto e outros poemas.

\begin{abstract}
This paper aims to analyze Mar absoluto e outros poemas, by Cecília Meireles. What brings together the poems that are part of the book is the theme of absence, which is a recurrent subject in Meirele's lyric and clearly depictive in her third work of mature poetry. The objective was to think the totality of the author's poetic production, relating it to the book studied here. We discuss the poems: Irrealidade, Mar absoluto and Elegia. In which one of them, we see, simultaneously, a founding absence and the wish for encounter. The synthesis between these two poles creates an absolute realm that unites distance and proximity, absence and affection.
\end{abstract}

Keywords: Cecília Meireles, poetry, absence, absolute, Mar absolute e outros poemas. 


\section{Sumário}

Apresentação.................................................................................................... 8

Capítulo 1 - Distância e afeto................................................................. 22

1.1 Eu sou criatura de longe. .......................................22

$1.2 \mathrm{O}$ que se ganha no longe? .....................................41

Capítulo 2 - A morte abstrata e o amor concreto................................. 47

2.1 A recordação - o mar................................................50

2.2 O motivo - a família................................................55

2.3 Eu, Eles, Nós - o nosso mar..................................62

2.4 Conhecendo o mar - o caminho de contrários......66

2.5 Búzios da lembrança - o novo trajeto.....................71

2.6 O outro mar - nas voltas do Absoluto....................76

2.7 A procura do vazio...................................................78

Capítulo 3 - A morte concreta e o amor cotidiano...................................83

3.1 "Tudo em ti era uma ausência que se demorava"..83

3.2 A morte...............................................................92

3.3 A escolha do gênero elegíaco....................................95

3.4 "Faltam teus olhos como ilhas, mares, viagens"....97

3.4 A falta e o absoluto................................................114

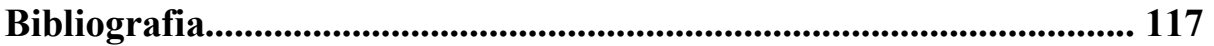


Para Laura, Cleide e Marilda: amor que caminha comigo. 


\section{APRESENTAÇÃO}

\section{Este trabalho}

Este trabalho é essencialmente analítico, o que significa que a partida de toda a reflexão desenvolvida no texto são os poemas e a poesia de Cecília Meireles. Nosso esforço primeiro foi visualizar e tentar compreender o imaginário que organizava seus versos, sempre tendo em mente o todo da poesia da autora. O desejo de totalidade é importante para evitar deslizes em relação ao próprio percurso de uma poesia, mas também pode desviar a atenção do particular, das especificidades do estilo e da palavra poética de cada autor. Nesse sentido, nos direcionamos para sua terceira obra da maturidade: Mar absoluto e outros poemas, de 1945, cujo título faz ver um dos mais importantes símbolos da poesia ceciliana em formato pleno, totalizante. Selecionei dessa obra três poemas que serão lidos nos três capítulos que compõem essa dissertação.

A apresentação que segue abaixo nasceu do contorno que foi aos poucos se impondo ao trabalho. Durante a leitura e releitura da obra completa e da bibliografia crítica, notamos que havia uma unidade que funcionava como polo propulsor da poesia, a qual chamamos de falta. Nessa introdução pretendemos explicar essa unidade e desmembrar seus possíveis significados na poética da autora e mais especificamente em Mar absoluto e outros poemas. Cabe ainda dizer que o formato desse trabalho exige uma leitura global, pois os capítulos se interdependem e respondem uns aos outros. Seu sentido possível, então, nasce do acúmulo das partes que o compõem.

Apesar de ter comparado, nos poemas analisados, algumas diferentes edições; assumimos a da Obra poética de 1958, por ser essa a única e última edição da poesia completa publicada em vida da autora.

\section{Da falta}

Cecília Meireles consagrou-se como poeta com a premiação de Viagem, em 1938, concedida pela Academia Brasileira de Letras, o que lhe trouxe certo prestígio (não só pela vitória, mas também por ser a primeira mulher a receber tal premiação) e o reconhecimento de 
homens ilustres da época. Contudo sua vitória trouxe consigo alguma polêmica ${ }^{1}$, na Academia e também na imprensa, uma vez que Cassiano Ricardo pretendia atribuir um prêmio único à poeta, dada a qualidade de Viagem diante dos demais concorrentes.

Decisão que causa furor não só à imprensa, como ao acadêmico-médico Fernando de Magalhães. A notícia ganha espaços nos jornais. O jornal nazista "Meio-Dia" publica uma reportagem com o título "Inconvenientes os Versos da Poetisa Cecília Meireles". A celeuma foi até mesmo estampada nas páginas da "Gazeta Policial". ${ }^{2}$

Censurada em seu discurso, Cecília se recusa a lê-lo durante a premiação. A controvérsia chama a atenção de Mário de Andrade que escreve, em 1939, no Diário de Notícias, o ensaio "Viagem", apoiando a vitória de Cecília e enaltecendo em sua poesia uma "rara independência", capaz de escolher "de todas as tendências apenas o que enriquece ou facilita a expressão do ser". ${ }^{3}$ Todo o debate em torno de sua premiação já iluminava, de alguma forma, o lugar que a poeta ocuparia em nossas letras, sempre algo deslocada. Como sabemos, Cecília nunca se alinhou ao modernismo paulista tampouco manteve a proximidade do grupo carioca de $A$ festa, de tal maneira que seus projetos poéticos sempre preservaram uma perspectiva bastante própria. O que Manuel Bandeira acertadamente pontua em "Improviso" 4.

Cecília, és libérrima e exata

Como a concha.

Mas a concha é excessiva matéria,

E a matéria mata.

Cecília, és tão forte e tão frágil

Como a onda ao termo da luta.

Mas a onda é água que afoga:

$\mathrm{Tu}$, não, és enxuta.

Cecília, és, como o ar,

Diáfana, diáfana.

Mas o ar tem limites:

Tu, quem te pode limitar?

[...]

${ }^{1}$ No plano biográfico, apesar de toda contenda, o prêmio talvez tenha sido como um alento para a poeta, que em 1935 encerrara, com suicídio de seu primeiro marido Fernando Correia Dias, a sequência de mortes que modelaram sua vida.

${ }^{2}$ Valéria Lamego. "Intrigas políticas". Folha de São Paulo, 04/08/1996. Disponível em: http://www1.folha.uol.com.br/fsp/1996/8/04/mais!/10.html

${ }^{3}$ Marina Damasceno de Sá. "Edição de texto fiel e anotado d' O empalhador de passarinho de Mário de Andrade". Vol. II. Dissertação (Mestrado em Literatura Brasileira - USP), São Paulo, 2013. p. 275.

${ }^{4}$ Manuel Bandeira. "Improviso", in Estrela da vida inteira. Nova Fronteira, Rio de Janeiro, 2009. P. 194. 
A delicadeza dos versos bandeirianos retomam muito do tom da poesia de Cecília e são precisos sobre a expressão da poeta: "libérrima e exata". Essa dimensão da liberdade, presente na crítica de Mário de Andrade e no poema de Bandeira, destaca uma poesia extremamente fiel a si mesma, que busca na tradição da literatura os recursos que a auxiliam na realização desse projeto poético, sem se atrelar (num sentido estético e político) a nenhuma delas. Essa característica poderia, numa visão panorâmica, fazer com que entendamos a poesia de Cecília Meireles como "um todo uniforme e linear" 5 . Contudo, essa uniformidade não será defeito estético na lírica ceciliana, que aposta em "representar não as rupturas, mas as permanências" 6. Talvez a sensibilidade moderna julgue monótono o repetir-se em torno da morte sempre certa ou da eterna navegação que constitui a vida humana, mas ao imaginário ceciliano, esse repetirse reafirma um lirismo que resiste à fragmentação e acredita na "consistência própria e resistente do espírito" 7 .

É por isso que esses poetas da abstração lírica parecem sempre tão iguais a si mesmos, e é tão insignificante querer analisá-los e compreendê-los tematicamente. Os temas, como tal, são muito poucos, tão poucos como a bagagem metafórica. E tanto os temas como as metáforas devem ser compreendidas, não pelo que parecem ser, mas como pretextos que o poeta usa, um Instrumental convencional (uma cifra pessoal) para fixar o que não é dizível $[\ldots]^{8}$

A poesia de Cecília se fecha nesse grande destino de si mesma e por isso, "os textos se entrelaçam, os livros parecem sair uns dos outros, trechos de poemas reaparecem com sutis variações, os temas voltam na prosa, nos ensaios e entrevistas [...]" ${ }^{9}$. Tanto retorno é certamente admirável para uma poeta que escreveu muito (ao todo são vinte e sete obras, só de poesia) e que se representou como eterna viajante. Na repetição dos temas, a poesia ceciliana assume uma feição de permanência, alinhando-se a um mesmo sentido, ou a um grande pretexto (como quis Jorge de Sena), cuja síntese é feita por Darcy Damasceno:

A consideração das coisas resulta na consciência de que a vida é um fluxo constante e o tempo a tudo corrói; a constatação da transitoriedade emerge como o verme antecipador do podre que um dia há de ser apetecível fruto da vida. Daí que às descargas dos sentidos se sobreponha a indagação, a análise, a atitude inteligente. ${ }^{10}$

\footnotetext{
${ }^{5}$ Antonio Candido e José Aderaldo Castelo. Presença da literatura brasileira: história e crítica. Editora Bertrand Brasil, 1997. 10ed. p. 136

${ }^{6}$ Alcides Villaça. "Sobre Cecília em Portugal". In GOUVÊA, Leila. Cecília em Portugal. São Paulo: Iluminuras, 2001p. 13

${ }^{7}$ Idem. Ibidem. p. 13

${ }^{8}$ Jorge de Sena. Cecília Meireles ou os puros espíritos". Suplemento Literário, Diário de São Paulo em 20/02/1965. p.4.

${ }^{9}$ Miriam Silvia Schuartz. O avesso do poema: Cecília Meireles e a metamorfose. Editora Scortecci, 2010. p. 25.

${ }^{10}$ Darcy Damasceno. "Poesia do sensível e do imaginário". In Cecília Meireles. Obra poética. "Editora José Aguilar, Rio de Janeiro, 1958. p. XXXV.
} 
Os olhos de Cecília, como explica o crítico, voltam-se para o mundo já antevendo nele a negatividade que o constitui. A poesia nasce, então, de um esforço da inteligência em pensar a mortalidade e a precariedade da vida humana, sob a perspectiva do tempo. Daí a necessidade de metrificação, dos temas mais clássicos da lírica, do sempre apelo à imortalidade do poema e de seus objetos. Veremos, portanto, que todos os motivos fundamentais dessa lírica se expressam como formas de uma ausência ou de uma falta, colocada na relação consigo mesma ou com o mundo. A morte, a viagem, a navegação, a memória, os retratos, o pasmo diante da passagem do tempo, a solidão, a família, os mortos e o irreal, figuram essa falta. E o sujeito lírico ao se deparar com essa negatividade reage a ela pela via da indagação, de tal maneira que apesar da consciência da falta ser profunda, é também impulso para o cantar.

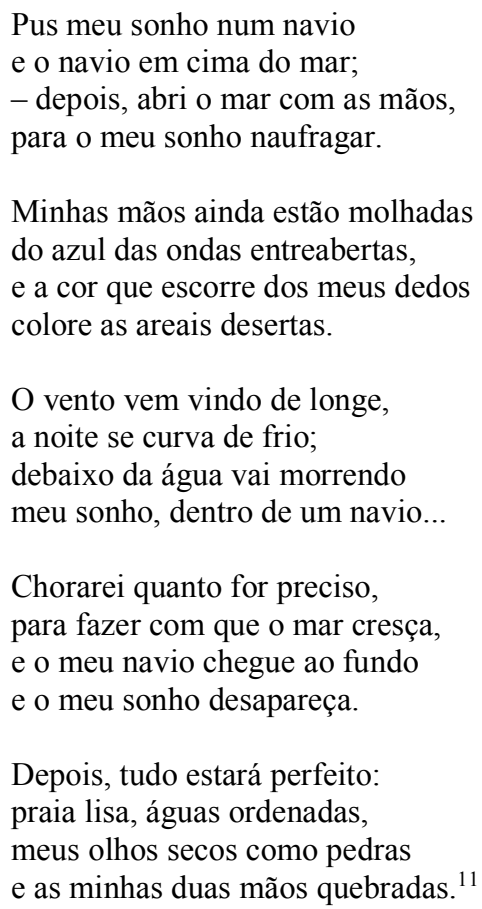

"Canção" ajuda a ilustrar essa condição negativa da poeta, já que o poema nasce do naufrágio, ou do sufocamento, de um sonho. A poeta forja uma falta para que o poema aconteça e seu empenho em fazer com que o "sonho desapareça" resulta na "praia lisa" e nas "ondas ordenadas". Apesar do assunto denso, o poema mantém seu ritmo garantido pela regularidade métrica e pelas rimas nos segundos e quartos versos de cada estrofe, tanto que a negatividade do assunto não abala a melodia da canção. A decisão pela falta (a morte do sonho) garante ao

${ }^{11}$ Cecília Meireles. Obra poética. “Canção”, (Viagem). Editora José Aguilar, Rio de Janeiro, 1958. p. 18. 
poema a mesma ordenação da praia e o sujeito lírico, optando por se afastar de questões confessionais, constrói um lirismo calcado numa ausência de si e numa falta fundante que motiva todo o cantar. Menotti Del Picchia ${ }^{12}$ falará em "anverso do eu", Paulo Rónai ${ }^{13}$ em "poesia impessoal". De todo o modo, o fenômeno é o mesmo: a ausência que a poeta imprime como condição da poesia:

\begin{abstract}
Minha infância de menina sozinha deu-me duas coisas que parecem negativas, e foram sempre positivas para mim: silêncio e solidão. Essa foi sempre a área da minha vida. Área mágica, onde caleidoscópios inventaram fabulosos mundos geométricos, onde os relógios revelaram o segredo do seu mecanismo, e as bonecas o jogo do seu olhar. Mais tarde, foi nessa mesma área que os livros se abriram, e deixaram sair suas realidades e seus sonhos, [...] Foi ainda nessa área que apareceram um dia os meus próprios livros, que não são mais do que o desenrolar de uma vida encantada com todas as coisas, e mergulhada em solidão e silêncio tanto quanto possível. ${ }^{14}$
\end{abstract}

A negatividade, que chamamos nesse trabalho de falta, não é algo simples na poesia ceciliana, já que ela é como um filtro na relação do sujeito com o mundo. Como mostra o trecho transcrito acima, o silêncio e a solidão constroem o lugar do qual a menina e depois a poeta veem a vida e se encantam por ela. Em Viagem, essa perspectiva será ainda magoada e melancólica, mas no decorrer dos livros profundamente ressignificada. Por isso quando Darcy Damasceno formula: "Nessa posição final da inteligência frente ao mundo, educa-se o artista na renúncia, no desprendimento e no amor" ${ }^{15}$, deveríamos subordinar o amor à renúncia e ao desprendimento (formas negativas), sendo que só a partir deles a poeta consegue alcançar aquele. É desse lugar de ausência que nascem os poemas e os livros de Cecília Meireles.

Se pensarmos no percurso cronológico das obras, veremos que, em Viagem, essa falta se expressa na ausência de um $t u$, para quem o eu-lírico canta e de quem nunca recebe resposta; num esforço de apagamento de si (como pudemos ver em "Canção") e numa atitude profundamente melancólica que sente a negatividade e se paralisa diante dela, aceitando-a de uma maneira bastante dolorida. Já em Vaga Música (1942), o fardo dessa negatividade diminui e a canção vai se impondo à tristeza. Entretanto, o abrandamento da dor não significará superação da falta:

\title{
$[\ldots]$
}

\footnotetext{
${ }^{12}$ Menotti Del Picchia. “Sobre Vaga Música”. In Cecília Meireles. “Fortuna Crítica”, Obra poética. Editora José Aguilar, Rio de Janeiro, 1958.p. LV.

${ }^{13}$ Paulo Rónai. "Mar absoluto". In idem. p. LXIV.

${ }^{14}$ Cecília Meireles. "Notícia biográfica". In Cecília Meireles. Obra poética. Editora José Aguilar, Rio de Janeiro, 1958. P.LXXII-LXXIII

${ }^{15}$ Darcy Damasceno. "Poesia do sensível e do imaginário". In Idem. p. XLII.
} 
Deus não fala comigo - e eu sei que me conhece.

A antigos ventos dei as lágrimas que tinha.

A estrela sobe, a estrela desce...

- espero minha própria vinda.

(Navego pela memória

sem margens.

Alguém conta a minha história

e alguém mata os personagens.).$^{16}$

$[\ldots]$

As lágrimas forçadas de "Canção" já foram dadas em "Explicação", o tom do poema é mais leve e podemos sentir que a poeta quase que sorri diante de seu mau destino. Entretanto, essa suavização não deve nos fazer pensar que temos, de um livro ao outro, mudanças bruscas. Pelo contrário, o que encontramos são pequenas variações que retratam os movimentos da inteligência em relação à falta percebida no mundo, nos outros e em si. Além disso, esse fenômeno não é linear ou mesmo figura algo da ordem do progresso. Solombra (1964), publicado pouco antes da morte da autora, é de uma profunda e definitiva negatividade. Os poemas, mais sisudos, e a falta são percebidos com seriedade, totalmente sem mágoa, possibilidade de riso ou de encontro. Nos 28 decassílabos brancos que compõem o livro, encontramos uma atitude altiva e intelectual, a recusa das rimas talvez ilumine esse desejo de não se derramar no encanto rápido do ritmo. No plano imagético, vemos sobreporem-se as imagens do vazio, guiadas por um movimento contínuo que culmina também em mais vazio.

Isto que vou cantando é já levado pelos rios do assombro, que entre as pálpebras das margens deixa apenas flores líquidas.

Longe descansará meu rosto agora.

Campos de ausência cobrirão seu límpido mutismo de certezas invioláveis.

Crescem bosques, escondem-se caminhos; as asas pressurosas dos crepúsculos não deixam a nitidez sequer nas lágrimas.

Ah, glória das palavras restituídas a seu mistério de alma, íntimo e cálido! Superfície de adeuses, mãos vazias.

Noite entretida com o som dos túmulos. ${ }^{17}$

${ }^{16}$ Cecília Meireles. "Explicação". Idem. (Vaga Música). p. 242.

${ }^{17}$ Cecília Meireles. "Isto que vou sendo é já levado", Poesia completa Vol.II. (Solombra). Org. Antonio Carlos Secchin. Nova Fronteira, Rio de Janeiro, 2001. p. 1274. 
Nos “campos de ausência”, a poesia de Cecília repousa. Dessa distância pode nascer um poderoso mar absoluto capaz de engolir a falta que o motiva ou um rio de assombro, que liquefaz tudo por onde passa. As respostas que a lírica ceciliana dá à falta são variadas e não seguem um percurso único; contudo, a indagação persiste e vai encontrando suas possibilidades na história, na imaginação e na poesia.

Tamanha procura vai se configurar como destino. E cada obra será uma faceta dessa busca e de seus descobrimentos.

\section{Mar absoluto e outros poemas}

Deus te proteja, Cecília, que tudo é mar - e mais nada..$^{18}$

Mar absoluto e outros poemas tem algumas especificidades importantes em relação ao tema de nosso trabalho, uma vez que nessa obra, a falta será sistematicamente encarada como uma totalidade. Acreditamos que haja nas três primeiras obras da poesia madura de Cecília Meireles um inchaço desse sentimento da falta, que vai ganhando corpo e assume a forma de um mar absoluto. Como já comentamos acima, há um alívio progressivo da dor e da melancolia entre as duas primeiras obras da fase madura de Cecília Meireles. Esse movimento assumirá, na obra seguinte, um sentido balsâmico, uma vez que a falta que motiva a canção não se oferecerá como uma negatividade absoluta (o que título poderia sugerir), mas sim, como um caminho de desafogo para o espírito.

Numa leitura comparativa, o leitor confirmará que os temas caros a Viagem e Vaga Música retornam em Mar absoluto e outros poemas, contudo, agora, assumindo uma feição totalizante. A falta que anteriormente se centrava nos assuntos da vida íntima da poeta, passa a expressar-se como constituidora de todas as coisas. Apesar de nunca ter abandonado a vocação melancólica de sua poesia, cujos exemplos são vastíssimos em todas as suas obras, em Mar absoluto e outros poemas, Cecília procura por essa unidade acolhedora, que curiosamente virá através da falta.

Nesse movimento dialético, veremos que a negatividade e o desejo pelo absoluto funcionam como pares para a construção de uma falta "positiva". Talvez o melhor exemplo disso seja o " $4^{\circ}$ Motivo da Rosa", que não só ilustra a questão como também ilumina o sentimento que compõe a obra.

\footnotetext{
${ }^{18}$ Cecília Meireles. "Beira-mar”. Idem. (Mar absoluto e outros poemas). p. 339.
} 
Não te aflijas com a pétala que voa:

também é ser, deixar de ser assim.

Rosas verás, só de cinza franzida,

mortas intactas pelo teu jardim.

Eu deixo aroma até nos meus espinhos,

ao longe, o vento vai falando em mim.

E por perder-me é que me vão lembrando, por desfolhar-me é que não tenho fim. ${ }^{19}$

No $4^{\circ}$ motivo ${ }^{20}$, pensamos ser a rosa quem fala à poeta, do primeiro ao último verso. $\mathrm{O}$ consolo inicial ("Não te aflijas com a pétala que voa”) está, portanto, direcionado para Cecília, sempre tão atenta e tão pouco conformada com o fluir finito da vida. Nos três primeiros motivos, vimos a rosa ser exaltada por sua beleza e a poesia por sua capacidade de eternizá-la, contudo, os motivos têm a particularidade de retratarem também a passagem do tempo. Cada um dos cinco está distribuído de forma regular na primeira parte de Mar absoluto e outros poemas, retornando, durante a leitura, sempre como uma espécie de eco. Um novo retorno, um novo olhar da poeta para a rosa. Em sua quarta aparição, a rosa já não está vigorosa como antes e nota no olhar de quem a vê a angústia do fim. No entanto, a afirmação da falta ("perder-me", "desfolhar-me"), torna-se uma fórmula de superação da mesma. O que fica expresso pelos versos: "também é ser, deixar de ser assim" e "por desflorar-me é que não tenho fim". A lição da rosa manifesta-se também como um desejo de totalidade e eternidade, ambos garantidas pela aceitação dessa condição negativa.

Não é à toa que a ideia de um mar absoluto será central para o título da obra em questão, assumindo uma importância definitiva em relação aos outros poemas, que gravitam em torno dessa tonalidade impositiva. Viagem e Vaga Música são títulos que desejam indicar uma delicadíssima ausência, seja pelo deslocamento da viagem, seja pela imprecisão da canção. Já Mar absoluto e outros poemas marca uma presença que se impõe, reunindo dois elementos que têm em si algo do incomensurável: o mar, que na perspectiva do humano é gigantesco, e o absoluto, que, do ponto de vista das ideias, configura algo da ordem do que não pode ser medido. A síntese dessa experiência totalizante será uma forma de vazio, já que o absoluto será entendido pela poeta como uma incorporação do múltiplo, que nivelado, esvazia as

\footnotetext{
${ }^{19}$ Cecília Meireles. “4 Motivo da Rosa”. Idem. (Mar absoluto e outros poemas). p. 384.

${ }^{20}$ Eliane Zagury propõe que a primeira parte de Mar absoluto e outros poemas é dividia em razoável simetria pelos 5 motivos da rosa. Cecília Meireles: notícia biográfica, estudo crítico, antologia, discografia, partituras. Petrópolis, Vozes, 1973. p. 38.
} 
particularidades para incluí-las no todo. O que veremos de forma mais detalhada durante a análise dos poemas.

$\mathrm{O}$ encontro com o absoluto, de alguma maneira, motivará uma inflexão na lírica ceciliana. Como sabemos, a poesia de Cecília prefere os lugares próprios da tradição lírica, essa intimidade pura não oferece muito espaço para que o mundo exterior afete os estados de ânimo da poeta. Mesmo as coisas do mundo, na poesia ceciliana, existem na condição de símbolos (o barco, a flor, o mar, a estrela, a areia etc.). Em razão disso, podemos dizer que o movimento mais comum da poesia de Cecília Meireles, pelo menos até Vaga Música, é o de fechamento em si mesma, em seus símbolos e mitos. Contudo, uma leitura cuidadosa de Retrato Natural (1949), quarto livro da obra madura da poeta, mostra que o mundo exterior passa a assumir um lugar significativo, por mais que não supere a falta fundante da poesia:

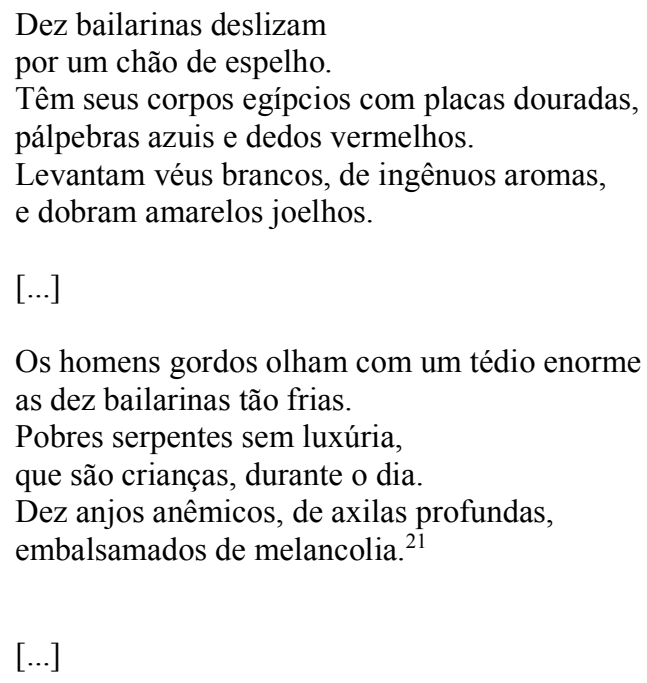

É considerável o contraste entre a materialidade de um poema como "Balada das dez bailarinas do cassino" e o " $4^{\circ}$ motivo da rosa" ou "Canção". Aqui, a inteligência da poeta recolhe do mundo exterior o motivo para sua reflexão sobre a falta, na tristeza das bailarinas e na anestesia dos "homens gordos". O modo ausente e quase dolorido das bailarinas faz a poeta mudar os rumos mais comuns de sua inteligência, para refletir sobre a condição de vida das mulheres que trabalham expondo seus corpos e da sociedade que as fruem com tédio. Nesse poema, a falta ceciliana vai representar uma dor social do gênero feminino e de uma sociedade apática que não o percebe, o que certamente configura uma abertura da poesia de Cecília Meireles para o cotidiano exterior da vida.

${ }^{21}$ Cecília Meireles. "Balada das dez bailarinas do cassino". Idem. (Retrato Natural). p. 573. 
Como viemos dizendo, as mudanças de uma obra para outra são delicadas, mas muito significativas. A "Balada das dez bailarinas do cassino" não representa o todo de Retrato Natural, obra com dezenas de poemas mais intimistas; contudo, indica um novo caminho para a poesia. Algo na relação do eu-lírico com a falta, depois do encontro totalizante em Mar absoluto e outros poemas, parece ter ganhado novas possibilidades expressivas através de uma abertura para o exterior. Tal abertura oferecerá à poeta maior movimento entre as demandas do mundo interior e do exterior. Será deste caldo que nascerá uma obra como Os doze noturnos de Holanda (1952) ou Poemas italianos (1953-56), em que a paisagem dos países e os homens que ali vivem motivam reflexões que vão além da fluidez da vida humana. Ou mesmo como um Romanceiro da Inconfidência, em que a história do Brasil e as demandas históricas do presente da época se reúnem naquela narração épica e fantasmagórica da Inconfidência Mineira.

Retrato Natural traz no título algo dessa abertura, numa espécie de apelo ao concreto. Claro que a concretude é intermediada pela ideia da imagem (do retrato), o que já diminui essa materialidade, mas certamente marca a diferença em relação às três obras anteriores que apelavam exclusivamente para o pensamento abstrato. Tal inflexão, como acreditamos, é preparada em Mar absoluto e outros poemas, dado o aliviamento que a experiência do absoluto traz para o sujeito. Será a partir dessa elaboração, reformulando a anterior dor da vida (tão definitiva em Viagem) que o eu-lírico ampliará o espectro de interação com o mundo exterior.

Eliane Zagury percebe a relação entre essas duas obras, contudo limita a ligação às duas partes finais de Mar absoluto e outros poemas.

\footnotetext{
Assim sendo, Mar Absoluto - livro (1945) anexa duas partes que estão visivelmente fora de contexto: "Os dias felizes" (sem data de composição) e "Elegia" (1933-1937). Entretanto a sua colocação no final do volume, em separado, vem formar uma ponte que permite um entendimento melhor do que virá a significar Retrato Natural. Depois de tanta poesia marítima, afinal Cecília pousa em terra, e em terra ensolarada, claro e tépido fermento da vida. $^{22}$
}

A separação da terceira obra madura de Cecília em três partes ${ }^{23}$ aponta para alguma autonomia entre elas, mas dificilmente as dispõe "fora de contexto" em relação umas às outras. A principal unidade do livro se dá justamente pelo elo entre o poema de abertura e o último: tanto "Mar absoluto" quanto "Elegia" tem como tema central a morte e as possíveis elaborações do luto. Apesar da reflexão da poeta direcioná-los para rumos diferentes, esses dois poemas

22 Eliane Zagury. Cecília Meireles: notícia biográfica, estudo crítico, antologia, discografia, partituras. Petrópolis, Vozes, 1973. p. 45. (Grifos da autora)

${ }^{23}$ Mar absoluto e outros poemas é divido em três parte: a primeira encabeçada pelo poema "Mar absoluto", a segundo por "Os dias felizes" e a última por "Elegia". Essa divisão foi organizada pela própria autora. 
emolduram o livro através de um viés biografista, raro para a lírica de Cecília Meireles, sempre mais dada à discrição. Além disso, os poemas de "Os dias felizes" não abandonam os temas desenvolvidos na parte anterior, o próprio tema da guerra reaparece, só que encarado de uma perspectiva mais distanciada do que em "Guerra" ou "Lamento da noiva do soldado". Na primeira parte de Mar absoluto e outros poemas, a guerra é entendida a partir das dores particulares, retratando as mazelas do conflito para as vidas individuais. Na segunda parte, a guerra é percebida como algo distante ("Jornal longe") mas que circunda os adventos cotidianos, ainda que de forma despercebida, como em "Joguinhos na varanda".

\footnotetext{
Meu parceiro joga com as bolas encarnadas:

"Se eu não ganhar desta vez, não dormirei a noite inteira.

"O inimigo está avançando. Mas eu tenho um plano estratégico.

"Estou imobilizado? Parece que caí num bolsão.

"Que fazer? Andar para trás. Depois, darei um grande salto.

"Conquistei uma posição. Isso agora é uma cabeça de ponte..."

E a lua, que sobrevoa terras e mares incendiados,

assiste ao jogo inocente, num quadrado de papelão.

Ilumina as bolas vermelhas, verdes, amarelas e pretas

com a mesma luz que envolveu os feridos, longe, de bruços,

e os mortos solitários que o sol amanhecente encontra. ${ }^{24}$
}

O poema forja, através do jogo infantil, uma linguagem da guerra que vai tomando proporção pela luz do luar, envolvendo tanto as crianças quanto os "feridos, longe, de bruços". Longe e perto, Cecília vê o homem abalado, e a perspectiva das dores individuais só faz iluminar a proporção do sofrimento coletivo, o que está presente na primeira parte e na segunda parte de Mar absoluto e outros poemas. Dividi-las como partes que não se comunicam é um erro, já que ambas retratam o ponto de vista da poeta em relação a um dos eventos mais traumáticos da história moderna.

Desse modo, a resposta da poeta à Segunda Guerra Mundial tem uma dimensão muito particular, em que não entram as polêmicas ideológicas, as táticas militares, nem a visão religiosa totalizante. Trata-se, antes, da "guerra miúda" ou da "guerra em surdina" [...]. A resposta de Cecília Meireles à guerra é, por excelência, civil, já que formulada a partir da experiência privada e doméstica, e, por esse fato, é também, mais do que qualquer outra entre nossos poetas, visceralmente pacifista. ${ }^{25}$

Fora isso, "Desenho", “Turista", "Miraclara Desposada", "Natureza morta”, "Estátua" (todos da primeira parte da obra) são também poemas de terra firme, ensolarados, "claros e

\footnotetext{
${ }^{24}$ Cecília Meireles. "Joguinho na varanda”. Idem. (Mar absoluto e outros poemas). P. 455.

${ }^{25}$ Murilo Marcondes de Moura. Mundo sitiado: a poesia brasileira e a Segunda Guerra Mundial. p. 248-249.
} 
tépidos fermentos da vida": "Isso era num lugar de sol e nuvens brancas, / onde as rolas, à tarde, soluçavam mui saudosas...”. Sabemos pela correspondência com Armando Côrtes-Rodrigues que Cecília havia se internado numa espécie de clínica de repouso ${ }^{26}$ onde compôs a série de poemas de "Os dias felizes", muito provavelmente em razão disso, o espaço nos poemas pareça mais delimitado e muito voltado para a contemplação e para a tranquilidade. Mas ainda assim, esse recuo antes de ser um defeito, prepara o leitor para "Elegia", por meio de um recuo do espírito para os ambientes da intimidade, como discutiremos adiante.

A unidade da obra ainda se garante pela repetição exaustiva de três temas: morte, destino e amor. Eles são o lastro fundamental de "Elegia" e "Mar absoluto" e como que encerram todos os demais poemas do livro nesse sentido. Cria-se, então, uma espécie de grande narrativa de um destino particular, da mulher que perdeu os pais, os irmãos e o marido, transfigurado em destino poético individual e coletivo. E a partir desse lugar faltante, a poeta encontra um caminho para diversas possibilidades de afeto. Acreditamos que Mar absoluto e outros poemas seja uma obra em que a poeta retoma sua história pessoal e lhe costura um sentido poético amplo, mais uma vez, dentro daquele desejo de totalidade. Talvez por ser um livro de madureza, (a poeta já contava com mais de quarenta anos nesse momento) haja tanto esforço de aparar as arestas de uma fortuna que lhe fiou uma vida repleta de perdas. Ao ressignificar o mau destino, em Mar absoluto e outros poemas, Cecília se assenta num sentimento de aceitação da falta e disso, acreditamos, frutifica uma abertura para o mundo. O desejo de encontro adquire, portanto, um patamar fundamental, apesar do outro ceciliano sempre se configurar como um inalcançável. Desenha-se o destino da navegante que, nessa obra, aceita o desafio de olhar para o centro de seu Mar Absoluto.

\section{Dos poemas escolhidos}

Os poemas selecionados para compor essa dissertação são: "Irrealidade"; "Mar absoluto" e "Elegia". Os dois últimos por emoldurarem o livro e por guardarem o motivo da falta como poder expressivo para o desejo de abertura de que viemos falando. Além de retomarem todo o tema autobiografico, em torno da morte e da ideia de um destino coletivo no

26 "Foram dias passados num clínica de repouso, aqui numa colina, uma casa onde se pode passar um tempo quando não é possível ir mais longe. Faz parte de uma cadeia de sanatórios americanos, e denominam-se 'Clínica White". É exclusivamente de repouso, com horários de refeições e de sono, alimentação vegetariana e científica, banhos de luz e massagens... Fica-se divinamente entregue ao ar, ao sol, à eletricidade, à água, sem raízes, sem relações sociais nem mesmo pontos de referência humanos. Uma dispersão." Lição do poema, cartas de Cecília Meireles a Armando Côrtes-Rodrigues. Org e notas, Celestino Sachiet. Ponta Delgada, Instituto Cultural Ponta Delgada, 1998.p. 93 
qual a poeta se vê inserida. Já com a escolha de "Irrealidade", tentamos descrever o lugar do qual essa poeta canta. Esse capítulo tem interesse de dialogar com temas fundamentais propostos pela fortuna crítica da autora assim como pensar a distância, que é uma constante dessa poesia, como mais uma forma da falta. Por conta de seu caráter mais amplo, iniciaremos pela análise de "Irrealidade", que muito funciona como uma apresentação do eu-lírico ceciliano em Mar absoluto e outros poemas. Tal análise será seguida da de "Mar absoluto" e por fim, "Elegia"; dois poemas que têm como sínteses movimentos muito distintos em relação a um tema muito similar. 
Não me parecia uma criatura inquestionavelmente real; por mais que aferisse os traços positivos de sua presença entre nós, marcado por gestos de cortesias e sociabilidade, restava-me a impressão de que ela não estava onde nós a víamos, estava sem estar, para criar uma ilusão fascinante, que nos compensasse de saber o incapturável de sua natureza. Distância, exílio e viagem transpareciam no sorriso benevolente que aceitava participar do jogo de boas maneiras da convivência, e era um sorriso de tamanha beleza, iluminado por um verde tão exemplar de olhos e uma voz de tão pura melodia, que mais confirmava, pela eficácia do sortilégio, a irrealidade do individuo. Por onde erraria a verdadeira Cecília, que, respondendo à indagação de um curioso, admitiu ser seu principal defeito "uma certa ausência do mundo". ${ }^{27}$

${ }^{27}$ Carlos Drummond, "Imagens para sempre” Correio da manhã, Rio de Janeiro, 11 de novembro de 1964, p.4. 


\section{Distância e afeto}

\subsection{Eu sou uma criatura de longe}

Ai! distâncias tão profundas...

E olho-me no espelho. ${ }^{28}$

Esse ensaio tem a dificuldade de querer retratar o incapturável que o sujeito ceciliano impõe ao mundo, o que traz diversos empecilhos à tarefa, uma vez que o retrato daquilo que não está é, geralmente, a constatação de sua falta. A poesia de Cecília Meireles é fundada nessa falta, por isso, quando um crítico como Alfredo Bosi considera que a "ausência do mundo" é "uma linha mestre que percorre toda a obra" ${ }^{29} \mathrm{da}$ autora, ele não quer nos dizer que a ausência é somente um grande tema da poesia, mas que ela é sua condição. Tarefa difícil e fundamental é entender porque uma poeta que tanto amou o mundo, e seu trabalho como educadora não deixa dúvidas quanto a isso, pôde dele afastar-se por tantas vezes.

Se é impossível dizer com certeza o que é essa distância do mundo, talvez devamos começar pelo que ela não é: a ausência de Cecília Meireles não é aquela do solitário ensimesmado ou daquele que rejeita a vida entre os homens. Notamos, durante a leitura de sua poesia, que essa distância do mundo, paradoxalmente, também é um enorme desejo de encontro. Tentaremos primeiramente apresentar aos leitores as formas da distância/ausência na lírica ceciliana, para que, depois de razoavelmente habituados ao universo dessa poesia, possamos analisar "Irrealidade", e a partir do poema, compreender o problema proposto.

Paulo Rónai, que fora um grande amigo de Cecília, tentou explicar como essa procura e essa ausência conciliavam-se nela de uma forma particular:

Privei da sua amizade, ao mesmo tempo ausente e presente. Essas duas maneiras aliavam-se nela, fundiam-se em paradoxal harmonia. É minha impressão que para a maioria dos amigos deveria ser o que era para mim: uma afeição em constante disponibilidade e entretanto algo longínqua. ${ }^{30}$

A paradoxal harmonização de que fala Rónai é a maneira do afeto daquele que se entende essencialmente solitário. De uma solidão que, como em Rilke, ao mesmo tempo, se abre para amplitude: "Se o próximo lhe parece longe, os seus longes alcançam as estrelas, são

\footnotetext{
${ }^{28}$ Cecília Meireles. Sonhos, in Poesia completa. Vol. II. Nova Fronteira, Rio de Janeiro, 2001. p. 1290.

${ }^{29}$ Alfredo Bosi. "Em torno da poesia de Cecília Meireles”, in Céu, Inferno. Editora 34, São Paulo, 2003. p. 123.

${ }^{30}$ Paulo Rónai, “Lembrança de Cecília Meireles”, in Pois é. José Olympio, Rio de Janeiro, 2014. p. 63-64.
} 
imensos. Alegre-se com esta imensidade para qual não pode carregar ninguém consigo" 31 ; e se concentra através do afeto: "Ame neles a vida sob uma forma estrangeira e tenha indulgência com os homens que, envelhecidos, temem a solidão [...]"32.

A solidão que amplia de Rilke é também uma forma de amar e de se aproximar. Sobretudo porque nessa solidão chega-se a algo que apesar de não poder ser imediatamente compartilhado, cria um projeto de retorno ao outro, mesmo que sem a presença física. No caso de Cecília, esse retorno é o da sacralização do humano. Isto é: de um amor profundo pelo passado e presente da humanidade.

\begin{abstract}
Tenho amigos em toda parte. Mas sou feito o Drummond que é tão amigo quase sem a presença física. Esse meu jeito esquivo é porque eu acho que cada ser humano é sagrado, compreende? Eu sou uma criatura de longe. Não sei se me querem mas eu quero bem a tanta gente! Sou amiga até dos mortos. Amiga de muita gente que nem conheci. Você não imagina quanta gente eu levo ao meu lado. E fico emocionada quando penso como uma criatura só recebe tanto de tantos lados, de tantas pessoas, de tantas gerações! ${ }^{33}$
\end{abstract}

Distância e afeto não são para Cecília, como podemos notar pelo trecho, modos contrastantes do ser, senão, participam de um mesmo jogo das relações humanas, assim como para Rilke. Essa aparente ambiguidade é tão marcante para a poesia de Cecília que o afeto não chega a ser barrado pelo tempo linear ou mesmo pelo desconhecido, e a poeta se considera amiga dos mortos e de gente que sequer conheceu. Esse idealismo do sentimento acaba por flexibilizar o tempo linear tão profundamente que a poeta chega afirmar:

\footnotetext{
Sem sombra de positivismo, posso, no entanto, confirmar por experiência a verdade de que "somos sempre e cada vez mais governados pelos mortos". Porque nesse mundo emocional que o tempo acumula todos os dias nem o mais breve suspiro se perde, se ele foi dedicado ao aperfeiçoamento da vida. ${ }^{34}$
}

Essa forma de conceber o tempo é ao mesmo tempo agregadora e desagregadora. Por um lado, ela propõe uma temporalidade sem rupturas ou avanços, uma espécie de receptáculo que acumula a experiência "emocional" dos homens. Mas por outro, dificulta o trato com o cotidiano mais imediato, afinal, a vivência do aqui-agora se torna menos apreensível para aquele que aspira um tempo maleável e sem barreiras fixas, no qual a experiência humana possa transitar sem transtornos. A relação com o tempo é orientada, como acreditamos, por esse afeto

\footnotetext{
${ }^{31}$ Rainer Maria Rilke, Cartas a um jovem poeta. Trad. Paulo Rónai. 24a ed. Editora Globo, São Paulo, 1996. p. 41-42.

${ }^{32}$ Idem. Ibidem. p. 42.

${ }^{33}$ Entrevista feita por Pedro Bloch e publicada na revista "Manchete", Ed. no 630, em 16\05\1964. Disponível em: http://www.jornalopcao.com.br/posts/opcao-cultural/a-ultima-entrevista-de-cecilia-meireles

${ }^{34}$ Cecília Meireles. "Como escrevi o Romanceiro da Inconfidência”. In Romanceiro da Inconfidência. Global, São Paulo, 2012. p. 248.
} 
que não se limita à materialidade da experiência cotidiana, imprimindo nos leitores um efeito de imprecisão e distância, já que não lhes garante uma "clara definição dos elementos temporais ou espaciais, que lhes sejam imediatamente familiares ${ }^{35}$ ". Nos entraves dessa experiência com o tempo do cotidiano, o sujeito poético se submete a um profundo estado de exílio que pouco pode ser superado, já que ele se instaura enquanto forma de estar no tempo e no espaço: “Aqui não me entendem bem, sempre me acharam estranha, quase intrusa. E aí como me achariam? O mesmo. Eu sou criatura de exílio. De todos os exílios. " 36

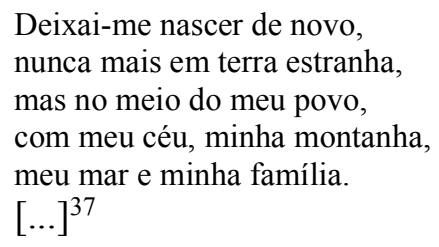

A questão de Cecília Meireles em relação ao exílio não é material, numa espécie de oposição entre o Brasil e outra terra, mas exige uma leitura metafísica, de uma condição espiritual. Por isso na carta a Armando Côrtes-Rodrigues, a poeta reconhece que mesmo nos Açores (a terra de sua família) ela seria uma "criatura de exílio". Porque sua falta é de um irrecuperável da origem, que pouco tem a ver com este ou aquele país.

Se o tempo pode ser vivido em sua grandeza, sem quebras, a poeta decide que o seu lugar não está no aqui-agora ("terra estranha"), mas num outro tempo que reúne aquilo que lhe traz pertencimento e concentra seu afeto ("meu mar", "minha família", "meu céu”). Como a identidade está deslocada para um abstrato longe, o exílio torna-se uma condição intransponível e, assim, se fazem necessárias as sucessivas viagens, assunto tão caro à poética ceciliana. De forma mais ampla, esse exílio também se aproxima daquele de Baudelaire, em "O albatroz", condição do poeta moderno que ambiciona as alturas mas é posto a caminhar, torto e desengonçado, ao lados dos homens. De qualquer modo, na poesia de Cecília, esse exílio é como uma força motriz, muitas vezes sentido com pesar e desengano e outras reformulando de maneira menos dolorida a experiência da ausência e da falta.

\footnotetext{
${ }^{35}$ Alcides Villaça. “Sobre Cecília em Portugal”. In GOUVÊA, Leila. Cecília em Portugal. São Paulo: Iluminuras, 2001.p. 13

${ }^{36}$ Lição do poema, cartas de Cecília Meireles a Armando Côrtes-Rodrigues. Org e notas, Celestino Sachiet. Ponta Delgada, Instituto Cultural Ponta Delgada, 1998. p. 72.

${ }^{37}$ Cecília Meireles. "Desejo de Regresso". Obra poética. (Mar absoluto e outrospoemas). José Aguilar, 1958. p. 319.
} 
É claro que o exílio que tratamos aqui diz respeito a uma atitude espiritual e poética, ligada à vida íntima, que nunca significou alheamento do mundo ou descaso pelas demandas do presente. Mesmo se dizendo "criatura de longe”, Cecília não rejeitou o mundo e viajou como poucos (Portugal, Estados Unidos, México, Uruguai, Argentina, Índia, sua amada ilha nos Açores, Porto Rico, Israel, Grécia e Itália, sem contar com as viagens nacionais). Sempre mantendo uma atitude curiosa e aberta em relação aos novos lugares ${ }^{38}$, para os quais não abria só o coração, mas sua poesia. Além disso, atuou, nos anos 30, para a reforma do ensino, principalmente através de publicações regulares de crônicas, sempre muito críticas, sobre educação e cultura ${ }^{39}$. Mas o caso é que em sua obra poética, qualquer tipo de engajamento social teve pouco espaço ${ }^{40}$ e o contato com o mundo foi quase sempre entremeado por uma espécie de tela que resguarda sua condição de estrangeira primordial, a qual, mesmo repercutindo certo ônus para o trato cotidiano, favorece na poesia de Cecília Meireles um olhar incomum e imaginoso, que possibilita suas viagens naquele acúmulo do tempo e das experiências humanas.

$\mathrm{Na}$ condição daquele que sente todo o "breve suspiro" da história, a poeta recorre à imaginação para poder alcançar seu ideal de encontro, mais uma vez costurando distância e afeto, o que é tão bem ilustrado em "Reinvenção":

A vida só é possível reinventada.

Anda o sol pelas campinas e passeia a mão dourada pelas águas, pelas folhas... Ah! tudo bolhas que vem de fundas piscinas de ilusionismo... - mais nada.

Mas a vida, a vida, a vida, a vida só é possível reinventada.

Vem a lua, vem, retira as algemas dos meus braços. Projeto-me por espaços

\footnotetext{
${ }^{38}$ Muitos poemas e obras completas nasceram dessas viagens, talvez os melhores exemplos sejam: Os doze noturnos de Holanda (1952), Poemas italianos (1953-56) e Poemas escritos na Índia (1953).

${ }^{39} \mathrm{O}$ que foi largamente estudado por Valéria Lamego em A Farpa na Lira: Cecília Meireles na revolução de 30. Rio de Janeiro: Record, 1996.

${ }^{40}$ São pontuais os momentos em que a poeta permite que as demandas diretamente histórias penetrem em sua poesia. Podemos citar: "Elegia a Gandhi", em que a poeta suspende seu estado de "pastora de nuvens" e trata dos jornais e do assassinato do líder pacifista; os poemas de Guerra; e o próprio Romanceiro da Inconfidência. Mesmo nesses exemplos, com exceção de "Elegia a Gandhi", a poeta desenvolve os temas a partir de um movimento dialético entre distância e proximidade. $\mathrm{O}$ qual, tentamos explicar nesse ensaio.
} 
cheios da tua Figura.

Tudo mentira! Mentira

da lua, na noite escura.

Não te encontro, não te alcanço...

Só - no tempo equilibrada,

desprendo-me do balanço

que além do tempo me leva.

Só - na treva,

fico: recebida e dada.

Porque a vida, a vida, a vida, a vida só é possível

reinventada. ${ }^{41}$

O mote da canção é o famoso verso: " vida só é possível reinventada”, repetido em oposição a tudo que se mostra concreto ("campinas", "águas", "folhas", "lua" etc.). Esse procedimento estilístico aponta, de alguma forma, para a incompletude dessa vida material, na qual o idealismo ceciliano não encontra correspondente (“tua Figura"). E já que tudo é "ilusionismo", a poeta retoma a solidão, através do jogo entre os homônimos "só" advérbio e "só" adjetivo, e desprende-se do real para reafirmar a vida através da imaginação. Aliás, reinvenção-invenção, imaginação, fantasia, fazem parte de um grande campo semântico em sua obra, sempre se opondo ou expandindo o real.

E por força de seus exercícios de reinvenção da vida, fora poucas exceções, tudo a que Cecília se dispõe pensar, acaba transfigurando o real, uma vez que sua atitude imaginativa assume uma postura radical frente ao que entendemos comumente por realidade. Por conta disso, o mundo em seus poemas é geralmente transfigurado. Todo aquele gosto pelo banal, pela cidade e pelo humor que nutriu a experiência estética do Modernismo, não conseguia expressividade nessa poesia que desloca a realidade a todo instante. Leila Gouvêa percebe que quando o prosaico ganha forma na poesia de Cecília é como se nele houvesse uma "antinomia, por vezes uma dialética, entre os olhos corporais e os "olhos do entendimento"” 42.

- Para este mundo vão meus pensamentos, tão estrangeiros, tão desapegados, como se esta varanda fosse a Lua. ${ }^{43}$

O verso final de "Distância" indica justamente a antinomia de que fala Leila Gouvêa, os olhos corporais reconhecem a varanda, os olhos do entendimento enxergam a Lua. A

\footnotetext{
${ }^{41}$ Cecília Meireles. "Reinvenção”. Obra poética. José Aguilar, 1958. (Vaga Musica).p. 249.

${ }^{42}$ Leila Gouveia. Pensamento e "Lirismo Puro" na poesia de Cecília Meireles. São Paulo: EDUSP, 2008. p.70.

${ }^{43}$ Cecília Meireles. "Distância”. Ibidem. (Mar absoluto e outros poemas.) p. 320.
} 
comparação mantém resguardadas tanto a Lua quanto a varanda, mas cria um enorme "entre" no qual se elaboram, novamente, distância e afeto. Talvez encorada nesse mesmo "entre", Cecília tenha escrito num bilhete a sua amiga Lucia Machado de Almeida ${ }^{44}$ :

"Você acha que as pessoas inteligentes morrem? escreveu-me ela certa vez. Acho que não. Pelo menos não morrem tanto quanto as outras. Isso é uma teoria que ando inventando. Porque os inteligentes estão atentos à própria morte e os outros desatentos à própria vida. Agora não lhe posso explicar melhor, mas havemos de conversar sobre isso". ${ }^{45}$

A atenção à morte e, consequentemente, à vida coloca o homem num estado suspenção, criando essa espécie de lugar entre a varanda e a lua, onde não há ações e o pensamento transita sem coincidir com a finitude humana. Essa posição diante do concreto, que é a constatação de um exílio primordial e espiritual, vai alcançar também um dos temas mais importantes de sua poesia madura: a busca pela própria identidade ${ }^{46}$.

Todo o movimento que vai da ausência ao afeto atravessará os poemas de representação do eu. Neles, há o desejo do encontro consigo, conquanto haja também um descompasso entre os olhos do corpo e os olhos do entendimento, a dinâmica faz com que o sujeito que se vê (no retrato ou no espelho) não consiga apreender o visto, pois é quase sempre atravessado por um lapso (do tempo, dos sentidos, do intelecto, do espírito). Esse lapso, que é outra forma da ausência, faz com que o sujeito perceba um descompasso entre uma mobilidade externa e uma imobilidade interna e se veja múltiplo-fragmentado, como que numa imagem atualizada incessantemente.

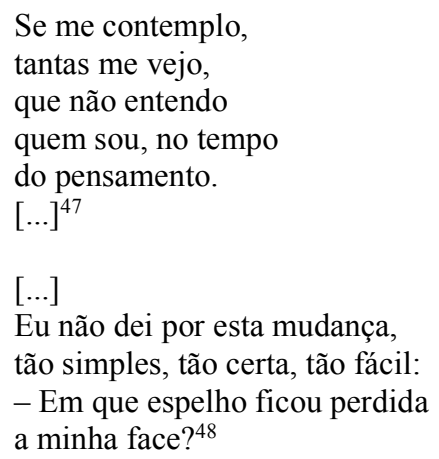

\footnotetext{
${ }^{44}$ A quem Cecília Meireles dedica dois poemas: "Para Lúcia Machado de Almeida" e "Dias da rosa" in Poesia completa v. II, Rio de Janeiro, Nova Fronteira, 2001. Pags. 1617 a 1678.

${ }^{45}$ In "Esse instante emprestado". Publicado no "Suplemento Literário" do Diário de São Paulo em 20/02/1965, nessa mesma edição há outros textos em homenagem a Cecília Meireles.

${ }^{46}$ O que Nádia Batella Gotlib discute em "Cecília Meireles: construção do autorretrato”, in Ensaios sobre Cecília. São Paulo: Humanitas-FAPESP, 2007. P. 97-109.

${ }^{47}$ Cecília Meireles. “Autorretrato”, Obra poética. (Mar absoluto e outros poemas) 1958. p. 301.

${ }^{48}$ Cecília Meireles. "Retrato". Ibidem. (Viagem) p. 10.
} 
Entre o desenho do meu rosto

e o seu reflexo,

meu sonho agoniza, perplexo. ${ }^{49}$

[...]

Fui mirar-me num espelho e era meia-noite em ponto.

Caiu-me o cristal das mãos

como as lembranças no sono.

Partiu-se meu rosto em chispas

como as estrelas num poço.

Partiu-se meu rosto em cismas

- que era meia-noite em ponto. ${ }^{50}$

A ação do inventar-imaginar, que poderia nutrir essa ausência, não é capaz de alcançar o vazio, ou ainda o exílio espiritual, que atinge tão drasticamente o eu que tenta ver a si mesmo.

Há nesse ponto uma grande diferença entre esses poemas voltados para o sujeito e àqueles que se voltam para o mundo das plantas, dos animais e das miudezas. A natureza oferece uma estabilidade e inteireza que possibilita o retrato, só sendo quebrada pela presença humana. $\mathrm{O}$ que será visto em "Elegia", quando a natureza atualiza imagens do fluir da vida e a poeta as rejeita, buscando a avó.

No poema "O jardim"51, toda a natureza está plena e cada elemento que compõe o quadro tem seu lugar preciso. Contudo, a chegada do homem deixa o que ali vivia e palpitava, tolhido.

$[\ldots]$

Quando um vulto humano se arrisca,

fogem pássaros e borboletas;

e a flor que se abre, e a folha morta, esperam, igualmente transidas, que nas areias do caminho se perca o vestígio de sua passagem.

A vida humana perde-se nas areias do tempo e, por isso, perturba a natureza de eternos ciclos. Enquanto as flores se sucedem umas às outras, a cada primavera, os homens, individuais, têm seu fim definitivo na morte. O mundo dos homens, em razão disso, não afeta somente a ordem natural da vida que se renova, mas implica também em toda a sorte de desacordos na convivência com seus iguais, dada sua individualidade experimentada sempre em contraste.

Numa primeira impressão, o mundo visto por Cecília Meireles é exemplo de incompreensão, transtorno e desacerto. O trato humano é de difícil realização: o que se diz não é o que se

\footnotetext{
${ }^{49}$ Cecília Meireles. "Epigrama do espelho infiel”. Ibidem. (Vaga Música)p. 157.

${ }^{50}$ Cecília Meireles. "Fui mirar-me”. Ibidem. (Retrato Natural) .p. 320.

${ }^{51}$ Cecília Meireles. “O jardim”. Ibidem. (Mar absoluto e outros poemas).p.442-443.
} 
entende; a avaliação das coisas e de nosso comportamento se faz por parâmetros não coincidentes; divergem as pessoas no grau de sensibilização aos matrizes afetivos. ${ }^{52}$

A poeta vivencia esse "desacerto", como bem formulou Darcy Damasceno, com algum espanto, gerado principalmente pela diferença profunda entre sua percepção e a do outro, o que é também outra faceta da distância, agora, nas teias das relações humanas. Nesse choque, Cecília não afirma um verdadeiro da percepção, pelo contrário, faz conviver formas até antagônicas sem uma valoração imediata. Na crônica "Não creias nos teus olhos", a poeta elabora, a partir da observação de um casal num restaurante, a história de uma índia brasileira. A moça loira, usando um vestido de "seda azul" e comendo de garfo e faca, vai, aos pouquinhos (e com certa manobra da história do Brasil), se tornando a índia enamorada de um bandeirante que almoça ao seu lado. A crônica poderia terminar nesse exercício da fantasia, afirmando-o como superior a objetividade dos fatos (o vestido, os hábitos de alimentação, a cor do cabelo); mas a chegada de um amigo dizendo: "Eu já venho bater um papinho com vocês: primeiro vou ali cumprimentar aquele casal italiano" ${ }^{33}$, retoma o título da crônica e nos deixa sem saber em quais olhos devemos crer. E a força da crônica, assim como da comparação entre a "varanda" e a "Lua" está justamente nessa suspensão, que atinge a sensibilidade do homem moderno, habituado a ideias de objetividade e ciência.

Em "Irrealidade", a poeta parece se propor a nos contar sua experiência de ausência diante dos olhos do outro. Por mais que esse também seja um retrato ceciliano, a presença do outro mobiliza na poeta um considerável esforço de aproximação, sempre na tentativa de um encontro verdadeiro. Movendo-se da distância ao afeto e do afeto à distância, Cecília constrói um retrato ilustrativo dos problemas com os quais se defronta e as respostas consideradas possíveis.
Como num sonho
aqui me vedes:
água escorrendo
por estas redes
de noite e dia.
A minha fala ${ }^{54}$
parece mesmo
vir do meu lábio
e anda na sala

\footnotetext{
${ }^{52}$ Nota editorial de Darcy Damasceno. In Cecília Meireles. O que se diz o que se entende. Nova Fronteira, São Paulo, 1980, p. 11.

${ }^{53}$ Cecília Meireles. O que se diz o que se entende. Nova Fronteira, São Paulo, 1980, p. 92.

${ }^{54} \mathrm{Na}$ Antologia poética, organizada pela autora e publicada em 1963, pela Editora do Autor, essa estrofe está dividida em duas, a segunda iniciada pelo verso "A minha fala".
} 


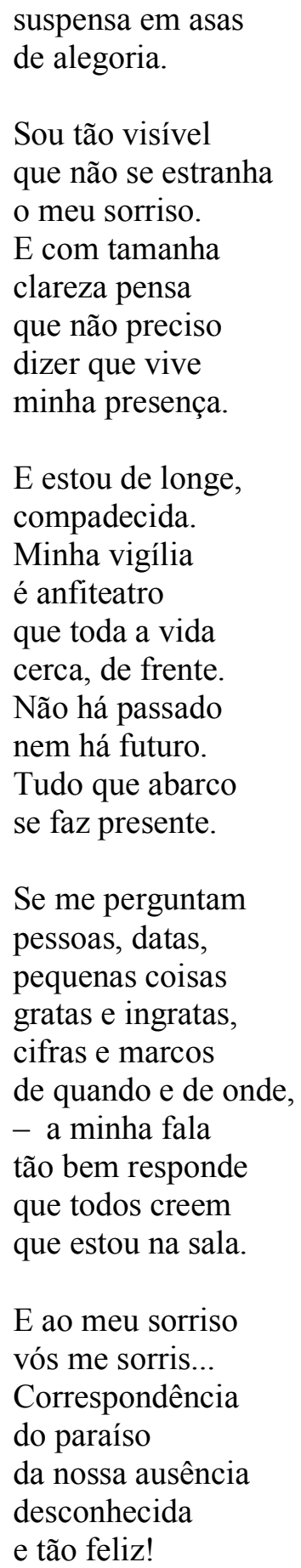

O poema é conciso e elegante, composto por quatro sílabas poéticas. A disposição das rimas ao final dos versos não é regular mas é constante, dando ao poema um interessante ritmo, bastante musical. Com exceção da última estrofe, todas as demais se iniciam com versos brancos, ou seja, que não terão um eco nas próximas rimas, esse procedimento é muito instigante pois a regularidade razoável das rimas faz com que todo o primeiro verso crie uma 
expectativa que não vigora. O leitor procura essas correspondências sonoras no poema da mesma forma que Cecília busca sentido na interação entre os homens. Como se sabe, a acentuação interna no verso de quatro sílabas obedece dois modelos: $\sim \sim^{\prime} \sim \sim^{\prime}$ ou ' $\sim \sim \sim \sim^{\prime}$, a poeta alterna ambas as formas, aparentemente com a finalidade de afastar o máximo possível as sílabas fortes umas das outras, o que dá expressividade a uma atitude suave que, apesar do descompasso na interação humana, se mantém em todo o poema.

Embora não pertença ao plano do prosaico, "Irrealidade" possui um importante referencial objetivo: o encontro entre homens que conversam amenidades ("cifras", "datas", “marcos”). Esse referencial irá coexistir, em plano paralelo, com a vida íntima da poeta que não se mantém atada às pequenezas do dia-a-dia e inicia um longo questionamento sobre si mesma. Cecília inicia o poema com uma comparação que aproxima elementos divergentes e cria polos de contato entre o real e o sonho: "Como num sonho/ aqui me vedes". A comparação logo no primeiro verso expressa a distância que a poeta sente em relação ao outro que a percebe "como num sonho". Talvez a leitura desses dois versos deva ser amparada no título do poema e também na fala do amigo Paulo Rónai e revele a percepção sabida que Cecília tinha de seu afastamento.

Essa primeira estrofe se divide em dois momentos, o da visão e o da fala. A visão representará o que o outro vê e a fala, o próprio eu-lírico. Provavelmente, a cena retratada no poema se refere ao momento em que a poeta fala e seu interlocutor além de ouvi-la, a observa. A natureza da cena direciona o olhar do leitor para a construção do retrato da poeta, tanto pelo olhar do outro e quanto por sua própria voz. Os dois sentidos apontam para um descompasso que, numa primeira leitura, parece impossibilitar o contato; nessa medida, a visão fracassaria por incapacidade de conter a plenitude do visto e a fala por possuir um significado cifrado alegoricamente.

\footnotetext{
Como num sonho aqui me vedes: água escorrendo por estas redes de noite e dia.
}

O poema não tem a intenção de retratar o visto pela perspectiva do interlocutor, cujo olhar funciona como uma espécie de espelho em que a poeta se vê representada. Como o uso dos dois pontos tem uma função explicativa, o leitor espera que os versos seguintes tragam a descrição daquilo que o interlocutor vê, contudo, o outro não consegue ver nada de denso durante sua interação com a poeta, e ao modo do pescador fracassado, nos seus olhos se vê as redes vazias constatando o insucesso. Assim como o ocorrera nos retratos poéticos cecilianos, 
o olhar do outro também não é capaz de conter a imagem refletida. Nessa estrofe, a imagem da água escorrendo pela rede funcionará como representação daquilo que a poeta vê refletido no olhar do outro, como é comum à primeira parte de Mar absoluto e outros poemas, a metáfora é retirada do universo náutico. O eco entre às "redes" e a visão ("vedes") deseja criar um paralelo de equivalência, a semelhança repousa na ideia do vazio ou da atividade frustrada. Por isso a imagem da água que escorre é poderosa para compreendermos o que o outro vê em "Irrealidade": quando o interlocutor vê a poeta, ele só é capaz de constatar o que não está ali, ou melhor, só percebe a ausência, intensificada pelo uso do gerúndio ("escorrendo") que prolonga o tempo da relação entre quem vê e quem é visto, "de noite e dia", num exercício de esvaziamento.

De uma forma complexa, portanto, a poeta se percebe vista na medida em que não é vista. Seu retrato feito pelos olhos do outro descreve um desencontro que desassossega o cotidiano, porque o que era esperado (ser vista pelo outro) não ocorre, e acaba por lhe imprimir fraturas de vazio, de incomunicabilidade e de profunda solidão.

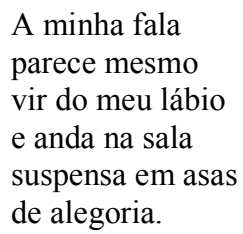

Já a fala da poeta se apresenta como um móbile que caminha suspenso no ambiente, mas não são cordas que o mantêm no ar, são "asas de alegoria". Sobre sua fala, a poeta conseguirá imagens mais descritivas, que digam as suas especificidades. A ideia fundamental que constrói o conceito de "alegoria" (cerne constitutivo da especificidade da fala no poema) pressupõe uma espécie de revestimento sobre o discurso, seja em prosa ou em verso. Esse véu dividiria a compreensão em dois ou mais momentos: um imediato, nascido pelo primeiro contato com o texto ou com a pintura, e, um segundo, que procuraria um significado oculto, latente, dito de forma não expressa mas intencional. Isso porque no universo alegórico a relação entre a coisa representada e o conceito a qual se refere não é óbvia e também não possui liberdade simbólica.

A alegoria, como a entende Walter Benjamin, é ambígua e estável, em oposição ao símbolo, autossuficiente e nascido de uma experiência temporal do instante. Como a alegoria depende de elementos externos a si mesma para ser compreendida, ela manterá uma relação estreitada com a natureza, com a história ou com o mito e, por isso, estará sempre apontando para uma totalidade que lhe falta. $\mathrm{O}$ autor também chama atenção para o caráter escritural da 
alegoria, uma vez que nas mãos do alegorista a coisa representada "transforma-se em algo diverso, através dela ele fala de algo diverso e ela torna-se para ele a chave que lhe dá acesso a um saber oculto que ele venera na coisa como seu emblema" "55. Em consequência disso, Bosi irá considerar que a alegoria "pesquisa a imanência do eu no outro" 56 , forçando "o leitor (ou o espectador) a perceber-se como aleatório e vulnerável, lançado em um mundo que lhe é estranho" $" 57$.

O leitor de "Irrealidade" sente-se vulnerável já na primeira estrofe do poema, pois a poeta vai construindo um sentido difuso, talvez ao modo Barroco, em que o paradoxo e uma delicada ironia vão, a todo o momento, dissimulando o conteúdo retratado. Como o dito e o visto estão deslocados de seus lugares habituais da comunicação corriqueira, é exigido do leitor atentar para a ambiguidade da palavra poética e entender o que a poeta deixa disfarçado. A rima entre a "fala" e a "sala" faz pensar que a natureza daquilo que é dito pertence ao nível do banal, da conversa desimportante, mas não só isso, afinal essa mesma fala está embutida de teor alegórico, o que sem dúvida a afasta do território das coisas banais. Como se sabe, a palavra "asa" pode também ser entendida, em sentido figurado, de forma semelhante ao adjetivo "ligeiro", o que traria à fala um sentido fugaz e leve. Nessa leitura, poderíamos entender que sua ascensão ("suspensa") funciona como uma forma de evaporação do sentido, primeiro pela suspensão e depois por sua ligeireza, o que é muito próprio dos assuntos tacanhos e corriqueiros que nascem e morrem ao gosto de modas e necessidades do cotidiano.

No entanto, essa suposta leveza é confrontada por sua condição alegórica, pois, como vimos, a alegoria depende de um núcleo estável que garanta sua compreensão. Como nos mantemos no nível alegórico, as coisas não representam aquilo que são imediatamente, por isso a fala parece vir do lábio da poeta todavia está suspensa no ambiente ("anda na sala"), assinalando não só uma densidade desconsiderada como também alguma autonomia, em relação à falante.

Nas construções, "parece mesmo" e "suspensa em asas de alegoria", "esconde-se a expressão de um pensamento importante e perigoso, no que respeita a situação, atrás de uma expressão aparentemente inofensiva." ${ }^{58}$. Parece-nos que o perigo que a construção irônica dissimula, em "Irrealidade", é a ideia de que há um sentido estável em toda a fugacidade,

\footnotetext{
${ }^{55}$ Walter Benjamin. Origem do drama trágico alemão. Trad. João Barrento, Editora Autêntica, 2011, p. 196.

${ }^{56}$ Alfredo Bosi, “A máquina do mundo entre o símbolo e a alegoria”, in Céu, inferno. São Paulo: Duas Cidades, 2003. p.119

${ }^{57}$ Idem ibidem.

${ }^{58}$ Heinrich Lausberg. Elementos de retórica. Trad. R. M. Rosado Fernandes. Fundação Calouste Gulbekian, Lisboa, 2011. p.246.
} 
afetado invariavelmente pela perda de significação no trato cotidiano. A conjunção "e" no verso "e anda na sala" materializa esse jogo de dissimulações. Numa primeira leitura poderíamos entendê-la como uma conjunção coordenativa, como é o mais comum, mas nesses versos ela acaba tendo uma força adversativa fundamental, já que a "fala" parece vir do lábio da poeta mas na verdade está suspensa em "asas de alegoria".

O retrato construído nessa primeira estrofe aponta para um jogo de ausências, seja pela imagem trazida pelo olhar do outro, seja pela fala alegórica. Entretanto essa mesma fala que se esconde também revela uma espécie de âncora que irá iluminar, assim como acreditamos, a natureza da ausência/distância e até mesmo flexibilizá-la, afinal na alegoria, as coisas "trazem a marca do terreno, demasiado terreno. Nunca se transfiguram a partir de dentro, e daí vem sua irradiação na ribalta da apoteose." 59

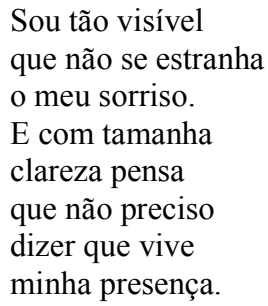

Se na primeira estrofe fomos apresentados ao problema do descompasso entre a percepção e a experiência do sujeito, na segunda, será desenvolvida a tensão entre as noções comuns de presença e ausência. É a partir dos questionamentos sobre a presença daquilo que se vê, que a poeta prepara o leitor para seu específico longe, que se justificará nas estrofes seguintes, como resposta a uma realidade que não oferece elementos suficientes para apaziguar a inteligência do sujeito.

Por conta disso, o advérbio "tão" ("Sou tão visível”) é ainda calcado naquela ênfase irônica de que falamos acima, visto que essa pequena partícula se contrapõe ao primeiro verso da estrofe seguinte: “E estou de longe [...]”, construindo a ideia de que apesar de visível o sujeito está ausente. Nessa estrofe é possível propor uma divisão interna, marcada pelo verso "E com tamanha", que interrompe uma sequência de sucessivas sibilantes ("visível”, "estranha", "sorriso", "clareza", "pensa", "preciso", "presença) com a força das oclusivas (/c/ e /t/), essa cisão faz ressaltar certo incômodo da poeta frente à pretensão de "realidade" garantida ao que é visível. Reiterando esse desacordo, há ainda a quebra de expectativa sonora entre o primeiro

${ }^{59}$ Walter Benjamin. Origem do drama trágico alemão. Trad. João Barrento, Editora Autêntica, 2011, p. 191. 
e o sétimo verso. Diferentemente dos demais versos que compõem essa estrofe ("estranha"/ "tamanha"; "sorriso"/ "preciso"; "pensa"/ "presença"), esses dois não possuem sua exata correspondência sonora, de forma que o visível não se encaixa exatamente com o vivo ("visível" / "vive"), o que resulta num alargamento da ideia de vida, que não necessariamente se mostra visível.

As duas primeiras estrofes constatam um deslocamento e indicam um caminho para fora do trivial, algo já presente na fala alegórica e nos questionamentos sobre presença e ausência. O movimento do restante das estrofes será, consequentemente, o de afastamento em relação ao cotidiano e paradoxalmente de aproximação em relação às lacunas deixadas nas estrofes anteriores.

O jogo entre ausência e presença é muito produtivo para o imaginário da poesia ceciliana, criando belas imagens; acreditamos que um dos mais contundentes exemplos seja o Palácio do Vento (Hawa Mahal) indiano, o objeto do poema "Jaipur", de Poemas Escritos na Índia (1953). O vazio e a solidão sugeridos pelos ventos que dão nome ao palácio são reafirmados na estrutura arquitetônica do Hawa Mahal, que fora planejada para que as mulheres do harém pudessem observar a rua sem serem vistas através das muitas janelas cobertas de rendilhas. Para as mulheres que viveram no Palácio do Vento, tal estrutura implicava numa espécie de presença-ausente, já que os de fora não podiam percebê-las, mas elas percebiam a todos.

\section{$[\ldots]$}

Adeus, astrólogo.

Muitos deuses sobre o Palácio do Vento.

(Onde eu devia morar!)

Sobre o Palácio do Vento meus adeuses: pombos esvoaçantes.

Meus adeuses: rouxinóis cantores.

Meus adeuses: nuvens desenroladas.

Meus adeuses: luas, sóis, estrelas, cometas mirando-te.

Mirando-te e partindo,

Jaipur, Jaipur. ${ }^{60}$

A poesia ceciliana efetivamente habita esse lugar afastado e ao mesmo tempo presente, o que torna muito dificultosa a tarefa crítica de entender seu lugar de fala enquanto poeta. Em "Irrealidade", o longe ("E estou de longe") que se inscreve no poema também depende dessa presença-ausente do Palácio do Vento, pois mesmo afastada e solitária, a poeta está rodeada

\footnotetext{
${ }^{60}$ Cecília Meireles. Poesia Completa vol.II. Org. Antonio Carlos Secchin. In Poemas escritos na Índia. Nova Fronteira, Rio de Janeiro, 2001, p. 1028.
} 
por uma enorme plateia, onde não se sentam homens individuais mas "toda a vida". A experiência do tempo, no poema, está cercada de frente por um estado de vigília que nivela passado, presente e futuro num novo tipo de presente, o qual será desenvolvido na terceira estrofe através da imagem do anfiteatro. A escolha do verbo "abarcar" ("Tudo que abarco") retoma, acusticamente, o universo náutico (a- $\underline{\text { barco }})$ anunciado pelas "redes" no início do poema e faz pensar nas metáforas náuticas descritas por Curtius ${ }^{61}$, uma vez que tal abarcamento é a transposição da vida cotidiana, com seu tempo linear, para a poesia lírica e seu eterno presente. Parece-nos, portanto, que a "solução" da distância vem para o eu-lírico através da transfiguração da vida (necessariamente reinventada) na poesia.

A poeta se encontra em vigília no centro desse palco, sua posição é de cercamento e, ao mesmo, de frontalidade. Há aqui, além de uma sobreposição de tempos, um encontro de espaços: "que toda a vida/ cerca, de frente". Tanto a ideia de "anfiteatro" quanto a do verbo "cercar" pressupõe uma espacialidade circular e se choca, portanto, com a locução "de frente". O sentimento que organiza esse contraste é o de represamento de sentidos e direções que apontam para uma poesia que se compromete, em sua solidão de exilada, a vigiar pela vida humana.

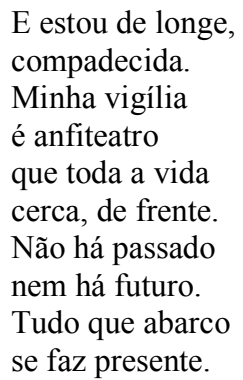

A distância, e, consequentemente, o exílio vivenciados pela poeta são aqui de ordem temporal ("tudo que abarco/ se faz presente"), o que a afasta do resto dos homens é uma sensibilidade afiada do tempo, que impede a percepção sensorial de fixar-se - mesmo que a razão, a cada passo, reconheça seu movimento aniquilador para as relações mais imediatas do trato cotidiano. Nessa terceira estrofe, a regularidade das rimas finais se dilui, mantendo-se

61 Ernst Robert Curtius. Literatura Europeia e Idade Média Latina. Trad. Teodoro Cabral (Colaboração de Paulo Rónai). Editora da Universidade de São Paulo, São Paulo, 2013. p. 175-176: Os poetas romanos costumam comparar a composição de uma obra com uma viagem marítima. Compor é "Fazer-se a vela, velejar" (vela dare: Virgílio, Georgicas, II, 117). Na conclusão das obras, as velas são colhidas (vela trahere, idem, IV, 117). O poeta épico viaja num grande navio sobre o largo mar; o lírico numa pequena canoa pelo rio. [...] O poeta torna-se marinheiro; e seu espírito ou sua obra, o barco. 
somente em "presente" / "frente", numa espécie de inauguração de caminho e direção, que ganha tônus na redução do tempo linear (passado, presente, futuro) em um só tempo ${ }^{62}$. Tal formulação supera a condição humana, não no que tange à imortalidade da pessoa, mas ao alcance do pertencimento, àquilo que um homem pode abraçar como seu; o abarcamento das expressões do tempo num presente contínuo acaba por fazer com que todos os tempos e homens passados e futuros se encontrem, naquele acúmulo da experiência histórica, de que ela mesma fala. Essa ideia de pertencimento total poderia se contrapor ao estado de exilada do qual viemos falando, contudo a criação desse estado temporal é vivida como fratura, cada atualização do tempo em novo presente é um despedaçamento em prol dessa vigilância contínua, o que prossegue apartando a poeta do tempo linear e, portanto, dos homens cotidianos e da rotina.

Os versos "Minha vigília/ é anfiteatro", sugerem ideia de um sujeito sempre atento à vida que o cerca e também lhe cobra atenção. Como a palavra "vigília" carrega consigo a ideia de um esforço árduo, da necessidade ou da fé, é razoável que consideremos que a poeta se disponibiliza diante dessa missão, aceitando-a por amor. O estado de "compadecida" é resultado desse afeto, que parece se consolidar através de uma ideia de sofrimento, padecimento.

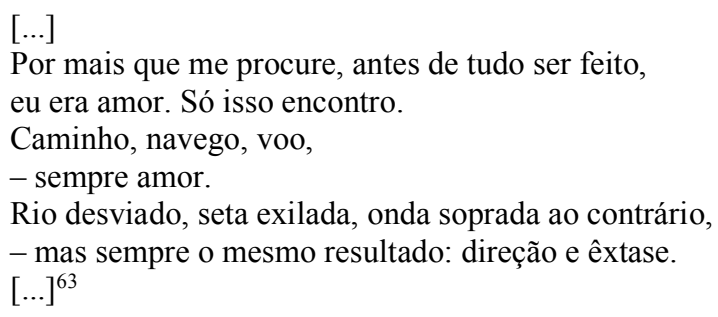

A distância que vai se construindo no poema corrobora para uma visão ampla do Humano e possibilita que o afeto se estenda a "toda a vida". Só do longe, a poeta consegue apreender uma espécie de unidade da condição do homem, os versos: "E estou de longe,/ compadecida" dão a ver a relação dependente entre a distância e a empatia, visto que somente afastada da rotina a poeta pode enxergar ou escutar os lamentos dos séculos, dos objetos, dos animais e de tudo o que já não tem voz, no presente da vida cotidiana.

Que gosto de longe - mas de um outro longe - há em cada objeto, em cada animal, em cada criatura! E que paciência de obedecer a um secreto compromisso! Tão sérias as coisas! Tão

${ }^{62}$ Como foi sugerido pelo Prof. Dr. Augusto Massi, durante a defesa dessa dissertação, a questão do estar cercado não se limita ao conteúdo, ganhando expressividade também na forma do poema, uma vez que será na estrofe central (terceira de cinco) do poema que a poeta se vê cercada.

${ }^{63}$ Cecília Meireles. "Contemplação”, in Obras completas. (Mar absoluto e outros poemas) Rio de Janeiro, José Aguilar, 1958. p. 297-299. 
sérios, os animais e as plantas. Envoltos num sonho espesso. Andando, comendo, crescendo - mas sempre dormindo. Viajando como todos nós para a morte [...]. ${ }^{64}$

As coisas, os animais e as plantas acessam com facilidade o longe ceciliano, dormem porque sua existência é suave e inserida no mundo. Andam, comem e crescem num universo coberto de sentido, todavia não um sentido que se encerra em si mesmo, mas se afirma no movimento e no reconhecimento do transitório ("Viajando como todos nós para a morte") e a lucidez sobre a condição viageira da vida só prospera através da distância. Hannah Arendt, pensando a alienação do mundo na modernidade, formula: "nada que possa ser medido permanecerá imenso ${ }^{65}$ ". Ou seja, tudo que a ciência ajudou a mensurar corroborou para um apequenamento do mundo que não é mais amado como a casa dos homens, mas é só uma estrela que circula o Sol. De alguma maneira, a distância que Cecília estabelece com as coisas do mundo é uma maneira radical de não quantificar medidas, sejam elas quais forem. Em razão disso, sua poesia preserva o imenso da Terra e dos homens.

A síntese entre o afastamento e a empatia é complexa e certamente retoma o início desse ensaio e talvez represente o maior enigma da poesia de Cecília Meireles: "decifrar o paradoxo dos ecos do mundo na própria ausência 66". Em "Irrealidade", tais ecos (a conversa trivial) parecem se contrapor à vivência no longe, tendo como único vínculo aquele acúmulo da experiência histórica humana que invariavelmente compartilhamos, conscientes ou não disso. Isso porque a poeta encara a história e também a poesia como conteúdo de sofrimento e, portanto, necessariamente humanas.

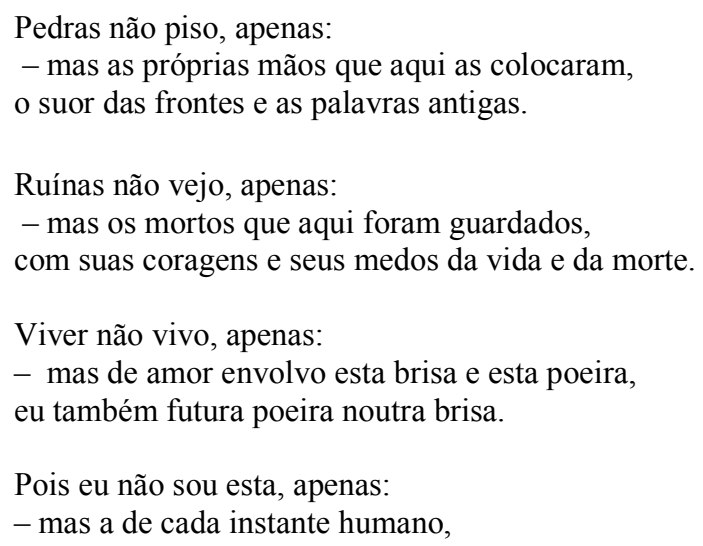

${ }^{64}$ Cecília Meireles. Olhinhos de gato. São Paulo: Editora Moderna, 1981. p. 9

${ }^{65}$ Hannah Arendt. A condição humana. Trad. Roberto Raposo. $11^{\mathrm{a}}$ ed. Editora Forense Universitária, Rio de Janeiro, 2013. p. 312

${ }^{66}$ Davi Arrigucci Jr. "Prefácio". In Leila Gouvêa. Pensamento e lirismo puro na poesia de Cecília Meireles. Edusp, São Paulo, 2008. p. 13. 
em todos os tempos que passaram. E até quando? ${ }^{67}$

Em "Via Apia", vemos que não importam apenas as ruínas, além e afrente delas, os homens com seus medos e coragens; o mundo da história e da poesia é aquele da experiência e sensibilidade humana, das vivências de dores e afetos, que se manifestam como substâncias próprias que, mesmo separadas de nós pelos séculos, nos atam a todos. Ser "a de cada instante humano, \em todos os tempos que passam" talvez ajude a elucidar essa ausência que é afeto para Cecília Meireles, pois pisar, ver e viver não são tarefas comuns, todavia estão ligadas à toda a vida que pisou, viu e viveu.

Num ensaio chamado "O encontro dos tempos", Alfredo Bosi comenta um trecho do diário de Giacomo Leopardi, em que o poeta, em 1823, discutia as dificuldades da poesia naquela século, chegando a afirmar: "Tudo pode ser contemporâneo deste século, menos a poesia"68. O crítico explica que a poderosa afirmação do poeta é nascida sob o signo da cultura burguesa, do homem atomizado, e, portanto, inábil para a poesia.

\begin{abstract}
Nessa cultura, o homem é átomo voltado para si, cortado da comunidade; e, átomo, concebe os outros homens e as coisas como outras tantas mônadas. Há pouco lugar para as formas de socialidade primária quando tudo é medido pelo status, pelos dinheiro, pelo caráter abstrato das instituições; e quase nenhum lugar para a relação afetiva direta com a Natureza e o semelhante. Egoísmo e abstração geram modos de sentir, agir e falar muito distantes das condições em que se produz a poesia: que é exercício próprio da empatia, das semelhanças e a proximidade. ${ }^{69}$
\end{abstract}

Dessa forma, além de se instaurar como lugar privilegiado para os assuntos da condição humana, o longe funciona também como uma alternativa para driblar a cultura burguesa que se solidifica por meio da aparência e se crê tão definitiva. O olhar de longe é uma forma de fratura existencial que traz àquele que lhe vivencia a possibilidade de olhar o mundo com um estranhamento lúcido e crítico. O reconhecimento do pó que já somos, nós e todas as coisas tocadas pela alma humana, provoca um deslocamento infinito e o presente simples, aquele da vida cotidiana, se torna uma impossibilidade dando lugar a um novo presente ("tudo que abarco/ se faz presente") que é um mover-se para lugar nenhum, ou nas palavras de Eduardo Lourenço, é um tempo em que "deslizamos, estranhamente parados, não para a Eternidade, mas na Eternidade." ${ }^{70}$.

\footnotetext{
${ }^{67}$ Cecília Meireles. "Via Apia”. Poesia Completa vol.II. Org. Antonio Carlos Secchin. In Poemas Italianos. Nova Fronteira, Rio de Janeiro, 2001, p. 1140.

${ }^{68}$ Alfredo Bosi. O ser e o tempo na poesia. São Paulo: Companhia das Letras, 2010.p. 131

${ }^{69}$ Idem. Ibidem. p. 131.

${ }^{70}$ Eduardo Lourenço, “Tempo e poesia”, in Tempo e poesia. Lisboa: Gradiva, 2003. p. 33.
} 
A escolha pelo anfiteatro, que metaforiza a vigília da poeta ("Minha vigília/ é anfiteatro"), está ainda calcada naquele sentimento de represamento (ou até mesmo de destinação). A estrutura desse espaço é formada por uma arena ao centro rodeada por uma construção circular que se eleva através dos degraus, essa arquitetura possibilita à plateia uma visão ampla do evento e coloca aquele que está no centro do palco totalmente exposto. No longe, Cecília não está só ou ausente, mas ocupa um lugar central, o ponto de vista é extraterreno e agregador ("que toda a vida/ cerca, de frente"), daquele que sabe ou crê ou aposta na possibilidade de algo estável frente ao perecível (como a fala alegórica da poeta já anunciava).

Na penúltima estrofe, de forma um tanto inesperada, há a retomada da sala e da conversa trivial.

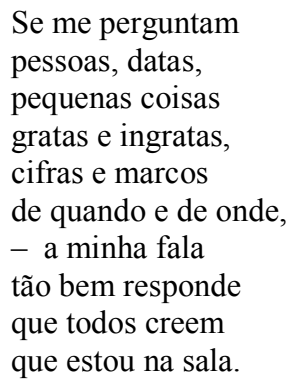

Em comparação à intensa vida no longe, há aqui um apequenamento do cotidiano, "pessoas", "datas", "cifras" e "marcos" são enumerados quase de forma despreocupada para salientar sua pequenez, afinal são formas de mensurar a vida e, portanto, a diminuem. Como podemos notar pelos versos: "que todos creem/ que estou na sala", a atitude do interlocutor é ambígua em "Irrealidade", ao mesmo tempo em que vê a poeta como num sonho, não duvida de sua presença na sala. As respostas sobre as coisas do mundo lhe garantem materialidade suficiente para a interação corriqueira e aparentemente, bastam ao interlocutor, o que a rima entre "fala" e "sala" também deixa ver. Esse desencontro vem sendo afirmado durante todo o poema assim como o movimento de distanciamento da poeta, a vida no longe é apresentada como uma necessidade e destinação, contudo a retomada da sala e da conversa ressalta um não abandono do cotidiano, que depois da viagem será ressignificado.

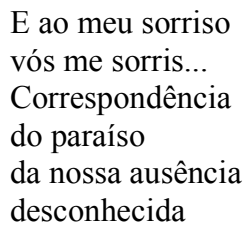


e tão feliz!

Ao finalizar o primeiro e o segundo verso com a imagem do sorriso, a poeta nos faz ver a possibilidade da troca. Uma troca que finalmente traz ao primeiro verso a procurada e exata correspondência sonora ("sorriso" / "paraíso") na constatação de uma ausência compartilhada (“da nossa ausência”), apesar de misteriosa (“desconhecida"). É importante reconhecermos que em "Irrealidade", o "paraíso" procurado está no outro, é através do outro que o eco sonoro se acerta e um sentido para o poema se afina, o que tão somente se torna possível após a experiência da vida no longe. A poeta não propõe uma superação dessa ausência ou o abandono do longe em troca das interações corriqueiras, o cruzamento dos sorrisos é ainda calcado na tensão entre distância e afeto, que para Cecília Meireles são indissociáveis.

Como não nos interessa resolver o enigma entre ausência e afeto, terminamos com as belas palavras de Rilke que ajudam a entender como o estar longe pode ser uma forma de amar mais completa justamente por aceitar a incompletude da vida humana:

\begin{abstract}
Mas a aprendizagem é sempre uma longa clausura. Assim, para quem ama, o amor, por muito tempo e pela vida afora, é solidão, isolamento cada vez mais intenso e profundo. O amor, antes de tudo não é o que se chama entregar-se, confundir-se, unir-se a outra pessoa. Que sentido teria, com efeito, união com algo não esclarecido, inacabado, dependente? O amor é uma ocasião sublime para o indivíduo amadurecer, tornar-se algo em si mesmo, tornar-se um mundo para si, por causa de um outro ser; é uma grande e ilimitada exigência que se lhe faz, uma escolha e um chamado para longe. ${ }^{71}$
\end{abstract}

\title{
1.2 O que se ganha no longe?
}

O sujeito poético em "Irrealidade" poderia sugerir algo da situação do melancólico. Apesar de não se mostrar como a já canônica representação alegórica da melancolia ${ }^{72}$, com a cabeça apoiada nas mãos e o olhar vago; sua postura mental "aponta a presença do corpo que pesa, do espírito que se ausenta ${ }^{73 "}$. Entretanto, o que para o melancólico é uma cisão pouco conciliável, em Cecília Meireles, as polaridades (corpo-espírito) são suavizadas, pois a vida no longe não está completamente descolada daquela da conversa cotidiana, de tal maneira que o sorriso final ilumina uma correspondência. $\mathrm{O}$ espírito que se ausenta encontra vivacidade na experiência do longe, reafirmando, portanto, uma nova ligação com o real. $\mathrm{Na}$ verdade, o

\footnotetext{
${ }^{71}$ Rainer Maria Rilke, Cartas a um jovem poeta. Trad. Paulo Rónai. 24a ed. Editora Globo, São Paulo, 1996. p. 56.

${ }^{72}$ Nos referimos à Melancolia I, de Albrecht Dürer, 1514.

${ }^{73}$ Jean Starobinski, Melancolia diante do espelho. Trad, Samuel Titan Jr. São Paulo, Editora 34, 2014. P.45-46
} 
encontro com o outro parece só achar caminho depois de tal experiência do longe, como tentamos mostrar durante a análise.

Tal suavização só ocorre porque Cecília Meireles promove um deslocamento do olhar e passa a ver a si mesma também através da perspectiva do longe. Nesse desdobrar-se, o eu experimenta uma alteridade de si e, assim, suaviza contrastes que poderiam mantê-lo no estado melancólico, pois: "O olhar do melancólico fixa o substancial e o perecível: sua própria imagem refletida. O olhar do espectador, por sua vez, deve elevar-se na direção oposta"74.

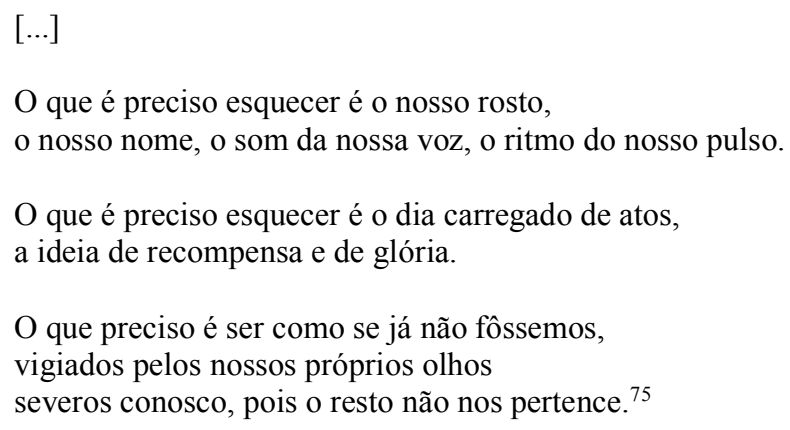

O sujeito ceciliano é espectador da marcha do mundo e constatando a fluência dos seres e das coisas, opta por um afastamento que é como uma depuração extrema, num longe onde não importam a identidade, o cotidiano, o gosto por determinada cultura ou qualquer elemento que se mostre efêmero na prova do tempo. Essa descrição poderia nos fazer pensar que "Irrealidade" se distancie daqueles poemas de representação do eu que comentamos no início desse ensaio. Mas isso seria um engano. Na verdade, o fenômeno é o mesmo: o ser é posto frente a sua condição transitória. Nos poemas de representação do eu, a poeta se assombra pela efemeridade que a afronta e pergunta pela identidade que lhe escapa, entretanto o espanto não é a única resposta ceciliana ao tempo, há também a aceitação que geralmente vem acompanhada por um sentimento de dever, compromisso, destino, missão. Em vista disso, a mágoa da morte só é superada pelo desapego e pela distância, que propiciam, de uma forma muito produtiva para a poesia, uma experiência fora do banal da rotina.

É possível que muitos considerem essa postura idealista ou ingênua, contudo, ela resgata um olhar humanista que, muitas vezes, parece faltar ao homem moderno. De toda a forma, já em 1929, em "O espírito victorioso", Cecília propunha uma educação que atentasse para o irrefreável movimento da vida, de tal forma, que oferecesse certa mobilidade ao espírito

\footnotetext{
${ }^{74}$ Idem. Ibidem. p. 47.

${ }^{75}$ Cecília Meireles. "É preciso não esquecer”, Poesia Completa vol.II. Org. Antonio Carlos Secchin. In Dispersos. Nova Fronteira, Rio de Janeiro, 2001, p. 1926.
} 
humano. Uma mobilidade que reconhece o enigma e, portanto, flui nele, sem qualquer pretensão de resolvê-lo definitivamente.

\begin{abstract}
Nós, os de hoje, podemos tentar uma eternidade assim: sem o egoísmo de nossa fixação. Que sabemos nós, de tudo quanto possamos ter aprendido, senão que a vida é uma perpétua instabilidade e que sua forma de definição suprema é a constância de um movimento de sempre renascentes ritmos? Do reconhecimento da marcha das aparências sobre a irrevelação invariável ficou, para os espíritos que a observaram, uma larga sede de rumos e fins. Mas a vida, bem se vê, é uma continuidade e não apenas uma direção. Ela está em si mesma, com as suas formações precárias, florindo como os sonhos sobre uma noite imperturbável. Mas é a mesma natureza dessa noite e desse sonho. Entre uma e os outros opera, unicamente, a magia transfiguradora do movimento. Nestes sucessivos cenários efêmeros que resultam de nossa própria efemeridade é preciso que não nos arroguemos nenhuma atitude irremovível, porque seria recusarmos a seguir a correnteza natural em que, sem explicações, aparecemos. Nosso desacordo com a natural sequência nos insularia num espontâneo exílio em que não participaríamos nem da aparência transitória nem da inviolável eternidade, porque é preciso sentirmos a deslocação dolorosa de uma para possuirmos em nós o gosto profundo e absoluto da outra. ${ }^{76}$
\end{abstract}

O exercício de se colocar sempre em direção de uma distância é forjar esse movimento - a "deslocação dolorosa" - que pode, ao fim, oferecer aos leitores o "gosto profundo e absoluto" da eternidade. Como já comentamos, esse afastar-se para um longe, sem com isso romper com a realidade, é um procedimento poético fundamental para a poesia ceciliana, e ele representa uma espécie de imaginação dinâmica que se move incessantemente. Bachelard entende a imaginação como "a faculdade de libertar-nos das primeiras imagens, de mudar as imagens" ${ }^{77}$, em Cecília Meireles a imaginação pretende libertar o sujeito de um cotidiano sem significado, mero “formigar" sem sentido. Em razão disso, o longe é, sobretudo, uma alternativa para a experiência resgatada da banalidade do cotidiano moderno.

Agamben, em "Infância e história: ensaio sobre a destruição da experiência"78, explica que o incômodo do homem moderno em relação ao cotidiano nasce justamente da "incapacidade de traduzir-se em experiência"79, já que os eventos do dia-a-dia não conseguem conformar nada que resulte em experiência. O filósofo considera que a "expropriação da experiência estava implícita no projeto fundamental da ciência moderna”, já que essa deseja um "método" (oposto exato do tatear incerto da experiência) como caminho para o conhecimento. De forma diferente da "ciência moderna", os antigos entendiam que a imaginação, "hoje

\footnotetext{
${ }^{76}$ Cecília Meireles, O espírito victorioso. Rio de Janeiro, Editora Anuário, 1929. Apud Yolanda Lôbo, Cecília Meireles. Pernambuco, Editora Massangana, 2010, p. 78-79.

${ }^{77}$ Gaston Bachelard. O ar e os sonos: ensaio sobre a imaginação do movimento. Trad. Antonio de Pádua Danesi. Editora Martins Fontes, São Paulo, 1990. p.1.

${ }^{78}$ Giorgio Agamben. Infância e História: destruição da experiência e a origem da história. Trad. Henrique Burico. Editora UFMG, Belo Horizonte, 2014.

${ }^{79}$ Idem. Ibidem. p. 22
} 
eliminada do conhecimento como sendo <<irreal $>>$, era [...] o médium por excelência do conhecimento" ${ }^{80}$, ocupando o lugar que "nossa cultura confere à experiência".

A imaginação, em "Irrealidade", cria a ponte entre o objetivo e o subjetivo, possibilitando à poeta a chance de sofrer uma experiência no longe, onde compadecida, ela assume uma espécie de sentimento da história humana, que reúne os tempos e a nós todos em nossa falta essencial. Ao transitar pela "magia transfiguradora" que aproxima a noite e o sonho, Cecília Meireles parece se aproximar da noção de experiência dos antigos, cuja finalidade era:

conduzir o homem à maturidade, ou seja, a uma antecipação da morte como ideia de uma totalidade consumada da experiência, ela era de fato algo de essencialmente finito, e logo, era algo que se podia ter e não somente fazer $^{81}$

O sujeito ceciliano se posiciona à contra mão daquilo que se esperaria da lírica moderna, que de acordo com Collot, não encara mais o sujeito "em termos de substância, de interioridade e de identidade, mas em sua relação constitutiva com um exterior que o altera". ${ }^{82}$ O movimento de Cecília Meireles parece-nos o oposto da preceituação do autor, pois somente através do recuo íntimo e da imaginação que o eu-lírico se vê capaz de interagir com o outro e com o mundo exterior. As mudanças do pronome pessoal na última estrofe ajudam a ilustrar esse movimento:

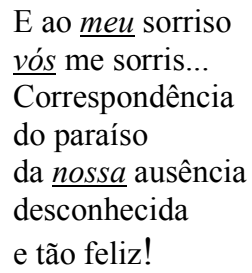

Depois do retorno do longe, a poeta parte em direção ao outro ("meu sorriso") que lhe corresponde ("vós me sorris") e juntos constroem o elo possível ("nossa ausência”), cuja força é derivada de todas as negatividades que atravessam a vida humana. A lírica de Cecília Meireles entende que nossas dificuldades de troca com o outro, o medo, a morte, a passagem dramática do tempo agregam aquilo que nos constitui de modo mais profundo: só na aceitação dessa eterna “deslocação dolorosa”, nos encontramos.

\footnotetext{
${ }^{80}$ Idem. Ibidem p. 33

${ }^{81}$ Idem. Ibidem p.32

${ }^{82}$ Michel Collot. O sujeito lírico fora de si. Trad. Zênia de Faria e Patrícia Sousa Silva Cesaro. Signótica, v. 25 , n. 1, p. 221-241, jan./jun. 2013. p. 224.
} 
Adormece o teu corpo com a música da vida.

Encanta-te.

Esquece-te.

Tem por volúpia a dispersão. Não queiras ser tu. Quere ser a alma infinita de tudo. Troca o teu curto sonho humano Pelo sonho imortal. O único.

Vence a miséria de ter medo. Troca-te pelo Desconhecido. Não vês, então, que ele é maior? Não vês que ele não tem fim? Não vês que ele é tu mesmo? Tu que andas esquecido de ti?

${ }^{83}$ MEIRELES, Cecília. "IV”, in Cânticos. Poesia completa, Vol. I. Nova Fronteira, 2001, p. 122-123. 


\section{A morte abstrata e o amor concreto}

"Mar absoluto" talvez seja um poema que quer tocar diretamente nos assuntos da trajetória humana sobre a terra, cuja força repouse na menina que perdeu pai, mãe e irmãos antes de entender o que era a perda. $\mathrm{O}$ eixo que conduz seus versos é guiado pelo desejo de reencontro com esses mortos para sempre perdidos e as possibilidades de elaborar essa falta fundante. É claro que esse motivo não limita o poema que se abre para tantos outros níveis de significação, mas é ele o núcleo estável que dá rumo à navegação. O poema inicia-se num movimento de recuo íntimo, bastante lírico, que se inspira na visão e na escuta do mar, entretanto, vai, aos poucos, se orientando para um apelo mais amplo e genérico, até por fim, chegar ao mar absoluto. É preciso atentar para um profundo controle íntimo da poeta que ao mesmo tempo inicia uma viagem poética sem perder o lastro do real, retomado mais ao fim do poema, quando ela mesma se percebe em frente à janela olhando o mesmo mar que lhe possibilitou uma superação de si mesma.

Escrito em verso livre, "Mar absoluto" não cede à coloquialidade e à fluência da prosa. O ritmo se mantém melódico, com recorrentes enjambements, reforçando o movimento constante dos versos. Há o predomínio de rimas toantes e aliterantes, e uma especial atenção devemos dar à repetição de sibilantes e vibrantes, que acabam por simular o som das ondas retração das águas através das sibilantes e o ruído da onda que arrebenta nas vibrantes: "Foi dessde sempre o mar./ E multidões passadas me empurravam// como a barco esquecido". A irregularidade métrica, recurso raro na poesia de Cecília que prefere os metros curtos e regulares, unida à recorrência de vibrantes e sibilantes faz com que o ritmo do poema seja guiado pelo marulho das ondas e pela urgência de um sujeito que se depara com o dever e a necessidade da navegação. A assimetria entre os versos também garante ao poema um contorno ondulado, marcado pelo ápice dos versos mais longos; ilustrando a imagem do próprio movimento do mar.

A atmosfera criada nesse poema é ao mesmo tempo onírica e epopeica, uma vez que vemos retratada uma navegação abstrata, na qual não há precisão sobre o percurso, os navegantes, o lugar de partida ou de chegada. Todos esses elementos de exatidão material perdem a importância em face do sentimento de destinação. Por ser um poema bastante múltiplo, apesar do tema orgânico, veremos um movimento constante de ressignificação da função da navegação, num exercício de buscar alternativas para a superação da morte. Como se trata de um poema longo, optamos por dividi-lo, uma vez que "O que denominamos um 
poema longo é, de fato, apenas a sucessão de alguns curtos, isto é, de breve efeitos poéticos." ${ }^{\text {" }}$. Chegamos ao total de seis partes, cada uma delas com certa unidade referente às imagens desenvolvidas.

Nossa leitura busca justificar a divisão a partir da variação de tempos e sujeitos verbais, além das mudanças narrativas do percurso e da atitude da poeta com relação a sua missão. Nomeamos as partes de "Mar absoluto" da seguinte maneira: A recordação; O motivo; Eu, eles: nós; Conhecendo o mar; Búzios da lembrança; O outro mar. Pensamos assim conseguir iluminar o itinerário da poeta que vai da recordação de um destino coletivo ao reconhecimento das particularidades da missão.

Para ilustrar a divisão, marcamos graficamente com barras duplas os versos finais de cada parte:

Foi desde sempre o mar.

E multidões passadas me empurravam

como a barco esquecido.

Agora recordo que falavam

da revolta dos ventos,

de linhos, de cordas, de ferros,

de sereias dadas à costa.

E o rosto de meus avós estava caído

pelos mares do Oriente, com seus corais e pérolas, e pelos mares do Norte, duros de gelo.//

Então, é comigo que falam, sou eu que devo ir.

Porque não há mais ninguém, não, não haverá mais ninguém, tão decidido a amar e a obedecer a seus mortos.

E tenho de procurar meus tios remotos afogados.

Tenho de levar-lhes redes de rezas, campos convertidos em velas, barcas sobrenaturais

com peixes mensageiros

e santos náuticos.

E fico tonta, acordada de repente nas praias tumultuosas.

E apressam-me, e não me deixam sequer mirar a rosa dos ventos.

${ }^{84}$ Edgar Allan Poe. "Filosofia da composição". Poemas e Ensaios. Trad. Oscar Mendes e Milton Amado. $3^{\mathrm{a} e d .}$ Editora Global, 1999, p. 103. 
"Para adiante! Pelo mar largo!

Livrando o corpo da lição frágil da areia!

Ao mar! - Disciplina humana para a empresa da vida!'//

Meu sangue entende-se com essas vozes poderosas.

A solidez da terra, monótona, parece-nos fraca ilusão.

Queremos a ilusão grande do mar, multiplicada em suas malhas de perigo.

Queremos a sua solidão robusta, uma solidão para todos os lados, uma ausência humana que se opõe ao mesquinho formigar do mundo, e faz o tempo inteiriço, livre das lutas de cada dia.

$\mathrm{O}$ alento heroico do mar tem seu polo secreto, que os homens sentem, seduzidos e medrosos. //

O mar é só mar, desprovido de apegos, matando-se e recuperando-se, correndo como touro azul por sua própria sombra, e arremetendo com bravura contra ninguém, e sendo depois a pura sombra de si mesmo, por si mesmo vencido. É o seu grande exercício.

Não precisa do destino fixo da terra, ele que, ao mesmo tempo, é o dançarino e a sua dança.

Tem um reino de metamorfose, para experiência: seu corpo é o seu próprio jogo, e sua eternidade lúdica não apenas gratuita: mas perfeita.

Baralha seus altos contrastes: cavalo épico, anêmona suave, entrega-se todo, despreza tudo, sustenta no seu prodigioso ritmo jardins, estrelas, caudas, antenas, olhos, mas é desfolhado, cego, nu, dono apenas de si, da sua terminante grandeza despojada.

Não se esquece que é água, ao desdobrar suas visões: água de todas as possibilidades, mas sem fraqueza nenhuma. //

E assim como água fala-me.

Atira-me búzios, como lembrança de sua voz, e estrelas eriçadas, como convite ao meu destino. 
Não me chama para que siga por cima dele, nem por dentro de si:

mas para que me converta nele mesmo. É o seu máximo dom.

Não me quer arrastar como meus tios outrora, nem lentamente conduzida, como meus avós, de serenos olhos certeiros.

Aceita-me apenas convertida em sua natureza:

plástica, fluida, disponível, igual a ele, em constante solilóquio, sem exigências de princípio e fim, desprendida de terra e céu. //

E eu, que viera cautelosa, por procurar gente passada, suspeito que me enganei, que há outras ordens, que não foram bem ouvidas; que uma outra boca falava: não somente a de antigos mortos, e o mar a que me mandam não é apenas este mar.

Não é apenas este mar que reboa nas minhas vidraças, mas outro, que se parece com ele como se parecem os vultos dos sonhos dormidos.

E entre água e estrela estudo a solidão.

E recordo minha herança de cordas e âncoras, e encontro tudo sobre-humano.

E este mar visível levanta para mim uma face espantosa.

E retrai-se, ao dizer-me o que preciso.

E é logo uma pequena concha fervilhante, nódoa líquida e instável, célula azul sumindo-se no reino de um outro mar: ah! do Mar Absoluto.

\title{
2.1 A recordação - o mar
}

\begin{abstract}
Assim como o caráter, o destino não pode ser inteiramente percebido em si mesmo, mas apenas em sinais, pois - mesmo que este ou aquele traço de caráter, este ou aquele encadeamento do destino possa se oferecer imediatamente à vista - o conjunto visado por esses conceitos não está disponível senão nos sinais, na medida em que ele se situa além do que oferece imediatamente à vista. ${ }^{85}$
\end{abstract}

${ }^{85}$ Walter Benjamin. "Destino e caráter" in Escritos sobre mito e linguagem. Trad. Susana Kampff Lages e Ernami Chaves. São Paulo, Editora 34, 2013, p. 90. 
O destino que se abre nas primeiras estrofes do poema é o da navegação, enquanto dever e necessidade. Como explica Benjamin, o destino e o caráter se configuram pelos sinais que nos oferecem, aos homens cabe o reconhecimento dos sinais e sua interpretação. A relação entre eles é sempre aproximada na história do pensamento e na literatura, já que o caráter e o destino são dependentes um do outro. Em "Mar absoluto", o destino vai se apresentar logo na primeira parte de nossa divisão, já o caráter da poeta vai se mostrando no decorrer do poema, a medida em que o sujeito lírico responde às demandas que vão se fazendo. No que se refere ao destino, ele se apresenta na descoberta do mar enquanto centralidade ou polo que reúne sentido à vida: "Foi desde sempre o mar". O tom desse primeiro verso é grave, nele ecoam as lembranças do passado e das vozes que o povoaram (“Agora recordo que falavam"), que retomadas funcionam como sinais a serem interpretados no seguir dos versos.

A navegação surge no horizonte da poeta como uma espécie de estalo que ressignifica o vivido até então, o advérbio na abertura do verso (“Agora”) aponta para essa atualização da experiência e sobre certo trabalho pessoal na elaboração das memórias e do passado. A recordação, no poema, não funciona como um simples lembrar-se de acontecimentos ou de coisas, mas como um estado especial do espírito, uma espécie de arrebatamento capaz de expandir a percepção do sujeito, tornando a memória uma forma de conhecimento interior e, posteriormente, supra-humano.

Vemos algo similar nas técnicas narrativas de Proust em Em busca do tempo perdido, romance no qual a memória involuntária, ou seja, aquela motivada por elemento externo, conduz a narração e a reflexão de seu narrador.

\begin{abstract}
Nas reflexões que introduzem o termo (memória involuntária), Proust fala da forma precária como se apresentou em sua lembrança, durante muitos anos, a cidade de Combray, onde, afinal, havia transcorrido uma parte de sua infância. Até aquela tarde, em que o sabor da madeleine (espécie de bolo pequeno) o houvesse transportado de volta aos velhos tempos sabor a que reportará, então, frequentemente -, Proust estaria limitado àquilo que lhe proporcionava a mémoire volontaire, memória voluntária; e as informações sobre o passado, por ela transmitidas, não guardam nenhum traço dele. ${ }^{86}$
\end{abstract}

A verdade possível sobre o passado, como considera Benjamin e também Proust, está fora da ação da inteligência voluntária. Isso porque o resgate do passado só é possível por meio daquilo que "não foi expresso e conscientemente vivenciado". ${ }^{87}$ Os símbolos e os sentidos

${ }^{86}$ Walter Benjamin. Obras escolhidas III: Um lírico no auge do capitalismo. Trad. José C. M. de Barbosa e Hemerson A. Batista. São Paulo: Brasiliense, 1994. p. 106.

${ }^{87}$ Idem. Ibidem. p. 108 . 
sensoriais acabam sendo ferramentas para essa experimentação, para o autor francês tudo se abre com o cheiro e sabor dos bolinhos, para Cecília, com a visão do mar. No caso da poeta, esse chamado impreciso vai construir uma recordação que se desvincula da memória cotidiana imediata e apela para imagens fabulosas (sereias, touros azuis etc.) -, criando uma memória afetiva interceptada pela fantasia e por construções simbólicas.

A escolha pelo uso dos verbos no pretérito imperfeito "empurravam" e "falavam", nas duas primeiras estrofes, respectivamente, retoma a dimensão narrativa da memória e a ideia de destinação. Como considera Rodrigues Lapa em Estilística da língua portuguesa, usar o imperfeito é se transportar "ao passado, pela fantasia e pelo sentimento" ${ }^{88}$. Esse tempo verbal pode representar com mais propriedade os afetos da poeta, por não ter a obrigação da objetividade comum ao pretérito perfeito, pois "usar o imperfeito é viver no passado, por um esforço de simpatia [...]". ${ }^{89}$ Consequentemente, o passado e o presente, por meio desse tempo verbal, se mostram aproximados dando-nos um sentimento de "misteriosa imprecisão" e ao mesmo tempo "impressão do interminável". O que nos faz pensar que o passado, em "Mar absoluto", não está morto ou acabado, mas ecoa ativamente no presente através da busca pelos ancestrais e no descobrimento de um destino particular. O uso do perfeito "foi", na abertura do poema, poderia desmentir nossa leitura, entretanto, seu caráter de passado acabado é posto por terra pela locução "desde sempre". Dessa maneira, o verso "Foi desde sempre o mar" se expressa com grande profundidade verbal, de modo que o caráter permansivo do imperfeito aparece acentuado nessa construção, remetendo-nos, de forma ainda mais precisa, a um tempo primitivo e de feição mítica.

Todo esse processo fora estimulado pelas "multidões passadas" ("E multidões passadas me empurravam"). A poeta era nas mãos desses misteriosos mortos tal como "barco esquecido", não atentando para onde as águas levavam-lhe. Essa multidão parece ter sido sempre presente, a poeta é que não atinava para os sinais que lhe eram enviados como chamamento. Apesar do termo "multidões passadas" pedir uma interpretação abstrata e um tanto genérica, faremos, a priori, um esforço interpretativo de compreendê-lo de forma mais palpável e precisa. Não queremos com isso subtrair a importante sombra que o envolve, mas, ao mesmo tempo, é impossível negar sua referência biográfica. $\mathrm{O}$ termo será retomado por expressões que garantem a construção de uma ideia de família, como "seus mortos", "meus tios", "meus avós". A composição desse grupo é variada, mas certamente entre tantos mortos há os antepassados de

${ }^{88}$ Rodrigues Lapa. Estilística da Língua Portuguesa. 2aed. (Revisada e Corrigida) Lisboa, Livraria Popular de Francisco Franco, [1959?]. p.220.

${ }^{89}$ Idem. Ibidem. p. 221. 
Cecília. Suas vozes são reconhecidas e uma dimensão familiar é atribuída ao grupo. Sua vinculação à viagem e à navegação é bastante interessante em "Mar absoluto", atualizando uma mitologia familiar em torno do mar. O mar, com todos os seus mistérios e aventuras possíveis, chega ao imaginário de Cecília através das histórias ouvidas, como vemos em sua correspondência e na narrativa de memórias Olhinhos de gato (1939-40). A infância de Cecília foi sustentada por fábulas, cantigas, histórias de viagens e, de forma indireta e lacunar, por relatos sobre seus pais e irmãos já mortos, tudo por conta de sua avó e da empregada da casa. A solidão da menina superprotegida e órfã era preenchida pelo afeto e pelas histórias que enchiam seus dias: "[...] minha infância foi como a de uma criança perdida na corte de Rei Arthur”; “[...] minha avó falava pouquíssimo, era extremamente mística também, e tinha um poder de fabulação poética notável [...]" ${ }^{90}$. Este ambiente repleto de fabulações foi constituindo e acentuando a atitude imaginativa da menina ("menina encantada", como ela própria considerou em sua correspondência com Armando Côrtes-Rodrigues) e, como acreditamos, preparando o solo fértil que integrará sua postura poética, sempre dada a fabulações.

Se há uma pessoa que possa, a qualquer momento, arrancar da sua infância uma recordação maravilhosa, essa pessoa sou eu. [...] Tudo quanto, naquele tempo, vi, toquei, senti, perdura em mim com uma intensidade poética inextinguível. ${ }^{91}$

Dentre tudo que foi ouvido e vivido, as histórias de navegação ocupam um importante lugar no imaginário poético de Cecília. Esse tema se torna poderoso por reunir demandas literárias e biográficas. Alcança a história familiar pela condição de migrante de seus avós maternos que vieram dos Açores para o Brasil, e, num âmbito mais amplo, a própria condição de navegante do povo lusitano. Além disso, a predisposição a partidas e viagens contempla ainda um desejo poético pela expansão dos limites físicos e temporais.

O mar, nesse poema, é representado ora como caminho para um vínculo preciso, ora como possibilidade de diluição total. Quando aponta para a família e para a herança de navegante, retoma uma sensação de pertencimento. Mas quando almeja um alargamento do tempo e da sensibilidade, volta-se para um sentimento de expansão total. Essa alternância é notada por meio das diferentes funções que a navegação vai ganhando durante o poema. Primeiro, ela dá forma ao anseio fundamental de traduzir para o presente os impactos de um passado familiar, e o mar, por consequência, acaba sendo o caminho para o encontro com as

${ }^{90}$ Lição do poema, cartas de Cecília Meireles a Armando Côrtes-Rodrigues, Ponta Delgada, Instituto Cultural Ponta Delgada, 1998, p. 13.

${ }^{91}$ Trechos de entrevistas reunidos na Obra poética, Editora Aguilar, 1958, p. LXXII. 
origens. Depois, torna-se um processo de viagem interna, e o mar, o meio para um alargamento da visão e percepção da poeta.

A simbologia em torno da figura do mar é vasta. De um modo geral, o mar é "Símbolo da dinâmica da vida. Tudo sai do mar e tudo retorna a ele: lugar dos nascimentos, das transformações e dos renascimentos" 92 . Dada sua relação com a vida humana, o mar revela tudo o que é incerto, impreciso e o que não conseguimos nomear. O mar é o entre que preenche as lacunas que não compreendemos, ocupando "o lugar entre o coração humano e o mundo ou entre Deus e nós". Em "Mar absoluto", o mar será o território no qual a poeta tecerá uma relação entre o vivido (em seu aspecto biográfico) e um destino poético universalista.

A correspondência entre a condição de marinheiro, imposta desde há muito tempo - por mais que reconhecida agora -, e sua herança familiar pode ser entendida pela segunda e terceira estrofes do poema. Nelas, compreendemos que as multidões foram responsáveis por narrar as histórias sobre o mar:

Agora recordo que falavam da revolta dos ventos, de linhos, de cordas, de ferros, de sereias dadas à costa.

A paisagem que se constrói em torno dessa lembrança é centralizada na imagem estática e fabulosa do rosto dos avós: "E o rosto de meus avós estava caído/ pelos mares do Oriente, com seus corais e pérolas,/ e pelos mares do Norte, duros de gelo.” É com encantamento e algum espanto que a poeta encontra esses rostos, cuja fisionomia assumiu as feições da natureza local, indicando as rotas de navegação. Os caminhos, "mares do Oriente" e "mares do Norte", não são gratuitos; apesar de Cecília ter grande apreço por viagens, grande parte de seu afeto está depositado em Portugal e na Índia. Como ela mesma considerou em entrevista: “[...] tudo me levava, ao mesmo tempo à Índia e a Portugal.” 93

Tamanha será a emoção que a contenção métrica da primeira estrofe $(6,10,6)$ vai se afrouxando a partir da recordação das narrativas ouvidas e ao chegar à figura dos avós, os versos se prolongam alcançando quinze sílabas poéticas. $\mathrm{O}$ que nos sugere que a lembrança afetiva toma a poeta e perturba a regularidade métrica anunciada na primeira estrofe.

\footnotetext{
92 Jean Chevalier e Alain Gheerbrant. Dicionário de símbolos. Mitos, sonhos, costumes, gestos, formas, figuras, cores, números. Rio de Janeiro, José Olympio, 1994.p. 592.

${ }^{93}$ Entrevista feita por Pedro Bloch e publicada na revista "Manchete", Ed. n 630, em 16\05\1964. Disponível em: http://www.jornalopcao.com.br/posts/opcao-cultural/a-ultima-entrevista-de-cecilia-meireles
} 
Destinada à navegação, a poeta segue sem saber se há uma Ítaca possível onde atracar. Como veremos, o poema não se resume à busca pela ancestralidade, mas a ideia da busca da origem funciona como impulso para Cecília alcançar as águas do Mar Absoluto.

\subsection{O motivo - a família}

O reconhecimento do destino, motivado pelas sugestões vindas do mar e de seu consequente passado, fez a poeta compreender sua condição de navegante. Pelas especificidades de seu caráter, a poeta aceita o chamado dos mortos e inicia sua navegação, cuja natureza não é marcada pelo afastamento gerado com a partida, mas pelo anseio comunicativo que busca retomar um contato perdido. Ao enxergar a partida como o caminho para o reencontro, o perfil do navegante vai se delineando: esse não é o homem que vislumbra um retorno. Na verdade, sua situação é a daquele que regressa para seu lugar originário, sempre guiado por um passado vivo e a procura de um transcendentalismo que possa reunir esse tempo ao presente.

Como se trata de uma navegação abstrata - realizada pela imaginação, pela memória e pela reflexão - os seus sinais serão sutis e podem passar despercebidos. A objetividade esperada de um poema narrativo sobre a navegação não se dá em "Mar absoluto". Em momento nenhum, vemos algo próximo da materialidade de uma Eneida, na qual é possível sentir o fresco e melancólico vento marítimo na partida de Cartago, quando Enéias, já nas águas, vê as fogueiras que o fazem pressagiar a morte de Dido. Na navegação ceciliana, despida de quase todos os elementos que lhe garantiriam uma referencialidade concreta, o percurso deve ser intuído pelo leitor.

Toda carga autobiográfica é aqui reiterada e como o poema é fruto de uma lembrança espiritual, essa segunda parte funciona como esclarecimento do que fora experimentado na primeira. Aqui, a natureza da viagem é precisada: a condição de urgência do navegante ("Então, é comigo que falam/ sou eu que devo ir”) e a razão da navegação (“e tenho de procurar meus tios remotos afogados"). A constatação da poeta atribui vitalidade ao passado, que de alguma maneira perdura nela e lhe impõe a navegação. Essa relação com o passado já estava implícita na escolha do imperfeito que agora será substituído pelo presente e pelo futuro (“falam”, "sou”, “devo", "tenho, "haverá"), ressaltando ainda mais o vigor do passado que a partir daqui se configura como presente ativo:

E fico tonta, 
acordada de repente nas praias tumultuosas.

E apressam-me, e não me deixam sequer mirar a rosa dos ventos.

O êxtase do reconhecimento do destino embaralha os sentidos da poeta e a transporta para as "praias tumultuosas" de onde sairá seu navio. O próprio adjetivo "tumultuoso" dá a essas praias um clima de agitação e alvoroço, sugerindo o porto no momento da embarcação.

$\mathrm{Na}$ estrofe de abertura d' $O$ motivo há a intenção de fornecer uma justificativa, que procura esclarecer a razão pela qual a poeta aceitou a missão sugerida pelas "multidões passadas": "Porque não há mais ninguém,\ não, não haverá mais ninguém,/ tão decidido a amar e a obedecer a seus mortos". Como se pode ver, a escolha não é gratuita ou totalmente deliberada pelo sujeito, ela se configura como obrigação dado seu caráter intransponível. Há uma regularidade interessante entre as palavras que terminam os versos que compõem a primeira estrofe dessa segunda parte.

Então, é comigo que falam, sou eu que devo ir.

Porque não há mais ninguém, não, não haverá mais ninguém, tão decidido a amar e a obedecer a seus mortos.

A repetição de "ninguém" não só pontua com firmeza a solidão do percurso, como anuncia uma crescente ausência que termina na morte. Esses três últimos versos insistem em imagens do vazio, mas que, como explica o poema, serão preenchidas pelo amor e pela obediência. E essa atitude afetuosa deve ser entendida enquanto vínculo com o passado, através de uma família de mortos que a chama e a faz decidir pelo amor e pela obediência. Esse amor forjado na escolha é bastante significativo no caso de Cecília Meireles, assim como o sentimento de responsabilidade pelos mortos. Ambos podem ser entendidos como derivações de condições biográficas. Toda espécie de amor que a poeta desenvolveu em relação ao seu núcleo familiar não foi construído com base na experiência do convívio, mas na imaginação, nos relatos ouvidos e nos vestígios de coisas espalhadas pela casa.

Certas peças tiravam com o maior cuidado: colchas de renda, camisolões de seda. Erguia-se aquilo nos braços como um corpo de criança. Murmurava-se: "Um enxoval tão bonito! Mal empregado! Uma pena! [...] Tudo era como nos sonhos. Traziam-se, levavam-se aquelas coisas. Mas parece que ninguém sabia por quê. ${ }^{94}$

\footnotetext{
${ }^{94}$ Cecília Meireles, Olhinhos de gato. São Paulo: Editora Moderna, 1981, p.6.
} 
Sendo o único membro da família restante, o encargo de resgatar esses mortos do esquecimento torna-se uma espécie de obrigação moral. Daí resulta também o comprometimento fiel e a intransferibilidade da missão. O tema da família perdida e do esforço para reconstruí-la é presente na lírica de Cecília, talvez o melhor exemplo disso seja "Memória", de Vaga Música ${ }^{95}$, em que a poeta tentará reconhecer o rosto de seus irmãos nos elementos da natureza. Apesar de ser trabalhado nos poemas, esse tema é elaborado de forma precisa em duas crônicas "Conversa com as crianças mortas" e "Mesa do passado". Nas duas, observaremos o esforço de reconstrução do não-conhecido.

\begin{abstract}
No entanto, éreis meus irmãos, e podíamos ter sido quatro crianças de mãos dadas brincando sob as laranjeiras. E eu fui só. Podíamos ter sido quatro adolescentes, deslizando, enlaçados, pela franja dos mares. E fui só eu. Podíamos ter sido dois homens e duas mulheres, pensativos, conversando sobre a vida. E eu fui só. Podíamos ter sido quatro velhinhos, um dia, relembrando-nos um a um. E sou eu que vos recordo. ${ }^{96}$
\end{abstract}

"Conversa com crianças mortas" é divida em três partes, cada uma dedicada a um dos irmãos - Carlos, Victor e Carmen. De tudo que é dito, nos chama mais a atenção o tratamento dado à irmã, com o sugestivo e simbólico nome de Carmen (que em latim significa poema, lírica, vaticínio), Cecília considera:

E por ti chorávamos mais. Porque eras a que servia, a que dava antes de ter. Por instinto de dar. Antes de seres e saberes, já te desdobravas, e inventava felicidade, sem teres pensado nisso. Eras poesia, Carmen. Porque a poesia é só dar, é só perder. Mas é difícil compreenderse isso. ${ }^{97}$

O exercício de reconstrução do passado, provavelmente amparado em relatos, fez com que a poeta visse em sua irmã morta um prenúncio da poesia. Poesia constituída pela atitude carinhosa de Carmen e que se fazia signo de um destino poético para Cecília. E como poesia "é só perder", a lírica ceciliana vai assumir grande familiaridade com a falta. Tamanha, que em "Caronte" 98 , a poeta se considerará "companheira" do barqueiro e não alma que ele simplesmente conduz.

Caronte, juntos agora remaremos: eu com a música, tu com os remos.

\footnotetext{
95 Poema analisado por Leila Gouvêa em "Inconsciente, mito, memória” in Pensamento e Lirismo Puro na poesia de Cecília Meireles. São Paulo, Edusp, 2008.

${ }^{96}$ Cecília Meireles, Crônica em Geral. Apresentação e planejamento editorial de Leodegário A. de Azevedo filho. Rio de Janeiro, Nova Fronteira, 1998, p. 209.

${ }^{97}$ Idem. Ibidem. p. 210.

${ }^{98}$ Cecília Meireles. Obra poética. (Mar absoluto e outros poemas) Editora Aguilar, 1958. p. 369-370.
} 
Meus pais, meus avós, meus irmãos, já também vieram, pelas tuas mãos.

Mas eu sempre fui a mais marinheira: trata-me como tua companheira.

Fala-me das coisas que estão por aqui, das águas, das névoas, dos peixes, de ti.

Que mundo tão suave! que barca tão calma! Meu corpo não existe: sou alma.

$[\ldots]$

Bachelard, em A água e os sonhos ${ }^{99}$, explica que o homem necessita de um guia que o ajude a fazer a travessia para os terrenos da morte, território tão desconhecido. A incerteza do caminho nos faz pagar os devidos tributos e esperar que Caronte (ou qualquer tipo de facilitador) faça conosco essa viagem derradeira. Cecília Meireles não entende Caronte como um facilitador, os terrenos do barqueiro também lhe pertencem. Como sabemos, não é privilégio de Cecília a capacidade de conhecer o mundo dos mortos, Orfeu, também por amor, apelou a Hades e Perséfone e dos infernos tentou trazer consigo Eurídice. Mas nunca Orfeu se sentiu tão à vontade nos infernos como o eu-lírico ao lado de Caronte.

Depois de muito ter chorado junto às brisas do céu, para não deixar de tentar até as sombras da morte, o vate do Ródope ousou descer ao Estíngio pela porta do Ténaro. Através dos povos insubstanciais e fantasmas de sepultados, chegou ao pé de Perséfone e do senhor que governa o desagradável reino das sombras. E dedilhando as cordas, assim cantou: $[\ldots]^{100}$

O reino das sombras para o poeta é "desagradável”, para Cecília é um "mundo tão suave". Orfeu desce ao mundo dos mortos com a missão de trazer Eurídice, a poeta de Viagem parece estar prazerosamente em trânsito, como que passeando. Pensando em "Mar absoluto", poderíamos dizer que a diferença entre a poeta e o barqueiro está no sentido de sua navegação. Enquanto Caronte conduz os mortos para seu destino final, Cecília conduz sua poesia para o encontro com eles, por mais que, efetivamente, toda aproximação seja signo de mais distância ou mudança de rota.

\footnotetext{
99 Principalmente no capítulo "Complexo de Caronte. Complexo de Ofélia”, São Paulo, Editora Martins Fontes, 1989, p.73-95.

${ }^{100}$ Ovídio. As Metamorfoses. Trad. Paulo Framhouse Alberto. Lisboa, Livros Cotovia, 2007. Livro X, v. 11-17.
} 
O desarranjo do encontro com os mortos amados em "Mar absoluto" parece nascido de duas razões. A navegação a que Cecília se propõe está cerceada por uma dificuldade prévia: seus mortos queridos são representados sem contorno definido ("multidões passadas", "tios remotos", "gente passada", "antigos mortos"), o que lhes dificulta o reconhecimento e também sugere uma ausência anterior. Tanto Enéias quanto Ulisses quando alcançam os infernos conseguem distinguir todas as sombras que lá habitam, além de reconhecer a essência do que foram e as marcas da morte em seus corpos. Os rostos dos mortos cecilianos acabam por se diluir num plano genérico, sua presença está marcada pelo signo da falta e sua natureza descaracterizada se tensiona com a aspiração do encontro.

Todos esses familiares, como a própria "multidão passada", são símbolos obscuros que anunciam um vazio inerente. Num ensaio particularmente bonito chamado "Símbolo y Silencio" 101 , Furio Jesi estuda os símbolos cujas imagens não evocam outras entidades, mas que repousam em seu próprio silêncio. No caso de Cecília, a distância temporal e a imprecisão na caracterização fazem com que a representação de todos esses familiares também acabe por ecoar somente silêncio. Esse efeito estilístico provavelmente não se resume à ação do inconsciente ou à falta que a poeta deve ter experimentado durante a vida, mas a uma representação cuidadosa da morte e das enormes dificuldades de reconstrução do passado.

O dever e a necessidade da navegação em "Mar absoluto" constroem uma espécie de mitologia pessoal da poeta, constituída a partir da crença de ser a única capaz de ouvir o chamado dos mortos (por afeto e destino), o que em "Irrealidade, como vimos, tomou a forma de um enorme sentimento da condição humana. No caso de "Mar absoluto", o sentimento parece ter motivação biográfica, seja pela proximidade travada com a morte desde a infância ${ }^{102}$, seja pela força definitiva da convivência com a avó e suas histórias. Em entrevista à revista "Manchete", a poeta conta que a avó fazia orações "por todos aqueles que sofrem"; continua: "A dignidade, a elevação espiritual de minha avó influíram muito na minha maneira de sentir os seres e a vida"103. Tal identificação e admiração foram tão significativas, que as histórias e preces ouvidas tornaram-se material para a poesia:

Sabe também porque me encantou? Por me fazer reviver umas orações que minha Avó tinha, já muito velhas, com uns barcos (creio que ela sempre dizia "fragatas") e parece que eram

${ }^{101}$ In Literatura y mito. Trad. Antonio Pigrau Rodrígues. Editora Barral, 1972, p. 17-34.

${ }^{102}$ A relação entre as experiências pessoais, principalmente com a orfandade, e a poesia de Cecília Meireles já foi tratada de forma cuidadosa por Leila Gouvêa em Pensamento e Lirismo Puro na poesia de Cecília Meireles (2008), no ensaio "Representação da ausência", p. 126-130. E também por Miguel Sanches Neto, Cecília Meireles e o tempo inteiriço, no prefácio à poesia completa da autora, publicado pela editora Nova Fronteira em 2001.

${ }^{103}$ Entrevista feita por Pedro Bloch e publicada na revista "Manchete", Ed. no 630, em 16\05\1964. Disponível em: http://www.jornalopcao.com.br/posts/opcao-cultural/a-ultima-entrevista-de-cecilia-meireles 
orações contra naufrágios [...] E minha Avó lia aquelas orações, que eu já sabia que eram Poesia, e me contava coisas de barcos virados n'água, e de gente sua, perdida. ${ }^{104}$

Esses afogados, parentes distantes que a avó não parece nominar ${ }^{105}$, tornaram-se "tios remotos" na boca da poeta ("E tenho de procurar meus tios remotos afogados"). Ao atribuir um vínculo parental preciso "tios", por mais que atenuado pelo adjetivo "remotos", a poeta aproxima de si todos os personagens das histórias, construindo uma espécie de grande família, mesmo que inventada e composta por mortos antigos.

E tenho de procurar meus tios remotos afogados.

Tenho de levar-lhes redes de rezas, campos convertidos em velas, barcas sobrenaturais com peixes mensageiros e santos náuticos.

Para que o contato com seus mortos ocorra, Cecília propõe uma forma de comunicação simbólica por meio da criação de imagens que indicam mobilidade (todas pertencentes ao imaginário marítimo): "redes de rezas", "campos convertidos em velas", "barcas sobrenaturais com peixes mensageiros" e "santos náuticos". Em todas elas, transparece um desejo de aproximação gradativo: primeiro, as rezas constroem redes para se comunicar com o passado, só depois os campos podem se transformar em velas e guiar "barcas sobrenaturais/ com peixes mensageiros", protegidas por "santos náuticos". Essa escolha representa, através da imagem do mar, a possibilidade de contato. O encantamento que Cecília sentia com as orações de sua avó aqui está contemplado e o que fora função da prece agora se torna função da poesia. A centralidade de Jacinta Garcia Benevides, a avó de Cecília, é bastante curiosa, essa figura materna e suas fabulações parecem funcionar como ponte para os assuntos que a poeta não podia acessar ou não conseguia entender. Sua importância será ressaltada novamente no fechamento de Mar Absoluto e outros poemas com o poema "Elegia", escrito em razão de sua morte, que analisaremos em nosso último capítulo.

A última estrofe dessa parte inicia-se com o atordoamento que transporta a poeta para as "praias tumultuosas". Essa realocação do sujeito funciona como um arrebatamento que a leva para mais próximo das "multidões passadas". Tamanha é a identificação que o leitor também consegue ouvir suas vozes em exaltação:

\footnotetext{
104 Cecília Meireles. Lição do poema, cartas de Cecília Meireles a Armando Côrtes-Rodrigues. Org. e notas, Celestino Sachiet. Ponta Delgada, Instituto Cultural Ponta Delgada, 1998, p. 64.

${ }^{105}$ Idem. p. 71. Conta Cecília Meireles que sua avó perdera um irmão afogado.
} 
"Para adiante! Pelo mar largo!

Livrando o corpo da lição frágil da areia!

Ao mar! - Disciplina humana para a empresa da vida."

A força desse chamado é poderosa, dado que o convite se estende ao leitor que também ouve o clamor, pela primeira e última vez no poema, dos mortos antigos. A navegação, na boca desses mortos, é o conhecimento humano para a realização da obra da vida, cuja trajetória eles tão bem dominam já que conheceram o fim da viagem. Nessa medida, (e aqui Cecília Meireles talvez se afaste da formulação pessoana) navegar é preciso porque viver é preciso. Em seu canto vemos que o largo mar se opõe à "lição frágil da areia”, de maneira que se livrar desta é condição para alcançar aquele.

A lição da areia pode ser entendida como um processo metonímico que irá desaguar na imagem da ampulheta e, por consequência, na própria ideia da fugacidade do tempo. Além disso, esse elemento ocupa o lugar entre a terra firme e o oceano, compartilhando atributos com ambos. Tem certa solidez, sobre a qual podemos até caminhar, contudo, como a água, não é capaz de reter marcas sob sua superfície, se moldando facilmente. A lição da areia é, de forma simultânea, a compreensão da irreparável passagem do tempo e a sensação do presente mais instantâneo, uma percepção temporal bastante humanizada. Isso porque a areia não simula, como a terra firme, o tempo estável e estéril da rotina e do suceder dos fatos que nos faz esquecer a morte. Mas também não é o "tempo inteiriço" do mar, no qual a totalidade nos faz navegar acima do tempo. É desta frágil lição, que nos determina como seres temporais e finitos, que a poeta precisará abdicar para dar continuidade à navegação.

A aproximação da multidão passada não trouxe para Cecília o reencontro com os mortos amados. Na verdade, esse chamamento anuncia algo mais amplo do que a navegação pelas origens familiares, uma vez que as vozes do passado querem comunicar a navegação como condição do destino. "Mar absoluto" não possibilitará, como veremos, o encontro afetuoso com os mortos, o seguir da navegante parece construir-se à medida em que as expectativas não se realizam, cada "fracasso" se abre como signo de algo maior e mais profundo, afinal, "poesia é só dar, é só perder”.

\subsection{Eu, Eles: Nós - o nosso mar}

A presença das "multidões passadas" foi aumentando paulatinamente no poema, por mais que o encontro de fato não aconteça. Elas foram vozes distantes, ocuparam as "praias 
tumultuosas" e de lá fizeram seus cantos de louvor à navegação. Agora, compartilham com a poeta a mesma vocação para o mar.

No entanto, a escolha pela voz coletiva (“queremos”) não significa a superação ou abdicação de uma viagem essencialmente solitária. Todos compartilham o mesmo destino, mas cada um segue seu próprio trajeto, afinal, uma das intenções da navegação é também atingir esse estado de solidão plena, "Queremos a sua solidão robusta,/ uma solidão para todos os lados". Aliás, a condição de viajante tem em si essa trepidação entre a companhia e a solidão, que no caso das viagens marítimas se vê potencializada pela impressão do interminável, vinda do mar - levando os homens a um movimento de interiorização. E será justamente por meio dessa "ausência humana" que a marinheira conseguirá atingir o "tempo inteiriço" do mar, libertando-se da mesquinha rotina mundana: "uma ausência humana que se opõe ao mesquinho formigar do mundo,/ e faz o tempo inteiriço, livre das lutas de cada dia".

Em "Mar Absoluto", o poeta vislumbra, a todo o momento, um percurso de incorporação do sujeito a algo mais amplo. Nessa terceira parte, o exercício de entrega, que antes era formulado como obrigação, se expressa como pacto através do sangue. Nas duas partes anteriores, a poeta parecia meio embriagada diante de seus deveres com o passado, agora, há uma espécie de reordenação em que a viagem passa a ser um projeto também pessoal.

Meu sangue entende-se com essas vozes poderosas.

A solidez da terra, monótona, parece-nos fraca ilusão.

Queremos a ilusão grande do mar, multiplicada em suas malhas de perigo.

O elemento que propicia a identificação é o sangue, no entanto, esse laço significará mais do que filiação parental, a identificação com a multidão passada virá mediante o desejo pelo mar com suas grandes ilusões e perigos. Esse caldo espesso, composto de água marinha e sangue, vai elaborar uma primeira assimilação, já que a partir desse verso (e durante toda essa terceira parte), Cecília não fará mais distinção entre $e u$ e o eles. Tal movimento de aproximação vem se alinhavando no poema através da ideia de destino, que fez a poeta chegar às "praias tumultuosas" e se unir às "multidões passadas" para iniciar a navegação, funcionando como mola para um sentimento de pertencimento a algo maior que o indivíduo. O gosto pela aventura a aproxima das vozes passadas e a diferencia dos demais homens que sentem o "alento heroico do mar" "seduzidos e medrosos", assustados frente ao mistério que se abre.

Por conta disso, o fundamental em Eu, eles: nós será a busca especulativa das especificidades do mar e da terra em comparação, já que seus contrastes vão caracterizando 
esse mar de aventuras para o qual a poeta se direciona. Enquanto a terra mostra-se "monótona", repetindo-se invariavelmente no mesmo "formigar" das gentes, o mar constitui-se principalmente pela sua diversidade e multiplicidade. Ambos oferecem à poeta uma ilusão que difere somente em relação à potência, uma vez que a terra "parece-nos fraca ilusão" e o mar oferece a grande ilusão, "multiplicada em suas malhas de perigo". E essa ilusão, que caracteriza tanto o mar quanto a terra, tem um significado ambíguo. Se pensarmos na sua composição com os respectivos adjetivos, podemos entendê-la de forma similar à palavra "fantasia". Nessa medida, a "fraca ilusão" da terra é a vida pouco interessante do cotidiano, que reduz os homens às suas obrigações, assim como, a "ilusão grande" do mar é a possibilidade de expansão e aventura trazida pela poesia e pela memória.

Contudo, se essa significação bastasse para a poeta e para a poesia, Cecília não deixaria “este mar visível” em busca de um Mar Absoluto, região onde não há espaço para ilusões. O adjetivo "absoluto" significa inalterado, uno, superior, ilimitado, formas sinonímicas de uma ideia de verdade e plenitude. A necessidade de rejeitar a ilusão, dando lugar a algo superior e até transcendente traz ao poema um importante impulso de idealização.

De acordo com Joseph Campbell, existe uma possível unidade no pensamento mítico oriental (e aqui o autor reúne a Índia, o extremo oriente, o Japão e a China), a semelhança viria justamente da crença num tempo cíclico que representa a eterna circularidade e transitoriedade da vida, fazendo com que o homem se veja obrigado a encontrar o eterno, o verdadeiro. Em cada religião (budismo, taoísmo, hinduísmo etc.), essa estrutura toma formas específicas, no Hinduísmo, por exemplo, temos o conceito de maya, que, de um modo amplo, pode ser traduzido por ilusão. Para um hinduísta, o exercício de reconhecimento e superação da maya é uma das maneiras de alcançar a glória e um estado divino de consciência.

A aproximação entre a ilusão ceciliana e a do pensamento hinduísta não é nada arbitrária, muito se tem estudado sobre os vínculos da poesia de Cecília com as doutrinas orientais $^{106}$. Dilip Loundo, em seu ensaio “Cecília Meireles e a Índia: viagem e meditação poética", traça de forma precisa a proximidade entre a poeta e, principalmente, Rabindranath Tagore e Mahatma Gandhi. Para o autor, a proximidade com a Índia não se restringe às questões de gosto ou à procura pelo exótico. Pelo contrário, essa aproximação é fruto de profundas

${ }^{106}$ Ana Maria Lisboa de Mello e Francis Utéza Oriente e Ocidente na poesia de Cecília Meireles. Porto Alegre, Libertos, 2006. 
leituras ${ }^{107}$ que fazem Cecília escolher o pensamento hinduísta como um espaço de reflexão, ao qual o imaginário poético recorre diante de alguns dilemas existenciais.

\begin{abstract}
Em que consiste esse caminho cognitivo? Consiste num método de desprendimento de todos os objetos empíricos - o "construir-se interiormente" - que, em lugar da evasão, significa proximidade epistemológica e envolvimento compassivo com os mesmos; e uma resolução metafísica consequente que, ao invés de um reino ontológico transcendente a este mundo, se instaura enquanto fundação - o "transmundo" -, a qual subjaz a todo e qualquer evento de percepção dos objetos para um eu. [...] Em suma, o lirismo maduro de Cecília Meireles reflete uma determinação qualificada de conhecer a totalidade de um mundo que se faz presente como ponto inicial e como destinação final (diferenciada) de sua jornada filosófica. ${ }^{108}$
\end{abstract}

Em "Mar absoluto", a busca da poeta se configura como uma espécie de "jornada filosófica" cíclica, que não almeja uma evasão para um mundo dos sonhos. E esse movimento cíclico faz a poeta retornar ao seu ponto de partida e encontrá-lo já diferenciado, ou, nas palavras do poema: "sobre-humano". O retorno e a ressignificação são formas de investimento nesse processo de construção do interior de que fala Loundo. Por essa razão, a ideia do mar enquanto “ ilusão grande”, que num primeiro momento é atrativa, será a razão de sua recusa e da escolha pela totalidade de um Mar Absoluto. A grande ilusão poderia trazer uma noção de tempo expandido, mais livre e móvel do que o tempo da rotina, que possibilitaria à Cecília o reencontro com o passado e uma abertura para as aventuras marítimas. Mas o que a poeta deseja é um tempo vazio ou inexistente, só está forma temporal a libertaria por completo da morte e dos fardos individuais.

\begin{abstract}
A existência no Tempo é ontologicamente uma inexistência, uma irrealidade. É nesse sentido que se deve compreender a afirmação do idealismo indiano e em primeiro lugar do Vedanta, de que o mundo é ilusório, [...] pois sua duração é limitada, e, na perspectiva do eterno retorno, é uma não-duração. Essa medida é irreal, não porque não exista no sentido próprio do termo, ou porque seja uma ilusão dos nossos sentidos; ela não é uma ilusão: nesse momento preciso ela existe - mas é ilusória na medida em que não existirá mais daqui a dez ou cem mil anos. O mundo histórico, as sociedades e civilizações, tudo isso é ilusório, pois, no plano dos ritmos cósmicos, o mundo histórico dura o espaço de instante. O vedanta, o budista, o rsi, o iogue, o sâdhu etc., tirando suas conclusões lógicas da lição do Tempo Infinito e do Eterno Retorno, renunciam ao mundo e procuram a Realidade Absoluta, pois somente o conhecimento do Absoluto os ajuda a se libertar da ilusão, a rasgar o véu de Mâya. $^{109}$
\end{abstract}

\footnotetext{
${ }^{107}$ Muitas aproximações podem ser feitas entre a série de poemas de Motivos da rosa e a obra Rubáiyát, de Omar Khayyám, homenageado no $3^{\circ}$ motivo da rosa. Principalmente no que se refere a uma concepção educacional e de esclarecimento sobre a profundidade da vida.

108 Dilip Loundo. "Cecília Meireles e a Índia: viagem e meditação poética.in Ensaios sobre Cecília Meireles, org. Leila Gouvêa, 2007. p.133, grifos do autor.

${ }^{109}$ Mircea Eliade. Imagens e Símbolos. Ensaios sobre o simbolismo mágico-religioso. Trad. Sonia Cristina Tamer. Editora Martins Fontes, São Paulo, 1996. P. 64
} 
O mito hindu de criação do universo, preservado no Brihadaranyaka Upanishad, nos ajuda a entender a relação entre o homem, o absoluto e a ilusão. Nessa gênese, o nascimento de tudo é derivado de uma cisão primordial: "this universe was nothing but the Self in the form of a man. It looked around and saw that there was nothing but itself, whereupon its first shout was "Its is I"" 110 . Depois de se saber "eu", este ser originário teve medo e começou a desejar mudanças, e assim se dividiu em homem e mulher, se fez natureza e os animais. É ao sentir a perda da unidade anterior que o ser passa a ter sentimentos e desejar, e, também, a se configurar enquanto parte, já não integrada no todo. O desejo é o atributo fundante desse novo ser partido, e tudo que ele almeja repercute na criação de novas realidades, sempre marcadas pela falta. Se na tradição bíblica, a queda dos homens de seu estado original e pleno se dá pela desobediência e o consequente pecado, no Hinduísmo, a queda não existe de fato, o que há é uma não percepção, em razão do desejo, do absoluto que constitui a todos:

As long as an illusion of ego remains, the commensurate illusion of a separate deity also will be there; and vice versa, as long the ideia of a separate deity is cherished, an illusion of ego, related to it in Love, fear, worship, exile or atonement, will also be there. [...] In the beginning, as we have read, there was only the Self; but it Said "I" (Sanskrit, aham) and immediately felt fear, after wich, desire. ${ }^{111}$

Cecília almeja esse retorno, esse estado de total integração, por isso o mar real - mesmo que tão vasto - não lhe baste. É preciso compreender que o múltiplo não existe, a realidade é o Absoluto por trás de tudo. E esse Absoluto não está na navegação pelas origens ou no projeto de destino e vocação para a aventura marítima. O mergulho da poeta nessa memória coletiva, que a fez se sentir parte dela, é ainda um vínculo de pessoalidade, pois de alguma maneira retoma aquela história de navegação em torno de seus avós e de sua grande família de navegantes. A "Realidade Absoluta" está afastada de qualquer noção pessoal ou temporal. No plano do Absoluto não há passado, presente ou futuro, por conseguinte, não há motivo para preocupação com as origens familiares.

Eu, eles: nós é o ápice de um percurso narrativo, que começou no início do poema. Esses três movimentos que viemos comentando estão muito calcados no resgate das origens, na ideia de destino e de projeto coletivo, nas histórias ouvidas durante a infância e noutros temas de natureza poético-biográfica. Mas algo distinto se configura aqui: a assimilação das vozes antigas e o início de uma flexibilização do eu. A dissolução do eu é a tarefa que converte o príncipe Siddhartha Gautama em Buda. No Budismo também, a subjetividade é algo danoso e

${ }^{110}$.Joseph Campbell. The Masks of God-Oriental Mythology. Nova York, The Viking Press, 1962. p. 14.

${ }^{111}$ Idem. Ibidem. 
ilusório, que deve ser abolida para alcançar a ascensão e o conhecimento verdadeiro sobre unidade absoluta do universo.

Para buscar a libertação, o futuro Buda escolhe a meditação em baixo de uma árvore sagrada, onde foi testado em suas fraquezas. Cecília opta pelas complexas águas marinhas, que lhe apresentarão o desafio de entender a unidade dentro do difuso.

\subsection{Conhecendo o mar - o caminho dos contrários}

O encontro com o mar é uma espécie de exercício suprassensível de descrição de um objeto. Talvez por isso seja um dos momentos mais belos do poema, dado o constante movimento entre imagens contrastantes, que a cada momento representam um novo mar, nos fazendo ver a diversidade de elementos que tecem as "malhas de perigos" das águas marinhas. Aqui não teremos a presença dos fantasmas de antepassados, companheiros dessa travessia. $\mathrm{O}$ verso de abertura "O mar é só mar, desprovido de apegos" deseja essa "ausência humana", uma limpeza dos estímulos externos para que o mar seja entendido em si mesmo. A intenção descritiva é tão vasta que essas estrofes são predominantemente nominais, em forte oposição à parte anterior em que a poeta animara-se com o convite e exortava a navegação ("Queremos a ilusão grande do mar"; "Queremos a sua solidão robusta" etc.). Agora, a poeta lança mão de verbos de ligação, gerúndios e particípios, construindo a curiosa e apropriadíssima sensação de uma imobilidade que se move, tão própria ao mar ("correndo como um touro azul por sua própria sombra"; "ele que, ao mesmo tempo,/ é o dançarino e a sua dança." etc.).

O recado da multidão passada, em Eu, Eles: Nós, acalmou a poeta, que agora já não precisa navegar direcionada pela missão de resgatar os mortos, e a narração em busca do destino dá espaço à descrição da experiência. Por essa razão, toda a forte carga biográfica e emocional das partes anteriores se liquefaz, restando a sensação do homem diante do interminável. Sensação semelhante àquela que nos transmite a pintura a óleo de Caspar David Friedrich, "Viajante sobre o mar de névoa" (1818). Nela vemos um homem de costas contemplando um mar de névoa tão grande que não se pode distingui-lo das montanhas ao fundo, o ímpeto desbravador é tamanho que transborda a ponto de também constituir a postura do viajante. As razões que assolam o homem contemplativo são diferentes no poema e na pintura, o homem de Friedrich tem uma postura altiva, talvez daquele que poderá dominar a força assombrosa da Natureza, a poeta, em contraste, vai, a cada novo verso, derramando-se e diluindo-se na complexa substância marítima. 
A representação do mar ceciliano será labiríntica e capaz de reunir uma grande variedade de elementos. Dessa agregação de coisas nascerá uma espécie de unidade, constituída a partir de dualidades: um touro azul correndo por sua própria sombra, "o dançarino e sua dança", "cavalo épico, anêmona suave", "grandeza despojada" etc. A beleza dessas imagens está em sua tensão constitutiva, que vai dando rosto às águas marinhas graças à justaposição de metáforas de movimento entre signos contrastantes (cavalo; anêmona/ grandeza; despojamento) ou duplos (touro; sombra/ dançarino; dança). Em suas metamorfoses constantes, o mar nos ensina que seu objetivo não está na fixação dos extremos, seu rosto não é só o "touro azul" ou a "anêmona suave", o propósito de seu jogo eterno é matar-se e recuperar-se:

Cecília Meireles opera as oposições como técnica dos adynata, coisas impossíveis, como as daqueles versos de Camões sobre o amor, "fogo que arde sem se ver", "ferida que dói e não se sente" etc. As oposições efetuam a despersonalização do $e u$, a desmaterialização das coisas e a abstração das significações; com isso também o vazio na cabeça do leitor, lançado dentro do mar sempre recomeçado da poesia. ${ }^{112}$

O que Hansen enxergará como operação de oposições (os adynata), entenderemos enquanto busca de uma unidade transcendente. Os paradoxos desta quarta parte resultam na despersonalização do sujeito e na desmaterialização das coisas, como indicou o crítico, mas eles nascem de um esforço de agregação total, ou melhor, nascem do desejo pela não distinção. Se Camões operava oposições para precisar as emoções que constituem a complexa natureza do amor, Cecília as aproxima a fim de diluir seus contrastes. Mircea Eliade entende, dentro de seus estudos sobre mitologia comparada, que o desafio de eliminar polaridades é justamente parte da marcha dos homens à elevação espiritual, visto que aboli-las é de alguma forma superar a condição humana (vida e morte) para alcançar a transcendência.

Todo simbolismo da transcendência é paradoxal e impossível de se conceber no plano profano. O símbolo mais usado para expressar a ruptura dos níveis de penetração no "outro mundo", no mundo supra-sensível (seja ele o reino dos mortos ou dos deuses), é a "passagem difícil", o fio da navalha. "É perigoso passar pela lâmina afiada de uma navalha, dizem os poetas para expressar as dificuldades do caminho (que leva à sabedoria suprema)", afirma Katha Upanishad (III, 14). Lembramo-nos do texto do Evangelho: "Estreita é a porta e apertado é o caminho que conduz à Vida, e como são poucos os que o encontram" (Mateus,7, 14). Aliás, a "porta estreita", o fio da navalha, a ponte estreita e perigosa não esgotam a riqueza desse simbolismo. ${ }^{113}$

112 João Adolfo Hansen. “A vida reinventada”. Apresentação à edição de Mar absoluto e outros poemas, Editora Global, 2015, p.13-22.

${ }^{113}$ Mircea Eliade. Imagens e Símbolos. Ensaios sobre o simbolismo mágico-religioso. Trad. Sonia Cristina Tamer. Editora Martins Fontes, São Paulo, 1996, p. 80. 
Quando a poesia de Cecília Meireles busca a transcendência, ela o faz através de dualidades, que não necessariamente são antitéticas mas sempre criam uma ideia paradoxal ou fantástica. O mais belo exemplo disso em Mar absoluto e outros poemas é "Lamento da mãe órfã", em que o filho perdido é chamado de volta à vida pela saudosa mãe que lhe propõe: "Vem como estás, metade gente, metade universo, ${ }^{114}$ ". A conciliação do corpo apodrecido do filho ("Não te envergonhes de teu cheiro subterrâneo,/ dos vermes que não podes sacudir de tuas pálpebras,") com seu regresso é uma proposição de transcendência. A unidade possível nasce, então, da conciliação de impossíveis, da mesma forma que no mar de "Mar absoluto", já que ele é o "reino de metamorfose", terreno que amalgama o que na terra firme se diferencia.

O processo descritivo dessa quarta parte pode ser entendido como um empreendimento da consciência (por mais que seu movimento pareça pertencer ao mundo do sonho). Há rigorosidade na organização dos paradoxos que não parecem ser fruto de uma acumulação caótica e livre de ideias. A base desse rigor concentra-se em duas frentes principais, a primeira delas diz respeito à aposta na unidade mesmo dentro do difuso, de que falamos acima. A segunda, às imagens selecionadas pela poeta que compõe uma unidade quanto à ideia de movimento: o dançarino, o touro, o cavalo, a anêmona, todos são figuras totalmente dependentes do mover-se.

A primeira estrofe desta parte é bastante plástica e tem um colorido vibrante. A delicadeza do desapego marítimo, presente nos dois primeiros versos, choca-se com a paixão brusca que viria através da figura do touro:

O mar é só mar, desprovido de apegos, matando-se e recuperando-se, correndo como um touro azul por sua própria sombra, e arremetendo com bravura contra ninguém, e sendo depois a pura sombra de si mesmo, por si mesmo vencido. É o seu grande exercício.

Contudo, o fantástico "touro azul" é utilizado com certo deslocamento, toda a virilidade esperada do animal é desmanchada pelo seu exercício inútil de "arremeter-se contra ninguém" e tornar-se pura sombra de si mesmo, emulando a própria trajetória da onda, em seu eterno fazer-se e desfazer-se. Seu movimento febril e estéril acaba por descrever que o processo de renovação marítima vem do exercício de dobrar-se sobre si mesmo. A poesia de Cecília não lê

\footnotetext{
${ }^{114}$ Cecília Meireles. Obra poética. "Lamento da mãe órfã", (Mar absoluto e outros poemas). Editora José Aguilar, Rio de Janeiro, 1958. p. 366.
} 
violência nesse movimento, como fizera Valéry, em "O cemitério marinho", o mar ceciliano é o terreno da mutabilidade de tudo e essa especificidade é aceita com uma suave demissão.

No poema de Valéry, o movimento do mar é visto como angustioso combater-se.

\section{$[\ldots]$}

Sim! Grande mar de delírios dotado, Pele de pantera, manto rasgado É por mil ídolos do sol ferido, Ébria da carne azul, hidra absoluta Que em luz a própria cauda morde e luta Num tumulto ao silêncio parecido, ${ }^{115}$

$[\ldots]$

O "touro azul" de Cecília se diferencia da "hidra absoluta" de Valéry, composta por delírios e feras. Em "O cemitério marinho", o sentimento preponderante é a violência e a fúria; desta maneira, para representar o contínuo movimento das águas, o poeta faz sua hidra morderse a si mesma como garantia da eternidade, representando assim um mar cujo exercício fundamental é a luta. Apesar do poema de Valéry sugerir no título a ideia da morte, o mar nele representado é dotado de grande vitalidade, chegando até mesmo a ter carne, "Ébria da carne azul", como os homens e os animais. Não há esse ímpeto de combate ou essa materialidade, própria dos corpos vivos, nos versos de "Mar absoluto". Na figura do "touro azul" que se desmancha em "pura sombra de si mesmo", Cecília propõe um mar em que as fronteiras se desmanchem, além de atenuar qualquer ideia de materialidade.

Baralha seus altos contrastes: cavalo épico, anêmona suave, entrega-se todo, despreza tudo, sustenta no seu prodigioso ritmo jardins, estrelas, caudas, antenas, olhos, mas é desfolhado, cego, nu, dono apenas de si, da sua terminante grandeza despojada.

Ao embaralhar os contrastes marítimos, a poeta quer deflagrar a multiplicidade, sem indicar fraturas, fazendo com que seu mar abarque todas as coisas e as preserve em suas particularidades. É como se a cada nova onda, o mar nos mostrasse uma nova faceta, indo desde as narrativas heroicas (“cavalo épico") até a miúda natureza marinha (“anêmona suave”), tudo imerso em suas salgadas águas. A beleza de seu mar está nessa capacidade delicada de ser e deixar todas as coisas sem feri-las ou descaracterizá-las. Esse exercício mantém os “jardins,

${ }^{115}$ Paul Valéry. O cemitério marinho. Trad. Jorge Wanderley. 2a Ed. Editora Max Limonad, São Paulo, 1984. 
estrelas, caudas, antenas, olhos" num estado de suspensão que, de alguma forma, os eterniza em sua fluidez. Em "Naufrágio antigo"116, de Vaga Música, observamos um procedimento similar, a inglesinha que morrera afogada se vê, apesar de deteriorada pelo tempo, preservada em seus sentidos e sentimentos.

$[\ldots]$

A cor dos planetas pinta seu rosto de cera e banha seus pensamentos.

(Porque ela ainda pensa: algas pelo ventre, azuis e verdes, medusas pelos artelhos.

E ainda sente.

Sente e pensa e vai serena, embalada em seus cabelos.)

$[\ldots]$

O mar ceciliano mantém e ampara todos os seres que ocupam seu interior ("antenas" e "caudas"), os astros do céu ("estrelas"), a natureza civilizada ("jardins") e os homens que o contemplam ("olhos"). É a centralidade criadora e mantenedora da vida e o caminho possível para tentar reencontrar os mortos. Nos versos de "Aceitação", em Viagem, o oceano aparece como o lugar do "nascimento mudo das formas". Contudo, a grandiosidade não the garante poder tirânico por ser "desfolhado, cego, nu, dono apenas de si,/ da sua terminante grandeza despojada.". O simbolismo de ascensão da condição humana em "Mar absoluto" está nessa força líquida que se configura na relação dialética entre o exercício de desprendimento marítimo e sua capacidade de eternizar seus objetos de seleção: “água de todas as possibilidades,/ mas sem fraqueza nenhuma". Atitude que pode ser entendida com perfeição pelos versos do " 4 " motivo da rosa", já citado anteriormente, poema em que o empenho é reconhecer o deixar de ser enquanto forma de estar no mundo: "Não te aflijas com a pétala que voa:/ também é ser, deixar de ser assim".

Margarida Maia Gouveia nomeia esse procedimento de aproximação de pares contrários de discurso do paradoxo ${ }^{117}$. A crítica percebe que esse exercício contrastante poderia resultar em cisão, contudo ele só faz deflagrar unidade. Os substantivos que vão constituindo o mar

114 Cecília Meireles. Obra poética. "Naufrágio antigo", (Vaga Música). Editora José Aguilar, Rio de Janeiro, 1958, p. 238-239.

${ }_{117}$ Margarida Maia Gouveia. Cecília Meireles: uma poética do eterno instante. Editora Imprensa Nacional-Casa da Moeda, 2002. p.142. 
ceciliano (touro, sombra, dançarino, dança, cavalo, anêmona, jardins, antenas, caudas, olhos) perdem parte de sua natureza concreta para funcionarem como elementos conjuntivos que recriam uma "espécie de espaço único que conjuga o mundo, os sentimentos e a linguagem"118

Cecília, a partir da reflexão contemplativa, identifica no mar uma imperiosa habilidade de, ao mesmo tempo, saber fluir e por isso permanecer. O poema vinha até então calcado numa sensibilidade que desejava atingir a permanência e acabava, invariavelmente, se deparando com a finitude; a própria navegação surge pela constatação dessa finitude e pelo anseio de reencontrar os mortos amados. Contudo, o mar descoberto em Conhecendo o mar se mostra uma nova possibilidade para viver e compreender o vazio embutido no núcleo de todas as coisas.

\subsection{Búzios da lembrança - o novo trajeto}

Como já comentamos, o exercício de ressignificar a missão enviada pelas "multidões passadas" funciona como degrau para uma ampliação das perspectivas poéticas e ontológicas. Primeiro houve a renúncia ao projeto personalista em torno do resgate da família e, agora, o abandono da aventura para selar um pacto de conversão com o mar. As razões da impossibilidade da primeira já foram discutidas nesse trabalho; quanto à segunda, sua frustração nasce do exercício de observação comentado em Conhecendo o mar. A aproximação fez a poeta abandonar o desejo aventureiro, porque o mar que se apresentava pareceu-lhe tão complexo que a única investida possível era aquela que o entendesse como um fim em si mesmo.

O processo de transformação é iniciado com uma personificação e o mar passa a se comunicar diretamente com a poeta:

E assim como água fala-me.

Atira-me búzios, como lembrança de sua voz, e estrelas eriçadas, como convite ao meu destino.

Ao falar como água, o mar opta por uma linguagem fluida e contínua, sem brusquidão, todavia não por isso mais frágil. Por conta disso, para se comunicar, o mar fará uso de figuras simbólicas, o primeiro signo que a poeta recebe é o búzio: “Atira-me búzios, como lembrança de sua voz". Essa palavra tem por significado ouvidos (no sentido de parte do corpo que nos faz ouvir) e concha. Mais especificamente, um tipo determinado de concha usada como apito

\footnotetext{
${ }^{118}$ Idem. Ibidem. p. 151
} 
para a comunicação entre pescadores ${ }^{119}$. De ambas as formas, a ideia do búzio está atrelada ao sentido da audição, isso também pode ser pensado sobre as conchas em geral, que, de acordo com o gosto popular, trazem o ressoar do mar dentro do si. As conchas chegam até a poeta como lembrança, elas ecoam o chamado do mar e sinalizam uma nova empreitada.

Depois das conchas sonoras, o mar envia "estrelas eriçadas" que são sinais de direção ao novo destino. O desenho da capa da primeira edição de Mar absoluto e outros poemas, de Maria Helena Vieira da Silva, é precisamente um delicado barquinho sendo guiado por uma estrela. $\mathrm{O}$ desenho não tem excessos e ilustra somente o pedaço do mar em que o barco se encontra e a estrela lhe indicando o caminho. Por conta dos poucos elementos, cada um chama para si muita atenção e o sentimento que governa a gravura é o de destinação e solidão, representando os homens que se abandonam diante de um projeto maior que suas individualidades. A condição solitária do homem é um tema compartilhado por Vieira da Silva e Cecília Meireles, a pintora também fora uma menina solitária, como conta Valéria Lamego em "Dois mil anos no deserto: Maria Vieira da Silva no Rio de Janeiro 1940-1947" ${ }^{120}$. Talvez essa vocação para a solidão a tenha feito, logo no começo de sua carreira, preferir "desenhar figuras muito pequenas, mínimas, em folhas gigantescas" ${ }^{121}$, estilo que retorna na capa de Mar absoluto e outros poemas, na qual o desenho ocupa somente a parte de baixo.

Vieira da Silva, junto de seu marido Arpad Szenes, fez painéis para a Escola Nacional de Agronomia, no Rio de Janeiro. Entre os azulejos e retratos de cientistas que compõem a obra, nomeada "Quilômetro 44", encontramos também a representação de um barco no mar. Porém, no mural da escola, a solidão e a ausência não são temas centrais. Há vida e maior riqueza de elementos: os pescadores, os peixes, os pássaros, os artefatos de pesca e as estrelas, que estão tanto no mar quanto no céu. A comparação ajuda a perceber o quanto Vieira da Silva desejou retratar, na ilustração da capa da obra ceciliana, a solidão de um barco sem tripulantes e que mal toca o mar.

No desenho da capa de Mar absoluto e outros poemas só é representado o essencial, o barco sem tripulantes navega a gosto do vento, tendo ao horizonte uma única estrela. A sensibilidade da artista descreve a postura essencialista de Cecília, preocupada com os grandes assuntos humanos, fora do cotidiano. De tal maneira que da atividade (a navegação) é retirada toda referência do rotineiro, essa "limpeza" acaba construindo não uma figura concreta, como

119 "Búzio. (Do lat. Bucina, "trombeta”) S. m. 1. Bras. Designação comum às conchas de moluscos gastrópodes, nas quais sopram os pescadores e os jangadeiros para anunciar sua chegada ao porto ou transmitir notícias do mar." In FERREIRA, Novo dicionário de língua portuguesa. Nova Fronteira.

${ }^{120}$ Vieira da Silva no Brasil. Concepção de Nelson Aguilar. Museu de Arte de São Paulo, 2007, p. 53- 71.

${ }^{121}$ Idem. Ibidem. P.57. 
o fora no painel, mas uma ideia abstrata: representando não só a navegação, mas a trajetória da vida humana.

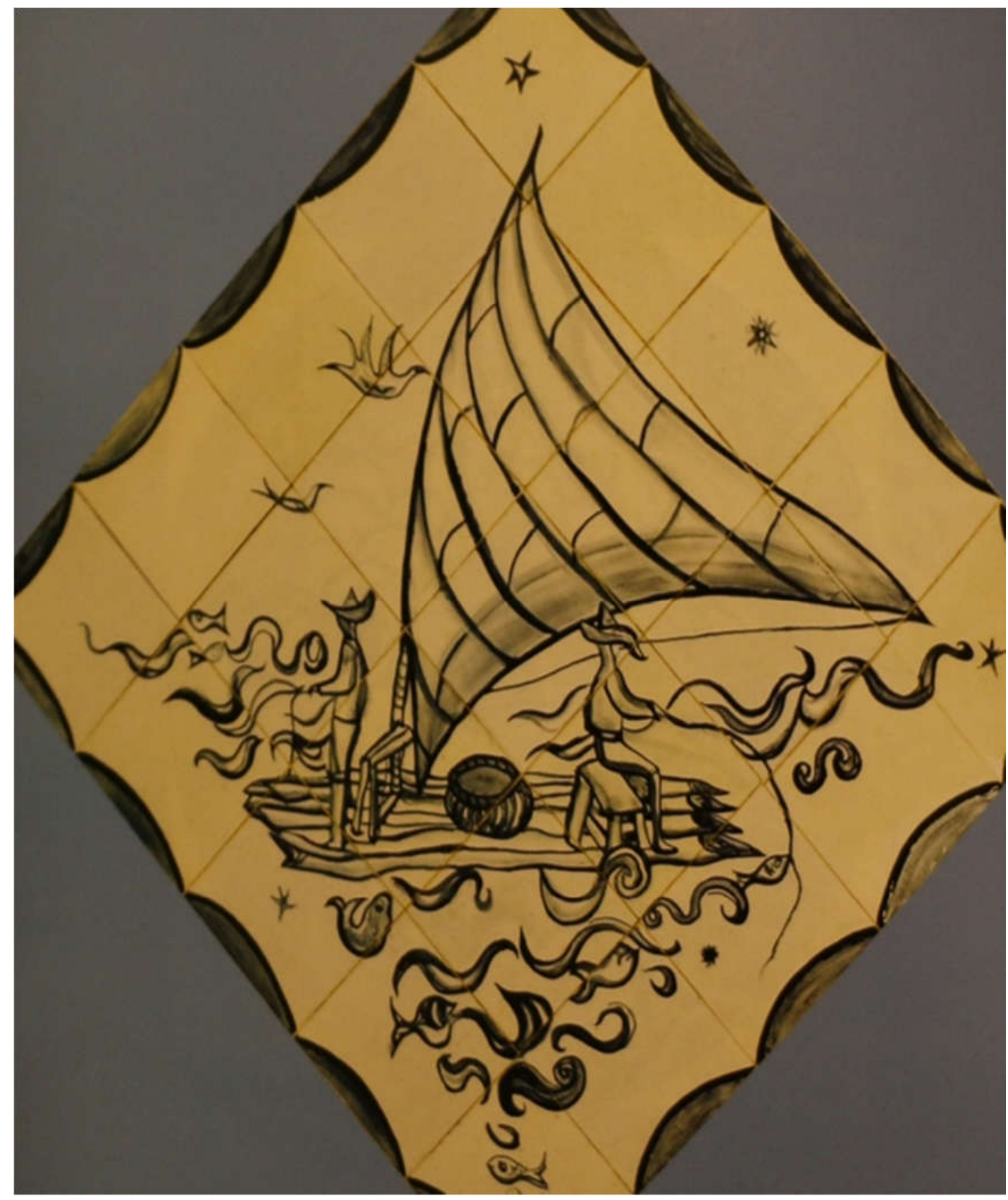

Fotografia retirada de Vieira da Silva no Brasil. Concepção de Nelson Aguilar. Museu de Arte Moderna de São Paulo, 2007. p. 6. 


\section{CECILIA MEIRELES}

\section{MAR \\ absoluto \\ e outros poemas}

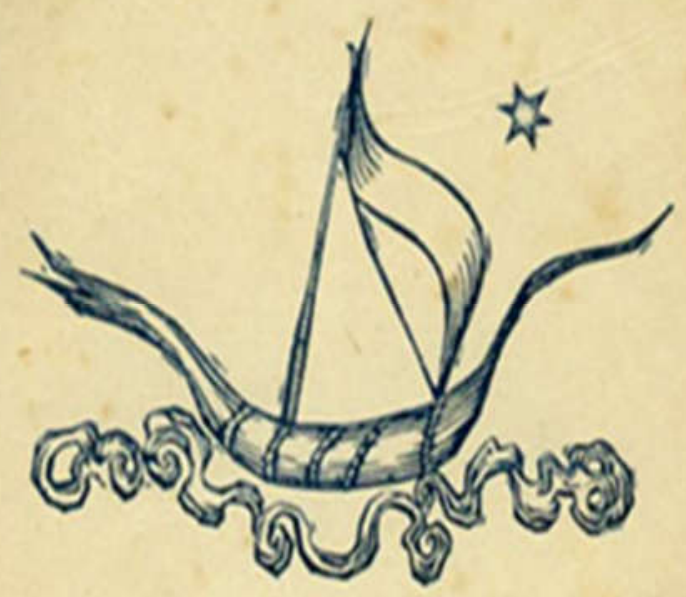

EDICÃO DA

LIVRARIA DO GLOBO

Fotografia da capa da primeira edição de Mar absoluto e outros poemas, 1945, com a ilustração de Vieira da Silva. 
Na poesia de Cecília, a observação dos astros é bastante importante, nesse terceiro livro há diversos momentos de contemplação do céu noturno, principalmente da lua. E nos poemas marítimos temos a constante presença das estrelas - "Quero silêncios de estrelas,/ voz sem promessas do mar." ${ }^{122}$, únicos elementos que podem guiar a poeta em sua navegação noturna. De modo que a busca e o reconhecimento do destino parecem sempre atrelados à introspecção meditativa do sujeito, apesar de serem motivados por elemento externos: vozes de multidões passadas, estrelas, conchas etc. Os chamados externos intensificam ainda mais a questão da destinação intransponível, já que até a própria natureza apelará para ação da poeta. Contudo, apesar de fortemente dependente de fatores exteriores, o poema nasce do estudo da solidão e da reflexão, porque para Cecília o exercício de compreensão do mundo e de si só parece possível em face de uma postura solitária e reflexiva.

Toda a cena construída pela "fala" do mar é bastante animada. O uso do adjetivo “eriçadas" dá movimento à representação das estrelas que se levantam no céu noturno como as velas de um barco. Da mesma forma, o verbo "atirar" faz com que os búzios sejam lançados para a poeta, tais como as âncoras que a convidam para nova embarcação. Toda essa movimentação sugere uma natureza viva que acaba tendo o formato de um grande navio - o próprio mar é este navio, seu corpo e seu movimento vão tomando a forma de um grande barco que navegará pelo Absoluto.

Como sua comunicação é essencialmente simbólica, a poeta deve manter seus sentidos e atenção aguçados para saber ler estrelas, búzios, ondas, areias, sempre entendendo que o significado dos objetos e seres está além de suas figuras objetivas e concretas. Diante do mistério que envolve todas as coisas, conchas não são só conchas, são apitos que chamam a navegante para uma aventura ainda maior, e a beleza das estrelas não é só sua incrível luz que chega aos nossos olhos, mas é o misterioso dom de nos conduzir dentro da noite escura. O leitor de Cecília deve aceitar que em sua poesia as imagens e as ideias não querem se entregar com facilidade, porque sua beleza está no reconhecimento daquilo que não se alcança: "As palavras aí estão, uma por uma:/ porém minha alma sabe mais. [...] Falai! meu mundo é feito de outra vida." ${ }^{123}$.

Todos os signos que o mar envia querem explicar para a poeta que seu trajeto não é o da simples navegação sobre as águas, mas é um processo de transformação do sujeito, por isso a escolha pela palavra "conversão" é bastante significativa nesse poema. A priori, pelo seu

${ }^{122}$ Cecília Meireles. "Canção", Obra poética (Mar absoluto e outros poemas). José Aguilar, 1958. p. 324.

123 Cecília Meireles. "Interpretação", Obra poética (Mar absoluto e outros poemas) José Aguilar, 1958. p. 362. 
costumeiro uso em contexto religioso (de converter-se a esta ou àquela fé) e depois pela ideia de movimento circular. Como se sabe, conversão vem da palavra latina conversio, que pode significar mudança, metamorfose, como também, giro ou movimento circular. O que nos leva a pensar numa transformação em torno de seu próprio eixo, ou melhor, na identificação da mudança a partir do olhar para si mesmo. Tão significativa é essa ideia de retorno que a poeta, logo após o convite à conversão, retoma os tios e os avós (que povoaram as partes iniciais do poema) - como se olhasse para trás e vislumbrasse a importância de suas origens pessoais para o reconhecimento desse destino mais amplo:

Não me chama para que siga por cima dele, nem por dentro de si: mas para me converta nele mesmo. É o seu máximo dom.

Não me quer arrastar como meus tios outrora, nem lentamente conduzida, como meus avós, de serenos olhos certeiros.

A poeta compreende que sua relação com o mar não é a esperada, novamente. Ela não será a navegante ("Não me chama para que siga por cima dele") ou a afogada ("nem por dentro de si”). Seu destino marítimo também não equivale ao de seus familiares, já que o mar não deseja levá-la pela vida até o envelhecimento ou ceifá-la de forma brusca. Ele a quer como igual: "plástica", "fluida", "em constante solilóquio", "sem exigências de princípio e fim", “desprendida de terra e céu”. Essa proposta de conversão não é algo simples, a poeta abandonará a subjetividade tornando-se a substância que detém em si toda a vida. Essa diluição certamente confirma um desejo de superação da condição humana que veio alimentado pelo recado das "multidões passadas" (a "lição da areia") e também pelo complexo movimento marinho.

Por conta disso, a poeta não fará a viagem que culminará nos afogamentos ou nas derivas, o pacto de entrega e afeto, se comprometerá a fazer de sua vida o mesmo jogo resignado e inútil de dissolver-se em si mesmo.

\subsection{O outro mar - nas voltas do Absoluto}

A última parte de "Mar absoluto" funciona como uma "terraplanagem" da viagem acontecida até agora, no sentido de nivelar a experiência, dar-lhe um chão. Ao retomar o vivido, o sujeito experimenta uma espécie de reconhecimento seguido por um prazer conclusivo, que ressignifica o percurso e se abre para uma nova sorte de acontecimentos. Como dissemos no 
início desse ensaio, "Mar absoluto" é um poema que retrata uma viagem, mas uma viagem muito introspectiva, guiada predominantemente por dilemas biográficos e existenciais. Em $O$ outro mar, presenciamos uma razoável viragem dessa tendência e a atitude da poeta será, inicialmente, a de uma reflexão mais objetiva e racional sobre o experimentado. Isso porque essa sexta parte representa um retorno - de dentro para fora -, toda a viagem interior que havíamos acompanhado se paralisa e encontramos Cecília novamente fitando o mar.

Depois de ter-se entregue às paradoxais águas, a poeta pôde compreender que sua peregrinação para resgatar os mortos fora um engano:

E eu, que viera cautelosa, por procurar gente passada, suspeito que me enganei, que há outras ordens, que não foram bem ouvidas; que uma outra boca falava: não somente a de antigos mortos, e o mar a que me mandam não é apenas este mar.

Em meio às vozes antigas, havia uma outra boca que também falava e não era percebida: a voz do próprio mar também lhe dava um direcionamento. A conversão na densa amálgama marinha lhe possibilitou uma escuta interna, mais atenta e sensível, e disso nasce o reconhecimento de uma nova missão. Cecília ainda buscará o mar, mas não aquele mar que "reboa nas minhas vidraças".

Não é apenas este mar que reboa nas minhas vidraças, mas outro, que se parece com ele como se parecem os vultos dos sonhos dormidos. E entre água e estrela estudo a solidão.

O apelo à teoria da representação platônica é atraente para pensar a relação entre este mar que é como os "vultos dos sonhos dormidos" e aquele que virá a ser o Mar Absoluto. A sugestão é fácil de se justificar, aparentemente Cecília também cria níveis de representação cujas derivações estão mais ou menos próximas de um ideal. Nessa medida, e pensando nos exemplos usados por Platão, o mar visível é imagem refletida no espelho que mira para um mar total, ideal. O que parece diferenciar o pensamento ceciliano do platônico é a fixação, em um eixo vertical, de derivações possíveis. Para o filósofo, os níveis não se misturam e à medida que nos afastamos do ideal, o conteúdo original sofre degradações. Apesar de também vermos uma distinção entre o Mar Absoluto e o mar visível, sua diferenciação não nos parece seccionada de forma rígida. Na verdade, um parece estar contido no outro, assim como estivera no mar visível, o "touro azul", a "anêmona suave", "cavalo épico", o dançarino, os "jardins", as "antenas", os 
“olhos". Essa distinção não é banal porque ilumina um idealismo específico, que parece acreditar na inteireza eminente de todas as coisas, que estão sempre prontas para desabrochar em sua forma plena ou absoluta:

E recordo minha herança de cordas e âncoras, e encontro tudo sobre-humano.

E este mar visível levanta para mim

uma face espantosa.

E retrai-se, ao dizer-me o que preciso.

E é logo uma pequena concha fervilhante, nódoa líquida e instável, célula azul sumindo-se no reino de um outro mar: ah! do Mar Absoluto.

O encontro com o absoluto é novamente entremeado pela ideia de destino. A repetição exata da palavra "recordo" faz com que também recordemos que esse poema teve início graças ao ímpeto apaixonado de um sujeito para resgatar seus mortos ("minha herança de cordas e âncoras"). Mas essa segunda recordação não retoma os elementos do passado a fim de perseguilos e alcançá-los, pelo contrário, ela os aceita como componentes de um estágio de percepção. A retomada dos antepassados é também uma maneira de reconhecer o destino e validá-lo, aceitando que o encontro do absoluto só é possível para aquela que parte buscando o que lhe falta, encarando suas faltas e silêncios.

A fala final do mar vem de um movimento de retração profundo e intenso, como se uma grande onda fosse arrebentar na explosão da verdade marítima. Mas a poesia de Cecília não é dada a explosões, a força natural do mar é atenuada a partir de novo distanciamento do sujeito. A poeta que se encontrava novamente observando o mar, talvez de sua janela em frente à praia, recua a tal ponto que o oceano se transforma numa "pequena concha fervilhante", "célula azul sumindo-se". Esse novo arrebatamento da consciência dilui totalmente a realidade num azul maior que o mar: em uma nova viagem que não conhecemos e que finaliza o poema com um sentimento de incerteza sobre aquilo que se abre e não vemos. A escolha de não indicar com clareza essa nova missão é bastante acertada, com isso Cecília finaliza o poema com a maior elevação possível, semelhante àquela do trapezista antes do grande salto, quando o corpo já nem está firme pelo apoio do chão, nem desliza pelo ar.

\subsection{A procura do vazio}


"Mar absoluto" se inspira nos poemas de navegação para nos contar a história de uma espécie de herói lírico que se dissolve, depois de certa peregrinação, nas complexas águas do Absoluto. Nele vimos o seguinte percurso: uma vivência do presente desperta na poeta uma recordação do passado, da qual surgirá o motivo da viagem/poesia: começa então um constante movimento de ressignificação da viagem que só encontrará repouso na visão do Mar Absoluto. A questão mais importante que se impõe à tarefa crítica é compreender como e porquê o sujeito aceita e deseja o processo de esvaziamento de si e de superação da condição humana, entregando-se completamente ao Mar Absoluto.

Como observamos durante a análise, o Mar Absoluto é o território, ao mesmo tempo, do vazio e da totalidade, equivale, em certa medida, àquele estado pleno do deus hindu antes de começar a ter desejos e se dividir. Se a noção da identidade e seus consequentes desejos são o caminho do sofrimento, o esforço de libertação da dor vem no sentido da eliminação de quaisquer tipos de identificações com o $e u$, sejam espaciais, temporais ou afetivas. É por essa razão que, depois de reconhecer a ausência que lhe ecoava através das vozes do passado, a poeta investe num progressivo movimento de negação e num esforço de ressignificar a falta original. O ritmo afoito que compõe os versos dá corpo a esse desejo, a repetição constante da conjunção aditiva "e" evidencia a pressa e a ansiedade que só encontraram descanso no Absoluto, expressado pelo suspiro do último verso: "ah! do Mar Absoluto". A bússola que guia o poema tem como norte um aliviamento da mesma tensão que o gera, uma vez que nele o passado se apresenta como força coerciva ("E multidões passadas me empurravam") que precisa ser satisfeita.

A escolha pelo Absoluto pode, então, representar uma maneira de reformular as experiências de sofrimento, já que sua nulidade total alivia o peso subjetivo. Como explica Freud, em seu famoso ensaio “Além do princípio do prazer", nossa vida psíquica tende a buscar uma menor excitação, num complexo empenho de retornar à quietude do mundo inorgânico. No caso do poema analisado, a ansiedade pelo reencontro com os familiares e a frustração por sua impossibilidade encontram apaziguamento no Absoluto, ou, como também poderíamos formular, na perda total, no vazio anterior ao desejo.

Todavia, o poema não se resume às questões autobiográficas, como já dissemos, ao erigir os símbolos de sua família (“cordas e âncoras") a patamares "sobre-humanos", a poeta nos sugere que a superação do luto vivida em "Mar absoluto" tem ainda nuances coletivas, funcionando como um mapa da experiência humana vitoriosa sobre a dor e os dissabores. "Mar absoluto" é um poema de abertura bastante diferente daqueles de Viagem (1938) e Vaga Música 
(1942), cujos poemas iniciais são curtos, metalinguísticos, impessoais (mesmo que usando a primeira pessoa), guiados por uma suave melancolia e por um movimento delicado que, verso a verso, vai apontando para um sentimento de efemeridade:

Pousa sobre esses espetáculos infatigáveis uma sonora ou silenciosa canção:

flor do espírito, desinteressada e efêmera.

Por ela, os homens te conhecerão:

por ela, os tempos versáteis saberão

que o mundo ficou mais belo, ainda que inutilmente, quando por ele andou teu coração ${ }^{124}$.

O ritmo em que gemo

doçuras e mágoas

é um dourado remo

por douradas águas.

Tudo, quanto passo,

olha-me e suspira.

- Será o meu compasso

que tanto os admira? ${ }^{125}$

Em "Epigrama n ${ }^{\circ} 1$ ", a negatividade da condição humana afirma-se pela efemeridade da vida. Mesmo que a canção garanta à poeta certa imortalidade ("por ela, os tempos versáteis saberão"), sua beleza é inútil. Essa marca melancólica retorna em "Ritmo", principalmente por meio do movimento contínuo da poeta que passa gemendo suas doçuras e mágoas. Em nenhum deles a transitoriedade transfigura-se em algo mais amplo e a atitude da poeta concentra-se em constatá-la com alguma mágoa. A passagem da constatação dolorosa do efêmero para o encontro de êxtase com o absoluto, acreditamos, tem importante relação com o tempo histórico em que a obra foi escrita. Em um delicado ensaio intitulado "Transitoriedade", ${ }^{126}$ Freud tenta entender quais as atitudes possíveis para, depois da Primeira Guerra Mundial, os homens conseguirem recuperar aquilo que lhes foi roubado por violências de toda a sorte.

Ela [a guerra] não destruiu apenas a beleza das paisagens que atravessou e as obras de arte que encontrou no seu caminho, ela atingiu também nosso orgulho pelas qualidades de nossa cultura, nosso respeito por tantos poetas e artistas, nossa esperança, enfim, por uma superação das diferenças entre povos e raças. [...] Caso renunciemos a tudo que foi perdido, o próprio luto também enfraquece e então nossa libido torna-se novamente livre, pois ainda somos jovens e cheios de vida para substituir os objetos perdidos por novos objetos possíveis, preciosos ou mais preciosos ainda. Esperemos que em relação às perdas dessa guerra não se

${ }^{124}$ Cecília Meireles. "Epigrama no 1”, Obra poética (Viagem) José Aguilar, 1958, p. 3.

${ }^{125}$ Cecília Meireles. "Ritmo”, Obra poética (Vaga Música) José Aguilar, 1958, p. 139.

${ }^{126}$ Sigmund Freud. "Transitoriedade”, in Arte, Literatura e os Artistas. Trad. Ernani Chaves, Editora Autêntica, Belo Horizonte, 2015.p. 223-224. 
caminhe de maneira diferente. Se antes o luto for superado, isso mostrará que nossa elevada avaliação dos bens culturais não sucumbiu à experiência de sua fragilidade. Reconstruiremos tudo o que a guerra destruiu, talvez com fundamentos mais sólidos e mais duráveis do que antes. $^{127}$

Os nacionalismos posteriores ao fim da Primeira Guerra, a não superação do conflito e a consequente guerra em 1939, mostram que as apostas de Freud não se concretizaram, mas sua resposta nos parece viva nos versos de Cecília. O que se apresenta em "Mar absoluto" é a aposta no definitivo por meio de uma renúncia que possa enfraquecer o luto e libertar o espírito para a construção de novos afetos e realidades. Não é de se estranhar que em Mar absoluto e outros poemas tenhamos poemas de luto coletivo, referentes aos conflitos da Segunda Guerra Mundial, mas tratados de forma individualizada ${ }^{128}$ e um longo e belo poema de luto individual, "Elegia", em que a morte da avó tem a centralidade absoluta dos versos e no espírito do eu-lírico. Diante do luto, mundial e particular, a poesia ocupa um papel fundamental, ela propicia ao homem a não identificação com o transitório e lhe convida para contemplar as regiões elevadas e estáveis.

A escolha de Cecília pelo absoluto parte da premissa de que o ápice de sua busca viria através de uma negatividade total, representada pela diluição do sujeito. A totalidade desse novo mar que se apresenta ao final do poema não é aquela positiva, e de certa forma iluminista, da "Máquina do mundo", rejeitada por Drummond. A verdade trazida pelo absoluto é nascida dos sucessivos projetos que se frustram e recomeçam (assim como a própria onda). A escolha pela forma livre dos versos forja a procura apaixonada que só encontra repouso no suspiro final. Esta negatividade é a maneira ceciliana de superar a morte, o destino e o horror que os homens podem impor ao mundo e uns aos outros, porque a ausência que preenche o absoluto não é a falta que esvazia a vida mas é a substância de tudo, que liberta os homens do fardo de suas individualidades: uma negatividade tão profunda que engole a si mesma e instaura um vazio equivalente ao eterno.

\footnotetext{
127 Idem. ibidem. p. 224.

${ }^{128}$ Como: "Lamento da noiva do soldado", "Balada do soldado Batista", "Lamento do oficial por seu cavalo morto".
} 
Ora, o que a cultura não lhe deu ela trazia em si com força explosiva. E era uma mulher de tão bom senso que nunca deixou de resolver com acerto os seus problemas; de tão bom gosto que ainda hoje eu mesma sou a sua aluna de estética; de tanto sentido prático, que conseguiu desembaraçar-se de todas as confusões em que mergulharam dez anos de mortes consecutivas e dinheiros esparsos, e ainda me legou a sua casa, ao morrer. Para uma mulher ter atravessado tudo isso fiel às suas saudades, absolutamente 
só, em suas aflições, é necessário possuir qualidades muito poderosas, que não se encontram constantemente, e com essa eficácia. ${ }^{129}$

\section{A morte concreta e o amor cotidiano}

\section{1 "Tudo em ti era uma ausência que se demorava"}

Se pensarmos nos poemas já estudados nesse trabalho, veremos que "Elegia" é mais acessível no que concerne a uma compreensão global. Com pouca dificuldade identifica-se o assunto e o tom da poesia: "Elegia" é um poema escrito em razão da morte de Jacinta Benevides, avó de Cecília Meireles. Contudo, essa facilidade comovida com que nos identificamos com as palavras da poeta não incide na leitura crítica e embaraça o aprofundamento do olhar. Isso se dá porque o poema, apesar de tratar de uma experiência muito concreta para todos, é custoso de ser discutido e analisado. O último poema de Mar absoluto e outros poemas pertence ao universo da confissão íntima, e, por vezes, durante a análise, nos pareceu invasivo o exercício de tentar explicá-lo. Afinal, quais palavras os vivos podem dizer aos mortos? Acreditamos que o exercício crítico mais acertado num poema como esse é tentar revelar as particularidades da saudade e do afeto, repetindo a homenagem a esse amor cotidiano que está no silêncio “obrigatório e secreto" de nossas vidas.

Nessa análise, retomamos o tema da morte de familiares que fora elaborado em "Mar absoluto", fechando uma espécie de círculo construído pela falta do outro. Aqueles rostos congelados pelos mares do Norte ou caídos entre corais e pérolas pelos mares do Oriente, aqui assumem sua feição definitiva. Por consequência, o que fora uma ausência abstrata, dos fantasmas que compunham a longínqua multidão passada, assume em "Elegia" a forma de um luto concreto. A abstração e o impulso viageiro serão substituídos pela densidade da matéria e revestidos de uma profunda imobilidade. Nesse poema final, a totalidade fica a cargo da morte e, portanto, não estará ao alcance do eu-lírico, que somente a supõe. A abertura de Mar absoluto e outros poemas acaba confrontada pela experiência concreta da morte: a imaginação, a poesia, o sonho ou a distância não aliviam por completo o sofrimento. A própria estrutura do poema ajuda-nos a entender isso, pois "Elegia" é uma composição de movimentos líricos que constroem uma narrativa de despedida, sua longa extensão (são ao todo oito poemas menores que o compõem) dá a ver a dor e a resistência diante da derradeira partida.

${ }^{129}$ Lição do poema, cartas de Cecília Meireles a Armando Côrtes-Rodrigues. Org e notas, Celestino Sachiet. Ponta Delgada, Instituto Cultural Ponta Delgada, 1998. p. 71. 
Mar absoluto e outros poemas tem em sua abertura um exercício do mover-se parado, e o sujeito lírico ceciliano desenvolve sua maior propensão: a viagem, a sutilização do real e a escolha pela imaginação, possibilitadas por uma grande inserção lírica que disfarça qualquer estímulo exterior que possa ter motivado a expressão da poeta. Nossa análise de "Mar absoluto" tentou mostrar que a experiência da viagem levou o sujeito a ressignificar a perda, a falta, a ausência, de tal forma que essas negatividades adquiram um rosto totalizante e libertador. No entanto, essa escolha prévia pela distância não engloba "Elegia", que, como em "Os dias felizes", não procura pelo mesmo longe de "Irrealidade", mas quer se agarrar ao pequeno do cotidiano, como se assim, pudesse recuperar a presença da avó.

Entendemos que toda a terceira parte de Mar absoluto e outros poemas, composta por "Elegia", deva ser encarada como um único longo poema. Uma vez que nele há, além de unidade temática, uma espécie de progressão do assunto no tempo. O poema fora escrito entre os anos de 1933 e 1937, durante sua leitura sentimos a mudança das estações do ano, o que fica expresso pelo florescimento da natureza, pelo canto das cigarras e pelo começo da temporada de chuvas. O contínuo e circular movimento da natureza revela aos poucos a imobilidade da poeta, que se vê prostrada diante de uma vida que se renova "inutilmente", já que o ser amado é perdido. Em razão da extensão de "Elegia", nos dedicamos a uma análise específica do terceiro e oitavo poemas.

Elegia

1933-1937

À memória de Jacinta Garcia Benevides, minha Avó.

“... le sang de nos ancêtres qui forme avec le nôtre cette chose sans équivalence qui d'ailleurs ne se répétera pas..."

- R. M. Rilke, "Lettres à un jeune poète".

1

Minha primeira lágrima caiu dentro dos teus olhos.

Tive medo de a enxugar: para não saberes que havia caído.

No dia seguinte, estavas imóvel, na tua forma definitiva, modelada pela noite, pelas estrelas, pelas minhas mãos. 
Exalava-se de ti o mesmo frio do orvalho; a mesma claridade da lua.

Vi aquele dia levantar-se inutilmente para as tuas pálpebras, e a voz dos pássaros e a das águas correr,

- sem que a reconhecessem teus ouvidos inertes.

Onde ficou teu outro corpo? Na parede? Nos móveis? No teto?

Inclinei-me sobre o teu rosto, absoluta, como um espelho.

E tristemente te procurava.

Mas também isso foi inútil, como tudo mais.

2

Neste mês, as cigarras cantam

e os trovões caminham por cima da terra, agarrados ao sol.

Neste mês, ao cair da tarde, a chuva corre pelas montanhas, e depois a noite é mais clara,

e o canto dos grilos faz palpitar o cheiro molhado do chão.

Mas tudo é inútil,

porque os teus ouvidos estão como conchas vazias, ${ }^{130}$

e a tua narina imóvel

não recebe mais notícia

do mundo que circula no vento.

Neste mês, sobre as frutas maduras cai o beijo áspero das vespas...

- e o arrulho dos pássaros encrespa a sombra,

como água que borbulha.

Neste mês, abrem-se cravos de perfume profundo e obscuro;

a areia queima, branca e seca,

junto ao mar lampejante:

de cada fronte desce uma lágrima de calor.

Mas tudo é inútil,

porque estás encostada à terra fresca,

e os teus olhos não buscam mais lugares

nesta paisagem luminosa,

e as tuas mãos não se arredondam já

para a colheita nem para a carícia.

Neste mês, começa o ano, de novo, ${ }^{131}$

e eu queria abraçar-te.

Mas é tudo inútil:

${ }^{130}$ Na primeira edição: "porque teus ouvidos estão secos como conchas vazias".

${ }^{131}$ Na primeira edição, o verso "Neste mês, começa o ano, de novo" marca o início de uma nova estrofe. 
eu e tu sabemos que é inútil que o ano comece.

3

Minha tristeza é não poder mostrar-te as nuvens brancas, e as flores novas, como aroma em brasa, com suas coroas crepitantes de abelhas.

Teus olhos sorririam, agradecendo a Deus o céu e a terra: eu sentiria teu coração feliz como um campo onde choveu.

Minha tristeza é não poder acompanhar contigo o desenho das pombas voantes, o destino dos trens pelas montanhas, e o brilho tênue de cada estrela brotando à margem do crepúsculo.

Tomarias o luar nas tuas mãos, fortes e simples como as pedras, e dirias apenas: "Como vem tão clarinho!"

E nesse luar das tuas mãos se banharia a minha vida, sem perturbar sua claridade, mas também sem diminuir minha tristeza.

4

Escuto a chuva batendo nas folhas, pingo a pingo. Mas há um caminho de sol entre as nuvens escuras. $\mathrm{E}$ as cigarras sobre as resinas continuam cantando.

Tu percorrerias o céu com teus olhos nevoentos, e calcularias o sol de amanhã, e a sorte oculta de cada planta.

E amanhã descerias toda coberta de branco, brilharias à luz como o sal e a cânfora, ${ }^{132}$ tomarias na mão os frutos do limoeiro, tão verdes, e entre o veludo da vinha, verias armar-se o cristal dos bagos.

E olharias o sol subindo ao céu com asas de fogo.

Tuas mãos e a terra secariam bruscamente.

Em teu rosto, como no chão, haveria flores vermelhas abertas.

${ }^{132}$ Foi suprimido o verso: "mirarias os cravos, contentes com a chuva noturna,". 
Dentro do teu coração, porém, estavam as fontes frescas, sussurrando.

E os canteiros viam-te passar

como a nuvem mais branca do dia.

\section{5}

Um jardineiro desconhecido se ocupará da simetria desse pequeno mundo em que estás.

Suas mãos vivas caminharão acima das tuas, em descanso, das tuas que calculavam primaveras e outonos,

fechadas em sementes e escondidos na flor!

Tua voz sem corpo estará comandando, entre terra e água,

o aconchego das raízes tenras,

a ordenação das pétalas nascentes.

À margem desta pedra que te cerca, o rosto das flores inclinará sua narrativa:

história dos grandes luares, crescimento e morte dos campos, giros e músicas de pássaros, arabescos de libélulas roxas e verdes.

Conversareis longamente, em vossa linguagem inviolável.

Os anjos de mármore ficarão para sempre ouvindo: que eles também falam em silêncio.

Mas a mim - se te chamar, se chorar - não me ouvirás, por mais perto que venha, ${ }^{133}$ não sou mais que uma sombra caminhando em redor de uma fortaleza.

Queria deixar-te aqui as imagens do mundo que amaste:

o mar com seus peixes e suas barcas;

os pomares com cestos derramados de frutos;

os jardins de malva e trevo, com seus perfumes brancos e vermelhos.

E aquela estrela maior, que a noite levava na mão direita.

E o sorriso de uma alegria que eu não tive, mas te dava.

${ }^{133}$ Na primeira edição, são usados os dois pontos ao invés da vírgula. 
Tudo cabe aqui dentro:

vejo tua casa, tuas quintas de fruta, as mulas deixando descarregarem ceirões repletos, e os cães de nomes antigos ladrando majestosamente para a noite aproximada.

Range a atafona sobre uma cantiga arcaica: e os fusos ainda vão enrolando o fio para a camisa, para a toalha, para o lençol.

Nesse fio vai o campo onde o vento saltou.

Vai o campo onde a noite deixou seu sono orvalhado. Vai o sol com suas vestimentas de ouro cavalgando esse imenso gavião do céu.

Tudo cabe aqui dentro: teu corpo era um espelho pensante do universo. E olhavas para essa imagem, clarividente e comovida.

Foi do barro das flores, o teu rosto terreno, e uns liquens de noite sem luzes se enrolaram em tua cabeça de deusa rústica.

Mas puseram-te numa praia de onde os barcos saíam para perderem-se.

Então, teus braços se abriram, querendo levar-te mais longe: porque eras a que salvava. E ficaste com um pouco de asas.

Teus olhos, porém, mediram a flutuação do caminho. Por isso, tua testa se vincou de alto a baixo, e tuas pálpebras meigas se cobriram de cinza.

7

O Crepúsculo ${ }^{134}$ é este sossego do céu com suas nuvens paralelas e uma última cor penetrando nas árvores até os pássaros.

É esta curva dos pombos, rente aos telhados, este cantar de galos e rolas, muito longe;

e, mais longe, o abrolhar de estrelas brancas,

${ }^{134}$ Na primeira edição “Crepúsculo” está grafado com minúscula. 
ainda sem luz.

Mas não era só isto, o crepúsculo:

faltam os teus dois braços numa janela, sobre flores,

e em tuas mãos o teu rosto,

aprendendo com as nuvens a sorte das transformações.

Faltam teus olhos com ilhas, mares, viagens, povos, tua boca, onde a passagem da vida tinha deixado uma doçura triste, que dispensava palavras.

Ah, falta o silêncio que estava entre nós, e olhava a tarde, também.

Nele vivia o teu amor por mim, ${ }^{135}$ obrigatório e secreto.

Igual à face da Natureza:

evidente, e sem definição.

Tudo em ti era uma ausência que se demorava: uma despedida pronta a cumprir-se.

Sentindo-o, cobria minhas lágrimas com um riso doido.

Agora, tenho medo que não visses

o que havia por detrás dele.

Aqui está meu rosto verdadeiro, defronte do crepúsculo que não alcançaste.

Abre o túmulo, e olha-me:

dize-me qual de nós morreu mais.

Hoje! Hoje de sol e bruma, com este silencioso calor sobre as pedras e folhas!

Hoje! Sem cigarras nem pássaros.

Gravemente. Altamente.

Com flores abafadas pelo caminho, entre essas máscaras de bronze e mármore no eterno rosto da terra.

Hoje.

Quanto tempo passou entre a nossa mútua espera! $\mathrm{Tu}$, paciente e inutilizada,

${ }^{135}$ Na primeira edição: "Nele vivia teu amor por mim", marca o começo de uma nova estrofe. 
cantando ${ }^{136}$ as horas que te desfaziam.

Meus olhos repetindo essas tuas horas heroicas, no brotar e no morrer desta última primavera

que te enfeitou.

Oh, a montanha de terra que agora vão tirando do teu peito! $!^{137}$

Alegra-te, que aqui estou, fiel, neste encontro, como se do modo antigo vivesses ou pudesses, com minha chegada, reviver.

Alegra-te, que já se desprenderam as tábuas que te fecharam, como se desprendeu o corpo em que aprendeste longamente a sofrer.

E, como o áspero ruído da pá cessou neste instante, ouve o amplo e difuso rumor da cidade em que continuo, - tu, que resides no tempo, no tempo unânime!

Ouve-o e relembra não as estampas humanas: mas as cores do céu e da terra. o calor do sol, a aceitação das nuvens, o grato deslizar das águas dóceis, Tudo o que amamos juntas.

Tudo em que me dispersarei como te dispersaste.

E mais esse perfume de eternidade, intocável e secreto, que o giro do universo não perturba.

Apenas, não podemos correr, agora, uma para a outra.

Não sofras, por não te poderes levantar do abismo em que te reclinas: não sofras, também, se um pouco de choro se debruça nos meus olhos, procurando-te.

Não te importes que escute cair, no zinco desta humilde caixa, teu crânio, tuas vértebras, teus ossos todos, um por um...

Pés que caminhavam comigo, mãos que me iam levando,

${ }^{136}$ Na primeira edição: "Contando".

${ }^{137} \mathrm{Na}$ primeira edição, este verso estava isolado, em um monóstico. 
peito do antigo sono,

cabeça do olhar e do sorriso...

Não te importes. Não te importes...

$\mathrm{Na}$ verdade, tu vens como eu te queria inventar:

e de braço dado desceremos por entre pedras e flores.

Posso levar-te ao colo, também,

Pois na verdade estás mais leve que uma criança.

- Tanta terra deixaste porém sobre o meu peito! ${ }^{138}$

irás dizendo, sem queixa,

apenas como recordação.

E eu, como recordação, te direi:

- Pesaria tanto quanto o coração que tiveste,

o coração que herdei?

Ah, mas que palavras podem os vivos dizer aos mortos?

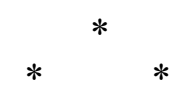

E hoje era teu dia de festa!

Meu presente é buscar-te.

Não para vires comigo:

para te encontrares com os que, antes de mim,

vieste buscar, outrora.

Com menos palavras, apenas.

Com o mesmo número de lágrimas.

Foi lição tua chorar pouco,

para sofrer mais.

Aprendi-a demasiadamente. ${ }^{139}$

Aqui estamos, hoje.

Com este dia grave, de sol velado.

De calor silencioso.

Todas as estátuas ardendo.

As folhas, sem um tremor.

Não tens fala, nem movimento nem corpo.

$\mathrm{E}$ eu te reconheço.

Ah, mas a mim, a mim, quem sabe se me poderás reconhecer!

\footnotetext{
${ }^{138} \mathrm{Na}$ primeira edição, o ponto de exclamação era seguido de vírgula.

${ }^{139} \mathrm{Na}$ primeira edição, este verso estava isolado, em um monóstico.
} 


\subsection{A morte}

O leitor da poesia ceciliana deve estar certo de que a morte dá tom a toda reflexão da poeta sobre o instante. Esse pasmo é tão agudo para Cecília Meireles que já era tema de suas elucubrações na infância:

Mas OLHINHOS DE GATO sentiu como se lhe puxassem o coração para fora do peito. Uma certeza súbita prendeu-a num círculo de sombra. Dentinho de arroz iria também. Iria numa noite dessas, quando ela estivesse dormindo, talvez. Tudo vai... tudo vai. Aperta-se com o dedo a água na pedra, e ela está fugindo, fugindo e continuando seu rumo... Consegue-se prender mansamente na mão um pássaro macio, e ele desliza para seu voo, e só se sente a leveza que deixam, quando já não estão... ${ }^{140}$

Essa "súbita certeza" é escancarada com a morte de Jacinta Benevides em 1931"141, a avó que lhe serviu de família e a quem era tão próxima. Em razão da tristeza, a poeta não consegue a totalidade procurada em "Mar absoluto" ou o distanciamento que pacifica as tensões humanas, como em "Irrealidade". Enredada, a composição do poema acaba por lhe servir de único alívio possível. Por isso, apesar do intervalo de tempo entre a morte da avó e a composição do poema (cerca de dois anos), a intuição do leitor deve apostar que "Elegia" é um poema de luto. Dada sua força afetiva, a perda não será de pronto aceita ou encarada como parte natural do ciclo da vida, nos poemas “1", “2”, “3” e “4”, o sujeito colocará a morte à prova da realidade, buscando no mundo qualquer vestígio do ser amado. O fracasso dessa empreitada muda o ambiente do poema e transporta o sujeito para o cemitério e para a materialidade do corpo morto, deflagrando a dor e uma profunda tristeza.

Em "Elegia", a distinção entre o mundo da vida natural e o da morte se dá pelo movimento da primeira e pela imobilidade da segunda, fora isso, ambos os universos (da vida e da morte) parecem compor um mistério que se encerra em si mesmo e que, portanto, só pode ser compreendido internamente. A morte apresenta-se como: "narina imóvel”, mãos que não se arredondam, olhos que não buscam lugares, uma voz sem corpo que comanda "o aconchego

\footnotetext{
${ }^{140}$ Cecília Meireles. Olhinhos de gato. São Paulo: Editora Moderna, 1981. p.10

141 Como consta no arquivo disponibilizado em: http://www2.assis.unesp.br/arquivocecilia/index3.html. Organizado pela $\operatorname{Prof}^{\mathrm{a}} \mathrm{Dr}^{\mathrm{a}}$ Ana Maria Domingues de Oliveira.
} 
das raízes tenras" e "a ordenação das pétalas nascentes". O esforço da poeta é o de compreender esse mundo que a natureza compartilha com a morte. Em razão da dificuldade: "Mas a mim se te chamar, se chorar - não me ouvirás,/ por mais perto que venha, não sou mais que uma sombra/ caminhando em redor de uma fortaleza.", o poema se estende em nove partes, cujo encontro acaba parcialmente resolvido pela imaginação: "Na verdade, tu vens como eu te queria inventar".

Huizinga, em $O$ outono da Idade Média, explica que as representações artísticas da morte durante a Idade Média seguiam um padrão dividido em três motivos: $o$ questionamento do desaparecimento dos que tiveram glórias no mundo; a visão horripilante do corpo morto em decomposição; e a dança macabra, na qual a morte "arrasta consigo as pessoas de qualquer profissão, de qualquer idade" ${ }^{142}$. Todos os três motivos queriam alertar aos homens sobre a efemeridade da vida e a necessidade de se buscar a eternidade a partir das virtudes cristãs. De alguma forma, Cecília atualizará esses motivos em "Elegia", assumindo agora uma perspectiva bastante individual, ao invés da didática cristã, e cercada de espanto diante da morte de quem se ama. Em razão disso, os motivos, apesar de retomarem a tradição medieval, têm naturezas distintas, a bruteza e até o grotesco das representações medievais revelavam o horror da morte para alertar a importância da vida eterna (alcançada através da conduta cristã). Já as delicadas imagens cecilianas vão caracterizando a morte como uma espécie de "fortaleza" que encerra e também dilui o morto, que passa a ser parte da natureza e de seus mistérios.

As tantas representações dos cadáveres em putrefação em catedrais pela Europa são convites à conversão e, mesmo que terríveis, um conforto para aquele que crê. Na poesia de Cecília, as lindas imagens vão disfarçando o vazio e revelando um enorme desconhecimento sobre o que há (se é que há) depois da morte. Esse entendimento mais comovido e materialista realmente não era algo preocupante para o homem medieval, para o qual a morte era mais próxima e mais natural. De toda forma, apesar das respostas cecilianas para a morte diferirem das medievais, as perguntas permanecem; e logo no poema "1", vemos o motivo que pergunta (ubi sunt?) que irá se desdobrar nas quatro partes seguintes:

[...]

Onde ficou teu outro corpo? Na parede? Nos móveis? No teto?

Inclinei-me sobre teu rosto, absoluta, como um espelho.

E tristemente te procurava.

Mas também isso foi inútil, como tudo mais.

142 Johan Huizinga. Outono da Idade Média. Trad. Francis Petra Jansen. São Paulo, Cosac Naify, 2013. p.222. 
O "outro corpo" ao qual a poeta se refere é o corpo vivo, da presença física que se vê esgotada na morte. Mesmo considerando inútil a procura, a busca continua se repetindo, até que se verifique que o "outro corpo" não está nos lugares que o ser amado ocupava ou que lhe caracterizavam. Ao verificar que a avó já não habita sua antiga casa, representada metonimicamente pelas "paredes", pelos "móveis" e pelo "teto", a poeta se direciona para os ambientes externos, tentando encontrar nos lugares alguma espécie de sobrevida para a avó. Nada surgirá como resposta para a procura, nada resta da avó no mundo, a não ser aquilo que sobrevive na poeta, pela memória ou por determinada forma, herdada, de perceber o mundo. Por isso, quando a poeta encara o corpo morto da avó, no poema "1", só é capaz de ver sua própria imagem refletida: "Inclinei-me sobre o teu rosto, absoluta, como um espelho", sem disso tirar lição alguma.

O segundo motivo apresentado por Huizinga aparece a partir da quinta parte, por meio de imagens do corpo se desfazendo ou do som dos ossos caindo sobre o zinco. Todas essas representações serão discretas e atenuadas, como é comum à poesia de Cecília Meireles. A decomposição será caracterizada como retorno ao natural, e, portanto, entremeada por terra, flores e quaisquer outros elementos naturais:

À margem desta pedra que te cerca, o rosto das flores inclinará sua narrativa: história dos grandes luares, crescimento e morte dos campos, giros e músicas de pássaros, arabescos de libélulas roxas e verdes.

Conversareis longamente em vossa linguagem inviolável.

$[\ldots]$

Tu, paciente e inutilizada, cantando as horas que te desfaziam. $[\ldots]$

E, como o áspero ruído da pá cessou neste instante, $[\ldots]$

Não te importes que escute cair, no zinco desta humilde caixa, teu crânio, tuas vértebras, teus ossos todos, um por um... $[\ldots]$

A imagem do corpo se desfazendo ou o apelo para os próprios ossos soltos na urna são, apesar de sempre atenuados, de uma materialidade impactante e não tão raro aparecem na 
poesia de Cecília Meireles. A inglesinha de "Naufrágio antigo", a mãe que clama pela volta do filho de "Lamento da mãe órfã", ambos já citados, ou ainda o cavalo de "O cavalo morto" são exemplos de descrições de corpos apodrecidos, "metade gente, metade universo", que podem se mover ou pensar inseridos na própria natureza, encerrados em seu próprio mistério.

A “dança macabra” é talvez o motivo mais transfigurado dentre todos que apresentamos. Há no final do poema a ideia do encontro do morto com os demais mortos, o que, como Huizinga explica, também configurava a representação de tal dança, já que inicialmente não havia uma figura alegórica da morte que viesse buscar o recente morto, mas eram os mortos anteriores a ele que se encarregavam dessa tarefa. Entretanto, em "Elegia", é a poeta que reunirá a avó morta aos mortos mais antigos.

E hoje era teu dia de festa!

Meu presente é buscar-te.

Não para vires comigo:

para te encontrares com os que, antes de mim,

vieste buscar, outrora.

Com menos palavras, apenas.

Com o mesmo número de lágrimas.

$[\ldots]$

Como se mostrou impossível trazer o ser amado da morte, Cecília oferece o poema como caminho para que Jacinta também possa encontrar a multidão passada que ela buscara durante a vida, “com menos palavras, apenas". É como se no momento final, a poeta reconhecesse o intransponível da morte e finalmente se despedisse, permitindo, apesar da dor, que a avó passe a compor a multidão de todos aqueles que passaram pela vida.

\subsection{A escolha do gênero elegíaco}

O gênero elegíaco conservou, na literatura clássica, uma forma imutável: o dístico elegíaco, composto por um hexâmetro e um pentâmetro, seu conteúdo, entretanto, variava. A noção de elegia enquanto poema necessariamente de lamentação só se estabelece posteriormente. Mesmo diante da variedade de conteúdos, o repertório elegíaco nunca excluiu o tema da morte e do lamento. A origem do gênero é incerta e provoca grande debate entre os críticos $^{143}$, mas seu vínculo com os cantos mortuários sempre é retomado nessas discussões.

\footnotetext{
${ }^{143}$ Para uma primeira introdução sobre o tema e as dificuldades críticas de classificar a elegia grega ler a introdução da dissertação de Rafael Brunhara, A elegia grega, ocasião de performance e tradição épica: o caso de Tirteu. Disponível em: file://C:/Users/Administrador/Downloads/2012_RafaelDeCarvalhoMatielloBrunhara_VCorr\%20(1).pdf
} 
De qualquer maneira, para a literatura moderna, desde o século XVI, o que permanece é a noção de lamento e de poesia reflexiva, sem qualquer necessidade de um metro, forma específica ou mesmo de uma nomeação direta. A elegia se tornou para nós uma espécie de tom que anima o poema, desta maneira, uma ode, um soneto decassílabo ou uma quadra popular podem ser elegíacos. The new Princeton encyclopedia of poetry and poetics considera que o século XX foi "distinctly elegiac age", por mais que seus poetas já não entendam o gênero dentro de sua convenção, eles ainda o utilizam "to achieve what comfort they can"144.

Muito da poesia de Cecília é composta por esse sentimento elegíaco, principalmente no que se refere à postura meditativa e lamentosa que busca conforto nos ritmos, nas imagens de delicadeza ou na própria reflexão que motivou o canto. Todavia, em sua poesia completa, somente sete poemas ${ }^{145}$, excluindo "Elegia", de Mar absoluto e outros poemas, a poeta nomeou de elegia, são eles: “A elegia do fantasma" ${ }^{146}$, de Nunca mais... e Poemas dos poemas (1923); "Elegia"147, de Vaga Música; "Elegia a uma pequena borboleta"148, de Retrato Natural; "Elegia sobre a morte de Gandhi”(1948) ${ }^{149}$; “Elegia dos boêmios"(1956) $)^{150 ;}$;"Elegia” (1959) $)^{151}$ e “Elegia”(1959) $)^{152}$, de Dispersos. Fora os títulos, os poemas têm em comum o lamento fúnebre, muitas vezes tendo como pano de fundo o clássico tema do ubi sunt. Desta maneira, o gênero elegíaco na poesia ceciliana reúne a postura reflexiva e contemplativa, comum às elegias modernas, e o tema da morte e da brevidade da vida, presentes nos poetas antigos, principalmente em Mimnermo.

No poema que analisaremos neste ensaio não será diferente, veremos a postura meditativa encontrar-se com o lamento fúnebre, de tal forma que além da despedida, a poeta repensa o mundo a partir da perda. A pungente pergunta do verso: “Ah, mas que palavras podem os vivos dizer aos mortos?" ressoa com vigor na tradição elegíaca moderna e faz lembrar a "Primeira elegia", de Rilke:

Quem, se eu gritasse, entre as legiões de Anjos me ouviria? E mesmo que um deles me tomasse inesperadamente em seu coração, aniquilar-me-ia

\footnotetext{
${ }^{144}$ The new Princeton encyclopedia of poetry and poetics. Princeton University Press, 1993. p. 324.

${ }^{145}$ Em oposição ao largo número de epigramas, gênero que também tem sua origem ligada ao universo fúnebre.

${ }^{146}$ Cecília Meireles. Poesia Completa vol.I. Org. Antonio Carlos Secchin. Nova Fronteira, Rio de Janeiro, 2001.p.44.

${ }^{147}$ Idem. Ibidem. p.410.

${ }^{148}$ Idem. Ibidem. p.608.

${ }^{149}$ Cecília Meireles. Poesia Completa vol.II. Org. Antonio Carlos Secchin. Nova Fronteira, Rio de Janeiro, 2001.p.1608.

${ }^{150}$ Idem. Ibidem. p. 1753.

${ }^{151}$ Idem. Ibidem. p. 1800.

${ }^{152}$ Idem. Ibidem. p. 1804.
} 
sua existência demasiado forte. [...] ${ }^{153}$

O tom de lamentação, de resposta fadada à impossibilidade são bastante semelhantes, e os poemas gravitam em torno dessas questões. Rilke não suportando ouvir a voz de Deus, Cecília dilacerada pela morte do ser amado; ambos reafirmando a solidão, a angústia e a crença de que os vivos precisam dos mortos. Por outras razões, mas com a mesma força, tal verso também faz pensar em Catulo $101^{154}$. Poema em que a persona poética constata a inutilidade de falar à muda cinza, e assim como Cecília, faz de seu poema a própria cerimônia de despedida.

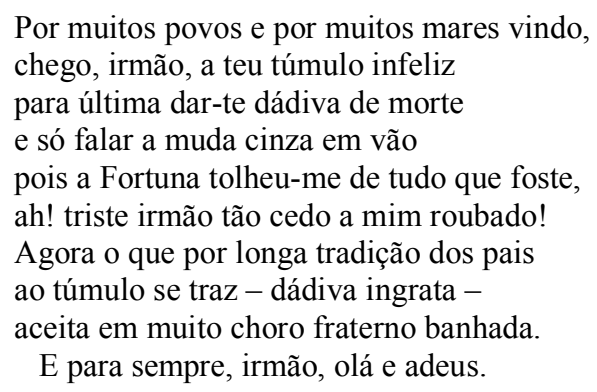

Cecília Meireles mistura a postura reflexiva e de lamento com o tema da morte, compondo um poema que ao mesmo tempo homenageia o morto, tenta encontrar consolo para dor, refletindo sobre a ideia de descendência.

\section{4 "Faltam teus olhos como ilhas, mares, viagens..."}

3

Minha tristeza é não poder mostrar-te as nuvens brancas, e as flores novas, como aroma em brasa, com suas coroas crepitantes de abelhas.

Teus olhos sorririam, agradecendo a Deus o céu e a terra: eu sentiria teu coração feliz como um campo onde choveu.

Minha tristeza é não poder acompanhar contigo o desenho das pombas voantes, o destino dos trens pelas montanhas, e o brilho tênue de cada estrela brotando à margem do crepúsculo.

Tomarias o luar nas tuas mãos,

\footnotetext{
${ }^{153}$ Rainer Maria Rilke. Elegias de Duíno. Trad. e comentários Dora Ferreira da Silva. 6 a edição. Biblioteca Azul, São Paulo, 2013. p. 11.

${ }^{154}$ Catulo. O Livro de Catulo. Trad. João Angelo Oliva Neto. São Paulo, Edusp, 1996, p. 154.
} 
fortes e simples como as pedras,

e dirias apenas: "Como vem tão clarinho!"

E nesse luar das tuas mãos se banharia a minha vida,

sem perturbar sua claridade,

mas também sem diminuir a minha tristeza.

No poema "2", a poeta capta os movimentos da natureza que caracterizam o verão (a chuva, a noite clara, o canto das cigarras, as frutas maduras e etc.) e considera que "tudo é inútil”. Há uma espécie de mágoa em relação à vida exuberante que se mostra aos sentidos, de tal modo que as descrições das belezas naturais ("a chuva corre pelas montanhas", "o arrulho dos pássaros", "abrem-se cravos de perfume profundo" etc.) funcionam quase como uma mácula à qual a poeta responde insistentemente: "Mas é tudo inútill”. No poema “3”, essa revolta ganha o aspecto da tristeza, do não poder estar contigo, e a natureza, já menos exuberante, vai ratificar a saudade e mostrar o caráter do que fora perdido. Veremos aqui que a poeta se dedicará a relembrar e reconstruir os modos da avó em relação à natureza, mais especificamente, a uma natureza domesticada, comum aos jardins e aos quintais. Daquele lugar do qual podemos ver, sem medo, as frutas amadurecendo para serem comidas, as flores desabrochando e toda a sorte de delicadezas naturais. Numa natureza sem feras famintas ou plantas venenosas.

Como se trata de um poema que nasce amparado na memória, há nele o encontro de duas temporalidades: a do passado, na presença da avó, quando a poeta apontava o mundo e a do agora, em que estática, Cecília observa o fim do dia. Além desse encontro de tempos, há ainda o tempo de duração do próprio poema, que se inicia durante a tarde com suas nuvens brancas, passa pelos pássaros procurando repouso e pelas primeiras estrelas nascendo no poente, para terminar com o luar. O clima crepuscular chama atenção para uma delicada tristeza que vai se ampliando pela saudade. Apesar da aproximação entre o crepúsculo e a tristeza da poeta, a natureza não se afeta com a vida íntima de Cecília, mas, de um modo bastante duro, se oferece tal qual era durante a vida da avó, ressaltando ainda mais a falta e também uma separação entre o que o sujeito sente e a vida exterior.

Para dar vazão à saudade, a poeta lança mão do futuro do pretérito ("sorririam”, "sentiria", "banharia"), reconstruindo o que a vida havia sido na presença do ser amado e enumerando o que fora para sempre perdido. E por mais que esse seja um poema cheio de seres e cenários, ele é marcado pelo vazio, retomado a cada repetição do sintagma "minha tristeza é não poder". Tal sintagma funciona como uma espécie de mote que submete todo o visto, enumerado na primeira e terceira estrofes, a uma acentuada falta de significado. Existe no poema “3” uma dinâmica entre a natureza e a relação de neta e avó, os apontamentos de Cecília 
reafirmam uma forma de convivência entre elas, que pode ser iluminada pelas lembranças descritas em Olhinhos de gato. As reações aos movimentos da natureza vão construindo um retrato íntimo dessas duas mulheres e as particularidades do afeto que tinham uma pela outra.

Na narrativa de memórias, a avó, Boquinha Doce, insurge como uma figura conhecedora de uma natureza cíclica e eterna e guardadora das narrativas que atribuem sentido à vida, sempre compreendendo os seres e as plantas, profundamente.

Conforme a lua, deitam-se galinhas, e num dia previsto e infalível, nascem pintos que Boquinha Doce ajuda a retirar das cascas, formas úmidas e moles, enroladas em si mesmas, e que ela facilmente desenrola e anima, falando num sorriso: "Vamos nascer que já é hora!" E eles dizem que sim, com um claro biquinho novo, cor de milho tenro $[\ldots]^{155}$.

Ah! Boquinha Doce iria, então, ficar velha também, assim? Não. Boquinha Doce contalhe muitas estórias prodigiosas. [... $]^{156}$

Então, a menina sentia brisa e sol por dentro de si. Saltava pelas pedras, abraçava-se às árvores. Tudo renascera! Tudo renascia! Boquinha doce, de mãos postas, parava no alto da sacada, olhando. A menina considerava-a de longe, com pensamentos indeterminados, mas que exprimiam esta emoção: "Ela é imortal!"157

A vida, quando tocada pela avó, se ordenava de uma forma idílica, tudo era chamado a despertar. A habilidade com o mundo natural parece também ligada à capacidade de contar "estórias prodigiosas" que inserem a avó numa espécie de núcleo de verdade, lhe garantindo eternidade. Pelos olhos da neta, Jacinta tinha tamanho manejo da vida que a entendia por dentro, fazendo parte de uma espécie de núcleo de uma grande narrativa. Em razão disso, na falta da avó, a poeta busca os lugares nos quais Jacinta sempre esteve inserida, de forma tão totalizante. A representação da natureza como um lugar de paz, beleza e educação para grandes assuntos da vida é muito presente na poesia e na prosa de Cecília Meireles, em Mar absoluto e outros poemas será muito retomada na série de "Os dias felizes", como em: "Noite", "Madrugada", "Visita da chuva", entre outros. Além de ser amplamente trabalhada no livro de memórias através das imagens do quintal e dos pequenos seres que o habitam.

Como esse é um poema dialógico, por mais que seja solitário, as supostas respostas de Jacinta aos acenos da neta configuram aquilo que falta à cena depois da morte da avó. Ao que nos parece, o "mostrar" da poeta só vê sentido no sorriso que a avó abriria, "agradecendo a Deus o céu e a terra". É como se a poeta não fosse capaz de sozinha construir o sentido que vai do céu a terra, dessa maneira, o transbordamento do sorriso da avó traria também para sua vida

${ }^{155}$ Cecília Meireles. Olhinhos de gato. São Paulo: Editora Moderna, 1981. p.22.

${ }^{156}$ Idem. Ibidem. p. 16.

${ }^{157}$ Idem. Ibidem. p.30. 
a felicidade e a calma de "um campo onde choveu". Estruturalmente, percebemos que o poema se divide em estrofes que descrevem uma ação impedida, na primeira e na terceira, ("é não poder mostrar-te"; "é não poder acompanhar contigo") e naquelas que imaginam respostas para essa falta (com verbos no futuro do pretérito), a segunda, a quarta e a quinta. Existe nessa alternância um interessante jogo entre mobilidade e imobilidade, que vai, no decorrer do poema, retratando a forma específica como cada uma delas interage com o movimento da vida.

Logo na primeira estrofe, notamos o movimento do olhar da poeta do alto ("as nuvens brancas") ao baixo (“as flores novas”). Há aqui um encantamento quanto ao que se vê, que incide sobre o substrato sonoro do poema pela repetição da consoante plosiva e a vogal aberta ("brancas" "brasas", "abelhas"), que forçam o leitor à pronúncia mais lenta e aberta, dando uma impressão de espanto diante da beleza da natureza. Entretanto, apesar da beleza, o olhar passa pelas imagens sem se fixar a nenhuma delas, de tal maneira que cada imagem encerra-se em um único verso. Essa postura da percepção pode estar amparada na natureza daquilo que é visto, tanto nessa primeira estrofe quanto na terceira, todos os objetos de seleção da poeta indicam mobilidade: as nuvens, as abelhas sobre as flores, as pombas se recolhendo para o sono, os trens que cortam as montanhas e as estrelas brotando no crepúsculo. Talvez inspirada pelo fluir que a natureza sugere, a poeta opte por não reter as imagens descritas. Mas, devido à própria seleção de objetos, esse procedimento também descreve uma espécie de imaginação voltada ao movimento, algo semelhante ao que Bachelard entenderá sobre o imaginário do ar.

Nesse estudo dos tipos de imaginação, cabem ao ar as representações da mobilidade, de tal forma que uma representação ideal desse tipo de imaginário necessitaria de um fluxo contínuo de imagens, dando a sensação de uma espécie de "imaginação sem imagens". ${ }^{158}$ Essa mobilidade é comum à poesia de Cecília Meireles e deixa-nos uma sensação de suave elevação do espírito e de aparente uniformidade, que se dá em razão do próprio movimento constante. Tão definitiva é essa postura poética que muitas vezes a mobilidade é mais expressiva do que as próprias imagens que vão sendo retratadas. Esse ritmo impõe a fluidez à concretude do cotidiano, restando ao leitor a tão falada impressão de uma poesia apartada da vida concreta e distante do mundo. Ao colocar-se no fluxo contínuo de uma imaginação dinâmica, a poeta não só se aparta do cotidiano como também não se fixa em estados de ânimo, como ela bem ensinou em "Motivo": "Não sou alegre nem sou triste:/ sou poeta.// Irmão das coisas fugidias,/ não sinto gozo nem tormento./ Atravesso noite e dia/ no vento."

${ }^{158}$ Gaston Bachelard. O ar e os sonhos. Trad. Antonio de Pádua Danesi. São Paulo: Martins Fontes, 1990.p. 2. 
Em "Elegia", vemos que essa mobilidade está comprometida pelo luto que não permite que a imaginação alce seu voo em direção à conformação de um sentido, como o fora em "Irrealidade" e em "Mar absoluto". Por conta disso, na primeira e na terceira estrofes do poema “3”, as imagens de fluidez estão atravessadas pelo motivo da tristeza de tal maneira que cada verso mobiliza, através da imagem que descreve, mais uma faceta da falta e da imobilidade, afinal a tristeza restringe a ação e a imaginação da poeta. Os versos dessas estrofes são predominantemente nominais, tendo como núcleo da ação o verbo "ser". A escolha pelos infinitivos e gerúndios ("não poder mostrar-te"; "brotando") inclinam, novamente, nossa sensibilidade mais à imagem do que à ação, que no poema "3" está severamente comprometida. Essas estrofes encerram em si uma tensão, sempre aliviada na estrofe seguinte, quando a avó, renascida pela lembrança da poeta, organiza a falta que encenava na cena descrita anteriormente.

Nessas estrofes em que a memória resgata a presença da avó, teremos um maior uso verbal (“sorririam”, “sentiria”, “choveu”, “Tomarias", “dirias”, "se banharia”). A dinamicidade da vida que se oferecia era recebida por Jacinta com alegria, a avó de Cecília ao agradecer "a Deus o céu e a terra", oferece uma unidade pacificadora para o fluxo constante de imagens que se reorganizam em seu coração, que é como "um campo onde choveu". O silêncio e a tranquilidade de um campo onde choveu destoam das imagens construídas na primeira estrofe. As abelhas e as nuvens talvez dessem maior abertura ao sonho e à fantasia, mas não garantem a estabilidade tranquilizadora de "um campo onde choveu". Já a chuva traz consigo uma ideia de reunião do céu e da terra por meio da água, além de fazer alusão à vida e à fertilidade que essas águas trazem para a terra.

Como a cena é referente ao depois da ação, o campo, e, portanto o coração, já se encontra agradecido e feliz pela unidade alcançada.

\footnotetext{
Teus olhos sorririam, agradecendo a Deus o céu e a terra: eu sentiria teu coração feliz como um campo onde choveu.
}

Nessa segunda estrofe, a avó tem pouquíssimo movimento, mesmo seu sorriso é demonstrado pelo olhar. Centrada e quieta, ela se opõe à atitude da neta que apontava e mostrava a vida exterior. Mas, apesar da tranquilidade, são suas reações que atribuem significado ao visto; a partir delas, o lépido movimento do apontar ganhará densidade de sentido. Mais especificamente, ele vai caracterizando o eu-lírico pela falta e a avó pelo 
preenchimento. Jacinta, assim como fora nas narrativas da infância, parece filtrar o mundo por um viés ordenador, talvez motivado pela fé, como sugere o quinto verso do poema, que era capaz de desacelerar ou mesmo frear o movimento incessante da vida e indicar novas possibilidades para a sensibilidade. Do que a neta, aparentemente, não era capaz.

\begin{abstract}
Eu tenho conhecido muita gente: do mundo inteiro, de todas as idades, religiões, níveis de cultura e educação Sempre penso que minha Avó era uma raridade. Se ela tivesse vivido noutro ambiente, com outros recursos ao seu alcance, quem sabe eu seria apenas a sombra do que ela deixou de ser? [...] Quando minha vida fica muito triste, sonho logo com minha Avó. Sonho com sua casa, volto a encontrá-la, e tudo é tão nítido que mesmo em sonho lhe digo: "E eu pensei que V. tinha morrido! Felizmente, não é verdade". E depois acordo. Tenho muita pena de não ter feito por ela muitas coisas que na verdade não pude fazer. Sempre me acho mesquinha, insuficiente, débil. Mas também ela não precisava de mim para nada. Ela vivia num outro plano, que sempre pensei que Deus fosse seu amigo pessoal, parente nosso, cujo endereço ela conhecia e frequentava. ${ }^{159}$
\end{abstract}

O trecho da carta não pode ser lido fora do âmbito do afeto, por isso, ele mais revela o que ficou impresso na poeta do que descreve algo de preciso sobre a avó. E se o retrato não interessa tanto a um possível biógrafo, ele é muito significativo para quem deseja entender "Elegia". Nele vemos que Jacinta parecia dotada de um conhecimento sobre o destino da criação. É esperado portanto que seu coração não se mova com a fluência que o mundo oferece, mas que se fixe na certeza de um segredo que a tranquiliza em meio à fluidez de tudo. Essa mulher, que era como uma sacerdotisa para a neta, não precisava de nada, mas podia oferecer o alento para o pasmo ceciliano diante da morte. Em razão disso, em "Elegia", a poeta enxerga uma fratura que não pode ser superada (“Abre o túmulo, e olha-me:/dize-me qual de nós morreu mais").

A lembrança da avó, do "campo onde choveu", direciona o olhar da poeta para o alto, à altura do horizonte. Apesar de não estar se movendo do alto ao baixo, como na primeira estrofe, o olhar da poeta retoma as imagens dinâmicas (o voo, o trem, o crepúsculo). A primeira delas é "o desenho das pombas voantes" seguida pelo "destino dos trens pelas montanhas", ambas trazem em comum a ideia da linha e de um sentido do mover-se. O movimento das pombas assim como o dos trens pelas montanhas obedece a algum sentido linear, do percurso que realizam e do destino que obedecem. O percurso ("desenho") e o "destino" podem se entrelaçar através da ideia de sentido, seja material ou espiritual. Ao que nos parece, apesar de discreta, existe aqui uma inflexão, pois a lembrança da avó mobiliza a busca de um novo sentido que parece tentar se construir pela ideia do percurso e da linha. E talvez aqui caiba retomar a bela

${ }^{159}$ Lição do poema, cartas de Cecília Meireles a Armando Côrtes-Rodrigues. Org. e notas, Celestino Sachiet. Ponta Delgada, Instituto Cultural Ponta Delgada, 1998.p. 71. 
epígrafe de Rilke, que abre "Elegia", retirada da carta de 26 de dezembro de 1908, na qual, o poeta tenta explicar a importância da solidão a Kappus. Para tanto, acaba se valendo da influência secreta que nossos antepassados têm em nossa vida:

Em tudo o que o senhor tiver que viver e fazer, ela [a solidão] agirá como uma influência anônima, assim como o sangue de nossos antepassados se movimenta em nós, misturandose ao nosso e formando com ele a única coisa única e irreparável que somos em cada curva de nossa vida. ${ }^{160}$

A poeta procura pelas linhas, com seus sentidos e percurso, para talvez entender onde nela repousa essa "coisa única e irreparável”, uma bússola que lhe dê o sentido que Jacinta por tantas vezes soube encontrar, nas muitas experiências com a morte de tantos entes queridos. Ao final do poema "6", a poeta desenvolve o que aqui é só uma indicação, e descreve essa trajetória triste, coberta de perdas, vivenciada pela avó:

Mas puseram-te numa praia de onde os barcos saíam para perderem-se.

Então, teus braços se abriram, querendo levar-te mais longe: porque eras a que salvava.

E ficaste com um pouco de asas.

Teus olhos, porém, mediram a flutuação do caminho.

Por isso, tua testa se vincou de alto a baixo,

e tuas pálpebras meigas

se cobriram de cinza.

De tanto ver os barcos "perderem-se", Jacinta acaba por abrir os braços querendo arremessar-se mais longe, mais ao alto, porque ela havia ficado "com um pouco de asas", mas teus sábios olhos souberam medir a incerteza do caminho e sua testa "se vincou de alto a baixo". A pequena narração é bastante simbólica, mas não deixa de nos causar sugestões muito precisas que referenciam a história de vida de Jacinta em relação à perda dos netos, da filha, do genro e do marido. O que nos leva a pensar que o envelhecimento (a testa vincada) chegou para Jacinta como uma espécie de resistência, um não entregar-se à morte, que a fez abrir mão das asas e fincar-se em terra firme, com o peso das cinzas sobre seus olhos. É essa firmeza que Cecília busca durante o poema “ 3 ”, primeiro através da natureza que ambas amavam e a qual Jacinta parecia tão intimamente inserida e segundo, dada a impassibilidade da natureza diante da tristeza, na memória.

${ }^{160}$ Rainer Maria Rilke, Cartas a um jovem poeta. Trad. Paulo Rónai. 24a ed. Editora Globo, São Paulo, 1996. p. 75 . 
Como não reconhece em si a força que via na avó, sua imaginação dinâmica quebra com as imagens de linearidade, provavelmente por não alcançar o sentido que procurava, e salpica junto com as estrelas que nascem depois do pôr-do-sol ("e o brilho tênue de cada estrela/ brotando à margem do crepúsculo"). O espalhamento da linha em pontos, novamente, só retornará para uma ideia de unidade através da avó.

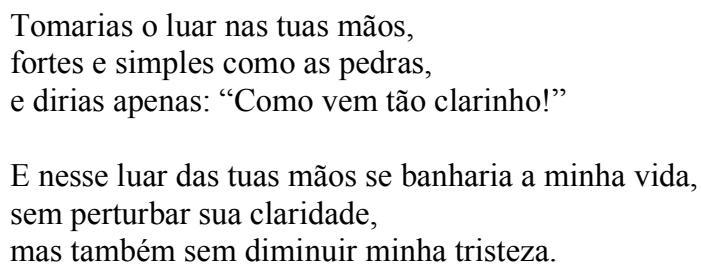

A avó é responsável por trazer o sentido que se perde, e como recolhesse a luminosidade esparsa das estrelas, cria uma unidade e a traz para perto da neta. Assim como fizera viver os pintinhos, Jacinta faz o parto da lua: "Como vem tão clarinho", e ilumina o final do poema "3". O uso do diminutivo não só incide numa atitude afetuosa como também prolonga a fala da avó, o que se intensifica pelo uso de advérbio "tão", de tal maneira que o tempo da leitura sugere o movimento das mãos que vão buscar o luar. Por isso, no verso posterior, o luar já está assentado junto de Jacinta. Há no "luar das tuas mãos" um movimento de equalização de dois planos opostos (alto e baixo), uma vez que a lua não está refletida em suas mãos, e sim o luar é emitido por elas, pois a preposição "de" ("luar das tuas mãos") carrega consigo esse significado de pertencimento. Essa aproximação de céu e terra é marca definitiva das ações da avó no poema, primeiro através da totalidade de Deus (que agrega o céu e a terra), na quinta estrofe; depois por meio da imagem do "campo onde choveu"; e por fim, na descida da lua ao chão.

É complexa a cena construída nessa última estrofe, as mãos de Jacintas são como pedras ("fortes e simples") e trazem o luar em si, onde Cecília pode banhar sua vida. A escolha lexical ("luar", "banhar" e "pedras") sugere ao leitor uma espécie de lago, criado a partir da lua e suportado pelas mãos da avó. O quadro é de acolhimento, contudo de uma proteção que não satisfaz o sujeito, afinal, a saudade persiste e a claridade da lua não é capaz de diminuir a tristeza. Toda a exuberância da imagem final, mais uma vez, não coincide com o estado de ânimo da poeta.

O poema vinha se amparando na memória para recriar as cenas de convívio e as reações da avó diante da natureza, na estratégia de aliviamento da dor. Assim podemos entendê-lo até a penúltima estrofe, já que na última a imaginação afasta a poeta dos elementos concretos (da tarde e do pôr-do-sol) e a faz criar essa espécie de lago, feito da lua e das mãos da avó. Contudo, 
a transfiguração do real, que fora tão proveitosa para o encontro com o outro em "Irrealidade", não é capaz de apaziguar o luto e a fantástica imagem final só faz iluminar a tristeza e a solidão magoada da poeta, que insatisfeita com a imaginação, vai buscar o cemitério e procurar pela concretude da morte.

\subsection{Ouve-me!}

8

Hoje! Hoje de sol e bruma,

com este silencioso calor sobre as pedras e as folhas!

Hoje! Sem cigarras nem pássaros.

Gravemente. Altamente.

Com flores abafadas pelo caminho,

entre essas máscaras de bronze e mármore

no eterno rosto da terra.

Hoje.

Quanto tempo passou entre a nossa mútua espera!

$\mathrm{Tu}$, paciente e inutilizada, cantando as horas que te desfaziam.

Meus olhos repetindo essas tuas horas heroicas, no brotar e morrer desta última primavera

que te enfeitou.

Oh, a montanha de terra que agora vão tirando do teu peito!

Alegra-te, que aqui estou,

fiel, neste encontro,

como se do modo antigo vivesses

ou pudesses, com a minha chegada, reviver.

Alegra-te, que já se desprenderam as tábuas que te fecharam, como se desprendeu o corpo

em que aprendeste longamente a sofrer.

E, como o áspero ruído da pá cessou neste instante, ouve o amplo e difuso rumor da cidade em que continuo,

- tu, que resides no tempo, no tempo unânime!

Ouve-o e relembra

não as estampas humanas: mas as cores do céu e da terra.

o calor do sol,

a aceitação das nuvens,

o grato deslizar das águas dóceis,

Tudo o que amamos juntas.

Tudo em que me dispersarei como te dispersaste.

E mais esse perfume de eternidade,

intocável e secreto,

que o giro do universo não perturba.

Apenas, não podemos correr, agora, uma para a outra. 
Não sofras, por não te poderes levantar

do abismo em que te reclinas:

não sofras, também,

se um pouco de choro se debruça nos meus olhos,

procurando-te.

Não te importes que escute cair, no zinco desta humilde caixa, teu crânio, tuas vértebras,

teus ossos todos, um por um...

Pés que caminhavam comigo, mãos que me iam levando,

peito do antigo sono,

cabeça do olhar e do sorriso...

Não te importes. Não te importes...

$\mathrm{Na}$ verdade, tu vens como eu te queria inventar:

e de braço dado desceremos por entre pedras e flores.

Posso levar-te ao colo, também,

Pois na verdade estás mais leve que uma criança.

- Tanta terra deixaste porém sobre o meu peito! irás dizendo, sem queixa,

apenas como recordação.

E eu, como recordação, te direi:

- Pesaria tanto quanto o coração que tiveste,

o coração que herdei?

Ah, mas que palavras podem os vivos dizer aos mortos?

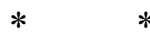

E hoje era o teu dia de festa!

Meu presente é buscar-te.

Não para vires comigo:

para te encontrares com os que, antes de mim,

vieste buscar, outrora.

Com menos palavras, apenas.

Com o mesmo número de lágrimas.

Foi lição tua chorar pouco,

para sofrer mais.

Aprendi-a demasiadamente.

Aqui estamos, hoje.

Com este dia grave, de sol velado.

De calor silencioso.

Todas as estátuas ardendo.

As folhas, sem um tremor.

Não tens fala, nem movimento nem corpo.

E eu te reconheço.

Ah, mas a mim, a mim, 
quem sabe se me poderás reconhecer!

Como a natureza não supre a falta da avó, a poeta desloca-se para o cemitério e lá, no poema " 6 ", reconhece o mundo que lhe pertencera: "Tudo cabe aqui dentro:\vejo tua casa, tuas quintas de fruta". Ao leitor fica impreciso afirmar se esse dentro é aquele da intimidade da poeta ou o do caixão e do túmulo que encerram tudo o que Jacinta foi e amou no mundo. Ainda no poema " 6 ", retorna a ideia da avó como conhecedora e parte integrante da vida natural. De tal maneira que, ao fiar, vai construindo o vento, a noite, o sol.

\footnotetext{
Range a atafona sobre uma cantiga arcaica: e os fusos ainda vão enrolando o fio para a camisa, para a toalha, para o lençol.

Nesse fio vai o campo onde o vento saltou. Vai o campo onde a noite deixou seu sono orvalhado.

Vai o sol com suas vestimentas de ouro cavalgando esse imenso gavião do céu.
}

$\mathrm{O}$ ato de tecer ou fiar é, no plano do trabalho, um paradigma dos afazeres femininos. $\mathrm{Na}$ literatura, Penélope tece incessantemente a espera de Ulisses e as Moiras fiam as vidas humanas. Nos dois casos, essas mulheres, através da atividade que realizam, controlam seu próprio destino ou o dos demais. Penélope costura para proteger-se de um novo casamento, na fé do regresso do marido e as Moiras determinam os nascimentos, a fortuna e a morte de cada homem. A tecelagem, talvez como a vida humana, se dá num fazer contínuo, através do acúmulo dos fios (dos dias, dos anos), fazendo ver a natureza do desenho, o destino da composição. É com a leveza de quem sabe a forma por detrás do esboço que Jacinta fia o mundo a sua volta, da "camisa" ao "céu".

Além da aproximação entre o tecer e o destino humano, podemos também pensar na relação entre esse ofício e a arte narrativa. Benjamin diferencia os narradores em dois grupos, não necessariamente inconciliáveis, os viajantes e os sedentários. Esses últimos têm como representantes os artífices, que durante o trabalho compartilhavam histórias particulares ou vindas de longe, trazidas por migrantes e por eles recolhidas e assimiladas: "Quando o ritmo do trabalho se apodera dele, ele escuta as histórias de tal maneira que adquire espontaneamente o dom de narrá-las. Assim se teceu a rede em que está guardado o dom narrativo." ${ }^{161}$ Como já

\footnotetext{
${ }^{161}$ Walter Benjamin. "O narrador. Considerações sobre a obra de Nikolai Leskov" in Magia e técnica, arte e politica.
} 
comentamos, a habilidade narrativa de Jacinta é um dos seus mais importantes atributos, uma vez que suas histórias e, até mesmo, seus gestos vão atribuindo sentido e unidade ao mundo:

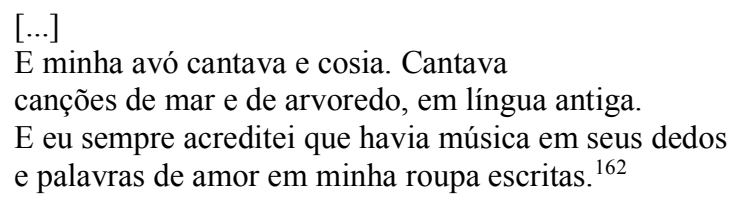

Em "Desenho", o ritmo do trabalho manual concentra o corpo, mas libera o espírito, bem ao modo dos narradores de Benjamin. Nesse poema predominam verbos no pretérito imperfeito (tempo por excelência da narração) e seu assunto tem um cunho memorialista, que narra o início da vida da poeta. A canção em "língua antiga" cose junto com a agulha e linha um sentido narrativo do amor; cuja síntese é apresentada ao final do poema, quando a poeta é capaz de formular aquilo que permanece do vivido e configura a experiência compartilhada.

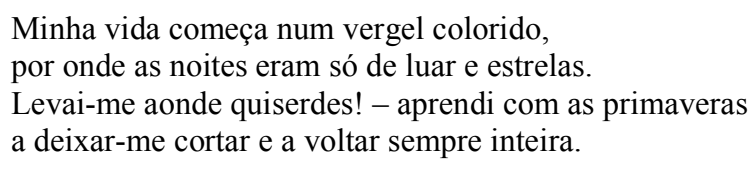

Também "Elegia" é um poema narrativo, da narração do luto, da dor, do amor. Mas não só. É principalmente da procura inteligente de um sentido, como é próprio de Cecília Meireles em Mar absoluto e outros poemas. O sentido encontrado em "Desenho" é, sem dúvida, promissor, assim como o fora o de "Mar absoluto", desenhando uma abertura do sujeito que faz da falta uma possibilidade de totalidade ("deixar-me cortar e a voltar sempre inteira"). Em "Elegia", talvez a poeta não alcance a abertura desses últimos, pelo menos não de forma isolada, uma vez que a concretude da experiência da perda não libera a imaginação para a reformulação (ou transfiguração) do real.

Presa a tal circunstância, não bastará o reconhecimento desse novo lugar onde "tudo cabe aqui dentro", descoberto no poema " 6 ". Em razão disso, logo no poema posterior, o sujeito voltará a lamentar a falta: "Faltam teus olhos com ilhas, mares, viagens, povos"; acabando por reconhecer que a morte da avó fora também a sua.

Aqui está meu rosto verdadeiro, defronte do crepúsculo que não alcançaste.

Abre o túmulo, e olha-me:

dize-me qual de nós morreu mais.

162 Cecília Meireles. Obra poética. (Mar absoluto e outros poemas) Rio de Janeiro, José Aguilar, 1958.. p. 382383 
No poema "8", apesar de intensa tristeza, haverá uma atenuação do impedimento que o sujeito sente, e essa abertura possibilita o encontro de despedida. Ainda é calor, como a poeta mostrou no poema "2", contudo aqui a sensação do calor esvazia o espaço de seres animados ("Sem cigarras nem pássaros") e vai corroborando para o tom de gravidade da despedida. O eulírico continua no cemitério, como estivera desde o poema " 5 ", e será nele o adeus final. "Elegia", mesmo não fazendo muitas referências diretas à passagem do tempo, pretende criar uma relação temporal entre a morte da avó e o "hoje", do poema "8". Essa contagem do tempo é ilustrada pelo título e também pelas mudanças da natureza ocorridas durante o seguir de todo o poema. Encontramos duas importantes referências temporais em "Elegia", a primeira, no poema "2" ("eu e tu sabemos que é inútil que o ano comece"), acompanhada de descrições que dão a ver o verão no Brasil, como já comentamos. A segunda está no poema " 8 ": "no brotar e morrer desta última primavera/ que te enfeitou.". Nesse verso a poeta faz uso do pronome demonstrativo para indicar proximidade, de tal modo que nos faz pensar que a temporalidade da morte está ligada à primavera e a do canto ao verão, o interim dessas duas estações ilustra a "mútua espera" do poema.

Contudo, o período entre uma primavera e um verão não corresponde à data (19331937) presente no título, cuja finalidade, como nos parece, é informar ao leitor o tempo gasto na composição do poema. O contraste entre o tempo de duração do poema e da sua composição é muito significativo para "Elegia", pois ilustra um sentimento arrastado que não corresponde ao tempo dos calendários, dependendo exclusivamente do sujeito.

\begin{abstract}
O luto profundo, a reação à perda de uma pessoa amada contém o mesmo estado de ânimo doloroso, a perda de interesse pelo mundo externo - na medida em que este não faz lembrar o morto -, a perda da capacidade de escolher um novo objeto de amor - em substituição ao pranteado - e o afastamento de toda e qualquer atividade que não tiver relação com a memória do morto. Facilmente compreendemos que essa inibição e esse estreitamento do ego são a expressão de uma dedicação exclusiva ao luto, na qual nada mais resta para outros propósitos e interesses. 163
\end{abstract}

Como o luto aparta o sujeito do mundo, sua relação com a temporalidade também se afeta, já que as atividades a que se dedica estão ligadas ao passado, a vida antes da perda. Em razão disso, o que acompanhamos no poema é, antes do que uma sucessão temporal empírica, a duração do luto. Quando chegamos ao poema "8", o sujeito já repetiu as atividades caras ao morto amado, tendo procurado por ele em sua casa, na natureza e tentado, em alguma medida,

${ }^{163}$ Sigmund Freud. Luto e melancolia. Trad. e Introd. Marilene Carone. Cosac Naify, São Paulo, 2011. p. 47. 
reproduzir seus modos; apesar de todos os esforços terem se mostrado inúteis diante do real. Depois de tanto esforço e de muito ter experimentado a falta, o sujeito decide se despedir e libertar-se do exercício de dedicação exclusiva ao luto. A reiteração do "hoje" nas três primeiras estrofes do poema " 8 " e nas duas primeiras da segunda parte, separada graficamente por asteriscos, demonstra uma espécie de decisão em findar esse longo processo de lamento e rememoração.

O dia de "sol e bruma", apesar da luminosidade, sugere algo da ordem do mistério e nesse espaço pouco límpido, a poeta caminha entre os túmulos (“máscaras de bronze e mármore"), procurando pelo lugar em que a avó fora enterrada. É inevitável não nos lembrarmos da multidão passada de "Mar absoluto", aqui posicionada em seus lugares concretos, mais uma vez compondo o caminho da poeta em direção a um possível absoluto. A procura, até o momento do encontro do túmulo, dá-se nas três primeiras estrofes do poema. A avó, "paciente e inutilizada", passara o tempo de espera "cantando as horas" que desfaziam seu corpo, totalmente imersa na lógica da natureza. A expressão, na primeira edição do poema, era "contando as horas" e, portanto mais ansiosa e angustiada. Em 1958, a própria poeta altera o verso e suaviza a espera de Jacinta, que absolutamente inserida na natureza "canta" a passagem do tempo. O desespero da espera fica todo a cargo da poeta, que ligada às saudades, mantevese presa às lembranças ("Meus olhos repetindo essas tuas horas heroicas”).

Ao se encontrarem, no último verso da quarta estrofe, inicia-se o processo de desenterrar a avó para que aconteça a despedida: "Oh, a montanha de terra que agora vão tirando do teu peito". É importante a escolha de um sujeito plural para essa ação, pois como vimos em Outono da Idade Média, fora responsabilidade dos mortos antepassados trazer o morto recente para os terrenos do além vida. Já comentamos que, em "Elegia”, a “dança macabra” virá no sentido de fazer uma ponte entre Jacinta e sua multidão passada ("Meu presente é buscar-te./ Não para vires comigo:/ para te encontrares com os que, antes de mim,/ vieste buscar, outrora.”). Além disso, parece-nos que esses mortos antigos são também os responsáveis por desenterrar a morta e por abrir a esquife em que estava contido o corpo, trazendo a avó para se despedir da neta. A “dança macabra", em "Elegia", não aponta para outro plano, para um transcendente. A morte é tratada como mistério e a única ação possível é, além da despedida, a entrega do morto amado aos antepassados.

Quando é cessado o processo de retirar Jacinta de seu túmulo (“E, como o áspero ruído da pá cessou neste instante"), na sétima estrofe, a poeta pede que sua avó ouça o "amplo e difuso rumor da cidade em que continuo". O pedido, apesar da referência à cidade, é voltado 
para o mundo que ambas amaram juntas e ao qual a poeta recorreu durantes todas as partes de "Elegia: "as cores do céu e da terra./ o calor do sol,/ a aceitação das nuvens,/ o grato deslizar das águas dóceis". À avó, agora residente no "tempo unânime", é apontado aquele mundo que já não mais a continha, mas que ela amara. A retomada dessa exterioridade funciona no poema como reafirmação de um compromisso ("Tudo o que amamos juntas./ Tudo em que me dispersarei como te dispersaste.”) e de descendência.

Depois da aproximação da avó e de retomado o mundo que ambas amaram, a poeta passará a consolar a morta da distância que as separam; “Apenas, não podemos correr, agora,/ uma para a outra":

Não sofras, por não te poderes levantar do abismo em que te reclinas:

não sofras, também,

se um pouco de choro se debruça nos meus olhos, procurando-te.

$[\ldots]$

Pés que caminhavam comigo, mãos que me iam levando, peito do antigo sono, cabeça do olhar e do sorriso...

A tristeza do poema " 3 " estava em não poder estar contigo na fruição do mundo, como já comentamos. Aqui a poeta fará o exercício pelo lado da avó, a acalmando das dores que lhe sobraram desde a separação. Os sofrimentos da avó estariam ligados ao campo semântico da morte e da imobilidade, como: "Não sofras, por não te poderes levantar" e "Não te importes que escute cair/ [...] teu crânio, tuas vértebras,”. Mesmo quando retomada pela memória, Jacinta não é uma figura de muita mobilidade, contudo seus poucos gestos são dotados de uma serenidade que reconhece um sentido da vida. A morte, em seu caso, transforma o pouco movimento em imobilidade e a noção de sentido em "abismo". A imagem do "abismo em que te reclinas" não é só belíssima como também é precisa para figurar o mistério e a inacessibilidade da morte. O sentido de unidade que Jacinta trazia à vida não desaparece com a morte, mas se fecha em si mesmo, compartilhando, em uma "linguagem inviolável", com a natureza o segredo da vida.

Esse consolo dá vazão a versos muito emotivos que refletem a saudades e retomam o lugar de companheira e também de condutora que Jacinta ocupava na vida da neta: "Pés que caminhavam comigo,/ mãos que me iam levando". A emotividade desse lamento final é seguida 
da última formulação de consolo do poema, "Não te importes. Não te importes...”, e marca a liberação da imaginação para a transfiguração do real:

$\mathrm{Na}$ verdade, tu vens como eu te queria inventar:

e de braço dado desceremos por entre pedras e flores.

Posso levar-te ao colo, também,

Pois na verdade estás mais leve que uma criança.

- Tanta terra deixaste porém sobre o meu peito!

irás dizendo, sem queixa,

apenas como recordação.

E eu, como recordação, te direi:

- Pesaria tanto quanto o coração que tiveste,

o coração que herdei?

Ah, mas que palavras podem os vivos dizer aos mortos?

A liberação da imaginação para a construção de um sentido vai possibilitar o diálogo final, em que a poeta enterra novamente a avó e firma uma espécie de acordo. A fala de Jacinta reclama um direito à vida e uma resistência à morte ("Tanta terra deixaste porém sobre o meu peito!"'), como que cobrando a neta da aceitação de sua partida. Contudo, a poeta, a despeito do pedido, decide findar o luto através de um pacto de troca: a terra pelo coração ("Pesaria tanto quanto o coração que tiveste,/ o coração que herdei?"). Se o coração pode simbolizar o que somos no mais individual, a troca representa um apagamento da poeta que garante a Jacinta uma nova vida, agora através da neta. A morte da avó fora para o eu-lírico um total despedaçamento, que, como vimos no poema “3”, impossibilitou o sujeito de restaurar qualquer unidade de sentido. $\mathrm{O}$ ato, portanto, de herdar o coração figura numa sobrevivência não só da memória da avó, como também da própria poeta. Novamente, é da mais profunda falta que Cecília Meireles encontra meios de ressignificar sua trajetória diante dos fenômenos que lhe tomem a inteligência e/ou o coração.

Contudo, a poeta reconhece que esse último esforço é uma homenagem feita ao vazio, afinal "que palavras podem os vivos dizer aos mortos?". De toda a maneira, fundem-se os destinos e a despedida finalmente acontece:

E hoje era o teu dia de festa!

Meu presente é buscar-te.

Não para vires comigo:

para te encontrares com os que, antes de mim,

vieste buscar, outrora.

Com menos palavras, apenas.

Com o mesmo número de lágrimas.

Foi lição tua chorar pouco, 
para sofrer mais.

Aprendi-a demasiadamente.

Aqui estamos, hoje.

Com este dia grave, de sol velado.

De calor silencioso.

Todas as estátuas ardendo.

As folhas, sem um tremor.

Não tens fala, nem movimento nem corpo.

E eu te reconheço.

Ah, mas a mim, a mim,

quem sabe se me poderás reconhecer!

Os asteriscos que dividem o poema "8" em duas partes marcam uma ruptura em relação ao diálogo anterior, uma vez que, aqui, a poeta parece novamente solitária. O presente final, como já comentamos, é a entrega de Jacinta a seus mortos, o que ocorre por meio da realização do poema. Essa atitude última da poeta representa a aceitação da falta e da morte, e mais do que isso, a certeza da herança adquirida. O legado de "o coração que tiveste", pacto para por fim ao luto, é explicitado: "Foi lição tua chorar pouco,/ para sofrer mais". Tal contenção intensifica o poder do sentimento, que sem expressão externa, concentra-se todo no sujeito. Encarar a continência como modo de intensificar o sentir, não descreve somente a conduta de avó e neta, mas ilumina um dos procedimentos mais evidentes da lírica ceciliana. A poesia de Cecília Meireles é exata (já disse Bandeira) e contida para poder ser amplamente dotada de um sentimento vivo da condição humana.

O ambiente, nessa segunda parte, é ainda quente e o silêncio tão profundo que sequer as folhas tremem. Nesse lugar tão grave, a poeta é capaz de reconhecer a avó, apesar dela não ter fala, "nem movimento nem corpo.". Acreditamos que esse reconhecimento vem de dentro, o pacto de troca fez viver o coração de Jacinta, e sua ausência vive por meio da poeta. Contudo, a presença construída pela memória, pelos hábitos, pelo afeto, por tudo que configura essa herança, não é capaz de superar o oculto e a inacessibilidade da morte, e, portanto, não há troca ou encontro possível. "Elegia" não consegue driblar a totalidade da morte e mesmo que o luto ceda ao tempo e às provas do real, o sujeito sabe do impossível abraço, do tão distante sorriso.

\subsection{A falta e o absoluto}

É curiosa a circularidade que aproxima "Mar absoluto" de "Elegia". A falta neles é o assunto sobre o qual a inteligência lírica se debruça, sem refugiar-se em ritmos ou métrica 
regular. E diferente do que vimos nas obras anteriores, a falta é encarada como problema em Mar absoluto e outros poemas. O sujeito, ao reconhecer uma ausência impositiva vinda do exterior (o apelo das "multidões passadas" ou a morte de Jacinta), procura entendê-la, como se sondasse as possibilidades da construção de um destino que justificasse sua vida e seu modo de ser. Entretanto, por se tratar de uma poeta tão familiarizada à falta, como tentamos mostrar na apresentação desse trabalho, a pesquisa lírica assume o sentido de um aprofundamento intenso, uma vez que ao olhar para essa falta fundante, vê-se o âmago mais profundo do eu. Em razão disso, a procura iniciada com a afirmação: "Foi desde sempre o mar", só poderia, ao final do poema, retornar e enxergar o absoluto, "ah! do Mar Absoluto". Ou ainda, a superação do luto só poderia vir mediante o coração herdado, que passara a viver no interior da poeta. Tudo isso porque a falta vem de dentro, e por mais que o exterior a corrobore, como em "Irrealidade" ou nos poemas de guerra, seu núcleo pertence ao eu-lírico e paradoxalmente é o seu lugar no mundo.

O livro encerra, é o que acreditamos, uma narrativa da falta, cuja justificativa advém do passado pessoal. Como que atando as pontas de sua história, a poeta constrói a narração de sua grande família de navegantes e nela assume as obrigações de dar continuidade à viagem e a uma vida intermeada por ausências. O que é formulado também no poema "Cata, cata, que é viagem da Índia... ${ }^{164 ”, ~ e s c r i t o ~ e m ~ 1961, ~ e m ~ q u e ~ a ~ a v o ́ ~ a s s u m e ~ d i r e t a m e n t e ~ a ~ f a l a ~ e ~ r e a f i r m a ~ o ~}$ missão para Cecília:

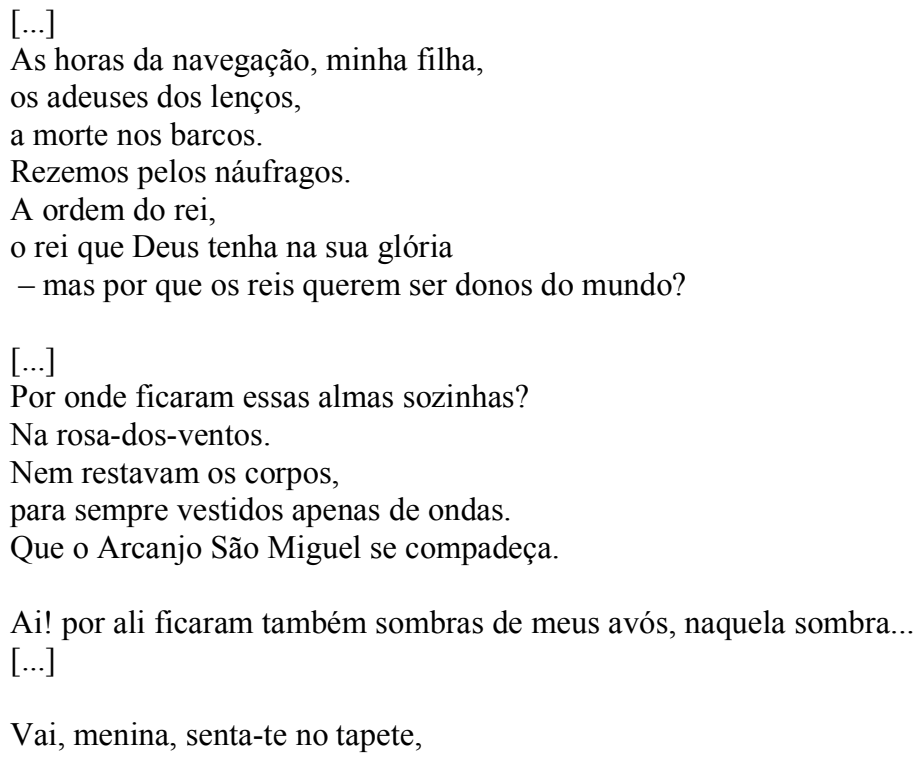

${ }^{164}$ Cecília Meireles. Poesia Completa vol.II. Org. Antonio Carlos Secchin. In Dispersos. Nova Fronteira, Rio de Janeiro, 2001, p. 1876. A poeta também comenta a expressão “Cata, cata que é viagem para Índia”, em entrevista publicada pela revista Manchete, já citada nesse trabalho. 
onde os rubis e as safiras e os diamantes

estão pintados, onde há caminhos para Golconda.

$[\ldots]$

Vamos atrás dos antepassados,

cantando-lhes nossa estranha sorte,

divididos entre a manhã e a noite,

sonhando horizontes,

cercados de ausências,

entre mapas e portulanos, e aromas e vozes náuticas.

$[\ldots]$

O tema da falta é retratado, a priori, como um destino de Jacinta, mas o final do poema assume a voz coletiva ("Vamos atrás dos antepassados"), e atribui para Cecília o mesmo fardo de "ausências". Ambas estão ligadas ao chamado das "vozes náuticas", a procura dos antepassados. Todo esse sentimento irmana "Elegia" e "Mar absoluto". Contudo, a viagem de "Mar absoluto" mostrou ao sujeito que a missão vinda do passado era somente o estímulo primeiro. Uma voz mais ampla impunha-lhe sempre nova rota, a constatação das metamorfoses infinitas do mar a fez entender que na perspectiva do eterno ciclo da vida, a navegação humana não é mais que espuma das ondas.

A leitura do último poema de Mar absoluto e outros poemas remete-nos diretamente ao primeiro, constituindo uma narrativa da falta/ausência ceciliana que supera a questão dos antepassados e configura, apesar de derivada da morte, um comprometimento com a vida:

Ao contrário do puro nada, ela não apenas supõe o ser, como também o exige, clama e reclama por ele, aprofundando em nós os sentimentos de nostalgia, de saudades, de tristeza, verdadeiros apelos existenciais dirigidos à presença do ser ausente. ${ }^{165}$

Mar absoluto e outros poemas exige de seu leitor uma presença, uma busca de sentido: essa é a navegação idealizada. E mesmo tendo no fechamento um poema de lamento como "Elegia”, seu horizonte é um "Mar absoluto". Esses dois poemas retomam-se um ao outro, num movimento de constatação e transfiguração da falta para algo mais amplo do que a família e que inclui a trajetória de toda vida humana. Não à toa esse livro fora publicado em 1945, quando o fim da catástrofe, que fora a Segunda Guerra Mundial, mostrou-nos uma profunda destruição do espírito humano; revelando a impotência da cultura diante da barbárie.

Da constatação insuportável e irreparável da perda, não só dos entes queridos, mas de toda vida inocente, Cecília Meireles trilha e nos lega um caminho ético em Mar absoluto e

\footnotetext{
${ }^{165}$ Alfredo Bosi. “Cecília Meireles: a música ausente”. Suplemento Literário, Diário de São Paulo em 20/02/1965. p.4.
} 
outros poemas. A falta, como explica Bosi, exige o ser e, portanto, estimula em nós uma nova forma de estar no mundo, em que, junto de nossos mortos, aprendemos a unidade da vida e da cultura humana, que, apesar dos desastres, nunca se despedaçaria por completo. Nesse sentido, quando a poeta pede, em "Elegia", que sua avó ouça o mundo e o relembre, é dessa eternidade que trata. A lição de Jacinta não é só a do sofrer, mas a de amar o mundo em todas as suas delicadezas, esse mundo que sobrevive às "estampas humanas" e representa uma modalidade do eterno. Esse sentimento de eternidade protege-nos do mundo humano perene para nele podermos voltar de uma forma renovada, porque voltamos com a compreensão de que apesar de tudo ser falta, é a partir dela que podemos nos encontrar e vislumbrar algum tipo de unidade e solidez. 


\section{Referências bibliográficas}

\section{De Cecília Meireles}

1945.

MEIRELES, Cecília. Mar absoluto e outros poemas. Porto Alegre, Livraria do globo, . Obra Completa. Rio de Janeiro, José Aguilar, 1958.

. Antologia poética. $2^{\mathrm{a}}$ ed. Rio de Janeiro, Editora do Autor, 1963.

. Obra Completa. Rio de Janeiro, Nova Aguilar, 1977.

. O que se diz o que se entende. Nova Fronteira, São Paulo, 1980.

. Cecília e Mário. Rio de Janeiro, Nova Fronteira, 1996.

. Crônica em Geral. Apresentação e planejamento editorial de Leodegário A. de Azevedo filho. Rio de Janeiro, Nova Fronteira, 1998.

. Crônica de viagem volume 1. Apresentação e planejamento editorial de Leodegário A. de Azevedo filho. Rio de Janeiro, Nova Fronteira, 1998.

Lição do poema, cartas de Cecília Meireles a Armando Côrtes-Rodrigues. Org. e notas, Celestino Sachiet. Ponta Delgada, Instituto Cultural Ponta Delgada, 1998.

. Crônica de viagem volume 2 e 3. Apresentação e planejamento editorial de Leodegário A. de Azevedo filho. Rio de Janeiro, Nova Fronteira, 1999.

filho. São Paulo, Editora Global, 2016.

. Crônicas de Viagem. Vol. 1 ao 3. Organização Leodegário A. de Azevedo . Poesia Completa. Rio de Janeiro: Nova Fronteira, 2001.

. Antologia Poética. São Paulo: Global, 2013

. Batuque, Samba e Macumba. São Paulo: Martins Fontes, 2003.

. Olhinhos de gato. São Paulo: Editora Moderna, 1981.

. Crônicas de educação, volumes 1 a 5. Rio de Janeiro: Nova Fronteira, 2001.

. Escolha seu sonho. Rio de Janeiro: Desiderata, 2007.

. Ilusões do mundo. São Paulo: Global, 2013

. Janela mágica. São Paulo: Moderna, $3^{\text {aed., }} 2003$. 
. Entrevista feita por Pedro Bloch e publicada na revista "Manchete", Ed. n 630, em 16\05\1964. Disponível em: http://www.jornalopcao.com.br/posts/opcao-cultural/aultima-entrevista-de-cecilia-meireles

\section{Específica}

AFFONSO, Ruy. "Cecília Meireles, amiga”. Suplemento Literário, Diário de São Paulo em 20/02/1965.p.2.

ALMEIDA, Lucia Machado de. "Esse instante emprestado". Suplemento Literário, Diário de São Paulo em 20/02/1965. p. 2.

ARRIGUCCI JR., Davi. "Nota sobre Cecília”. O guardador de segredos. São Paulo: Companhia das Letras, 2010.

ANDRADE, Mário. "Viagem" e "Cecília e a poesia". O empalhador de passarinho. São Paulo: Martins, 1972. 2009.

BANDEIRA, Manuel. Apresentação da Poesia Brasileira. São Paulo: Cosac Naify, . "Rebanho de cantigas" e "Sorriso suspenso". Andorinha, andorinha. Rio de Janeiro: José Olympio, 1996.

P. 194.

. "Improviso", in Estrela da vida inteira. Nova Fronteira, Rio de Janeiro, 2009.

BOSI, Alfredo. "Cecília Meireles”. História Concisa da Literatura Brasileira. São Paulo: Cultrix, 1970.

"História de um encontro" e "A poesia da viajante". Entre a Literatura e a História. São Paulo: Editora 34, 2013.

$34,2010$.

“Em torno na poesia de Cecília Meireles”. Céu, Inferno. São Paulo: Editora

Paulo em 20/02/1965. p.4.

CANDIDO, Antonio e CASTELO, e José Aderaldo. "Cecília Meireles", in Presença da literatura brasileira: história e crítica. Editora Bertrand Brasil, 1997. 10ed.

CARPEAUX, Otto Maria. "Cecília Meireles". Pequena Bibliografia Crítica da Literatura Brasileira. Rio de Janeiro: MEC, 1995.

“Poesia Intemporal”. Livros na Mesa. Rio Janeiro: São José, 1960. 
DAMASCENO, Darcy. "Poesia do sensível e do imaginário". In MEIRELES, Cecília. Obra Completa. Rio de Janeiro: Aguilar, 1958.

Cecilia Meireles: O Mundo Contemplado. Rio de Janeiro: Orfeu, 1967. Cecília Meireles: Poesia. Rio de Janeiro: Agir, 1974.

DRUMMOND, Carlos. "Imagens para sempre" Correio da manhã, Rio de Janeiro, 11 de novembro de 1964, p.4.

GARBUGLIO, José. “Cecília Meireles: o transitório e o eterno”. Suplemento Literário, Diário de São Paulo em 20/02/1965. p.1.

GUINSBURG, J. “Cecília Meireles”. Suplemento Literário, Diário de São Paulo em 20/02/1965. p.1.

GOUVÊA, Leila V. B. Cecília em Portugal. São Paulo: Iluminuras, 2001. EDUSP, 2008. Pensamento e "Lirismo Puro" na poesia de Cecília Meireles. São Paulo: (Org.) Ensaios sobre Cecília Meireles. São Paulo: Humanitas-FAPESP, 2007.

GOUVEIA, Margarida Maia. Cecília Meireles: uma poética do eterno instante. Editora Imprensa Nacional-Casa da Moeda, 2002.

HANSEN, João Adolfo. "A vida reinventada". in Mar absoluto e outros poemas. São Paulo: Global, 2015.

LAMEGO, Valéria. A Farpa na Lira: Cecília Meireles na revolução de 30. Rio de Janeiro: Record, 1996.

http://www1.folha.uol.com.br/fsp/1996/8/04/mais!/10.html

LÔBO, Yolanda. Cecília Meireles. Pernambuco, Editora Massangana, 2010.

MELLO, Ana Maria de. UTÉZA, Francis. Oriente e Ocidente na poesia de Cecília Meireles. Porto Alegre, Libertos, 2006.

MOURA, Murilo Marcondes de. O mundo sitiado: a poesia brasileira e a Segunda Guerra Mundial. São Paulo, Editora 34, 2016.

OLIVEIRA, Ana Maria Domingues de. Estudo Crítico da Bibliografia sobre Cecília Meireles. São Paulo: Humanitas, 2001.

RÓNAI, Paulo. "Lembrança de Cecília Meireles"; "Gravado na pedra"; "O Romanceiro da Inconfidência vinte anos depois”. Pois é. Rio de Janeiro: José Olympio, 2014. 
Janeiro: MEC/INL, 1958.

"O Conceito de Beleza em Mar Absoluto" Encontros com o Brasil. Rio de

SADLIER, Darlene J. Imaginary and Theme in the Poetry of Cecília Meireles: a study of Mar Absoluto. Maryland: Studia Humanitatis, 1983.

SANCHES, Miguel.“ Cecília e o tempo inteiriço”. In MEIRELES, Cecília. Poesia Completa (edição do centenário). Rio de Janeiro: Nova Fronteira, 2001.

SCHUARTZ, Miriam Silvia. O avesso do poema: Cecília Meireles e a metamorfose. São Paulo, Grupo Editorial Scortecci, 2012.

SENA, Jorge de. "Cecília Meireles ou os puros espíritos". Suplemento Literário, Diário de São Paulo em 20/02/1965. p.4.

VILLAÇA, Alcides. "Sobre Cecília em Portugal”. In GOUVÊA, Leila. Cecília em Portugal. São Paulo: Iluminuras, 2001.

ZAGURY, Eliane. Cecília Meireles. Petrópolis: Vozes, 1973.

Arquivo Cecília Meireles. Disponível em:

http://www2.assis.unesp.br/arquivocecilia/index3.html

\section{Geral}

ADORNO, T. W. Notas de Literatura I. Trad. Jorge de Almeida. São Paulo: Duas Cidades, 2012.

ADRADOS, Francisco A. Líricos Griecos: elegíacos y yambógrafos arcaicos. Vol.1. Madrid: Consejo Superior de investigaciones científicas, 2007.

AGAMBEN, Giorgio. Infância e História: destruição da experiência e origem da história. Trad. Henrique Burigo. Belo Horizonte: Editora UFMG, 2005.

Teoria estética. Trad. Arthur Mourão. Coimbra: Edições 70, 2008.

AGUILAR, Nelson. Vieira da Silva no Brasil. Museu de Arte de São Paulo, 2007.

ALI, Manuel Said. Versificação em Língua Portuguesa. São Paulo: EDUSP, 2006.

ARENDT, Hannah. A condição humana. Trad. Roberto Raposo. $11^{\mathrm{a}} \mathrm{ed}$. Editora Forense Universitária, 2013.

ARRIGUCCI JR., Davi. Humildade, paixão e morte: a poesia de Manuel Bandeira. São Paulo: Companhia das Letras, 2004.

ARISTÓTELES. Poética. Trad. Eudoro de Sousa. Porto Alegre, Globo, 1966.

AUERBACH, Erich. Mimeses. São Paulo: Perspectiva, 2013. 
BACHELARD, Gaston. A poética do espaço. Trad. Antonio de Pádua Danesi. São Paulo: Martins Fontes, 2012.

Fontes, 1998.

. A água e os sonhos. Trad. Antonio de Pádua Danesi. São Paulo: Martins

Fontes, 1990.

. O ar e os sonhos. Trad. Antonio de Pádua Danesi. São Paulo: Martins

BENJAMIN, Walter. Magia e técnica, arte e política. Trad. S. P. Rouanet. São Paulo: Brasiliense, 1985.

"Destino e caráter" in Escritos sobre mito e linguagem. Org. Jeanne Marie Gagnebin. Trad. Susana Kampff Lages e Ernani Chaves. São Paulo, Editora 34, 2013.

Obras escolhidas III: Um lírico no auge do capitalismo. Trad. José C.

M. de Barbosa e Hemerson A. Batista. São Paulo: Brasiliense, 1994.

BOSI, Alfredo. História concisa da literatura brasileira. São Paulo: Cultrix, 2006.

O ser e o tempo na poesia. São Paulo: Companhia das Letras, 2010.

Literatura e resistência. São Paulo: Companhia das Letras, 2002.

Céu, inferno. São Paulo: Duas Cidades, 2003.

BOWRA, Cecil Maurice. "Early Elegiac and Lyiric Poetry", in Ancient Greek Literature. London: Oxford University Press, 1967. P. 17-31.

BUNHARA, Rafael. A elegia grega, ocasião de performance e tradição épica: o caso de Tirteu. Dissertação (Mestrado em Letras Clássicas), Faculdade de Filosofia, Letras e Ciências Humanas, São Paulo, 2012. Disponível em:

file://C:/Users/Administrador/Downloads/2012 RafaelDeCarvalhoMatielloBrunhara_VCorr $\underline{\% 20(1) . p d f}$

CAMPBELL, Joseph.. The Masks of God-Oriental Mythology. Nova York, The Viking Press, 1962.

CANDIDO, Antonio. Formação da literatura brasileira: momentos decisivos. Rio de Janeiro: Ouro sobre azul, 2011.

Literatura e sociedade. São Paulo: Companhia Editora Nacional, 1970.

O estudo analítico do poema. São Paulo: Humanitas, 2006.

A educação pela noite \& outros ensaios. São Paulo: Ática, 1987.

CATULO. O Livro de Catulo. Trad. João Angelo Oliva Neto. São Paulo, Edusp, 1996. 
CHEVALIER, Jean e GHEERBRANT, Alain. Dicionário de símbolos. Mitos, sonhos, costumes, gestos, formas, figuras, cores, números. Rio de Janeiro, José Olympio, 1994.

COLLOT, Michel. O sujeito lírico fora de si. Trad. Zênia de Faria e Patrícia Sousa Silva Cesaro. Signótica, v. 25, n. 1, p. 221-241, jan./jun. 2013. 1962.

CROCE, Benedetto. Estética. Trad. Angél V. y Goldini. Buenos Aires, Nueva Visión, A poesia. Trad. Flávio L. Chaves. Porto Alegre: UFRS, 1967.

CURTIUS, Ernst Robert. Literatura europeia e Idade média latina. Trad. Paulo Rónai e Teodoro Cabral. São Paulo: EDUSP, 1996.

ELIADE, Mircea. Imagens e Símbolos. Ensaios sobre o simbolismo mágico-religiosa. Trad. Sonia Cristina Tamer. Editora Martins Fontes, São Paulo, 1996.

Mito do Eterno Retorno. Trad. José Antonio Ceschin. Editora Mercuryo, São Paulo, 1992.

ELIOT, T. S. De poesia e poetas. (tradução e prólogo Ivan Junqueira). São Paulo: Brasiliense, 1991. Lisboa: $\overline{\text { Cotovia, } 1992 .}$

Ensaios escolhidos. (Seleção, tradução e notas de Maria Adelaide Ramos)

FALCO, Vittorio de. Os elegíacos gregos. São Paulo: Brusco \& Cia, 1941.

FREUD, Sigmund. Arte, Literatura e os Artistas. Trad. Ernani Chaves, Editora Autêntica, Belo Horizonte, 2015. . Luto e Melancolia. Trad. Marilene Carone. São Paulo, Cosac Naify, 2011.

FRIEDRICH, H. Estrutura da lírica moderna. $2^{\mathrm{a}}$ ed. Trad. Marise M. Curioni e Dora Ferreira da Silva. São Paulo, Duas Cidades, 1991.

HANSEN, João Adolfo. Alegoria. Construção e Interpretação da Metáfora. São Paulo/Campinas: Hedra/Editora Unicamp, 2006.

HEGEL, G. W. F. Curso de estética: poesia. Trad. Marco Aurélio Werle. São Paulo: EDUSP, 2004.

HUIZINGA, Johan . Outono da Idade Média. Trad. Francis Petra Jansen. São Paulo, Cosac Naify, 2013.

JESI, Furio. Literatura y mito. Trad. Antonio Pigrau Rodrígues. Editora Barral, 1972.

KAISER, W. Análise e interpretação da obra literária. Trad. Paulo Quintela. Coimbra: Armênio Amado, 1970, 2 volumes. 
LAFETÁ, João Luiz. Figuração da intimidade: imagens na poesia de Mário de Andrade. São Paulo: Martins Fontes, 1986.

LAPA, M. Rodrigues. Estilística da Língua Portuguesa. 2a ed. (Revisada e Corrigida) Lisboa, Livraria Popular de Francisco Franco, [1959?].

LAUSBERG, Heinrich. Elementos de retórica literária. Lisboa, Fundação Calouste Gulbenkian, 2004.

LOURENÇO, Eduardo. “Tempo e poesia”. In Tempo e poesia. Lisboa: Gradiva, 2003. . "Fernando Pessoa ou o estrangeiro absoluto" e "Pessoa ou a realidade como ficção". In Poesia e metafísica. Lisboa, Gradiva, 2002.

MASSON, André. L'allégorie. Paris, Presses Universitaires de France, 1974.

MEYER, Augusto. "Le Bateau Ivre: análise e interpretação”. Textos críticos.Org. João Alexandre Barbosa. Editora Perspectiva, São Paulo, 1986. P 26- 68.

MOURA, Murilo Marcondes. Murilo Mendes: a poesia como totalidade. São Paulo: EDUSP, 1995.

OVÍDIO. As Metamorfoses. Trad. Paulo Framhouse Alberto. Lisboa, Livros Cotovia, 2007.

PAES, Octavio. Os filhos do barro: do romantismo à vanguarda. Trad. Ari Roitman e Paulina Wacht. São Paulo: Cosac \& Naify, 2013.

2012.

O arco e a lira. Trad. Ari Roitman e Paulina Wacht. São Paulo: Cosac \& Naify,

PAES, José Paulo. Armazém literário. São Paulo: Companhia das Letras, 2008.

POE, Edgar Allan. Poemas e Ensaios. Trad. Oscar Mendes e Milton Amado. $3^{\mathrm{a}} \mathrm{ed}$. Editora Global, 1999.

PREMINGER, Alex. BROGAN, T. The new Princeton encyclopedia of poetry and poetics. Princeton University Press, 1993.

RILKE, Rainer Maria. Cartas a um jovem poeta. / Canção de amor e de morte do portaestandarte Cristóvão Rilke. Trad. Paulo Rónai e Cecília Meireles. 24a ed.São Paulo: Globo, 1996.

Azul, 2013.

Elegias de Duíno. Trad. Dora Ferreira da Silva. 6 ed. São Paulo, Biblioteca

SAID, Edward. "Reflexões sobre o exílio". In Reflexões sobre o exílio e outros ensaios. São Paulo: Companhia das Letras, 2003. p.46-60. 
SCHILlER, F. Poesia ingênua e sentimental. Trad. Márcio Suzuki. São Paulo: Iluminuras, 1991.

SPITZER, L. Lingüística e história literária. Madrid: Credos, 1961.

STAROBINSKI, Jean. A melancolia diante do espelho: três leituras de Baudelaire. Trad. Samuel Titan Jr. São Paulo: Editara 34, 2014.

VALÉRY, Paul. O cemitério marinho. Trad. Jorge Wanderley. 2a Ed. Editora Max Limonad, São Paulo, 1984.

VILlAÇA, Alcides. Passos na poesia de Drummond. São Paulo: Cosac \& Naif, 2006. 